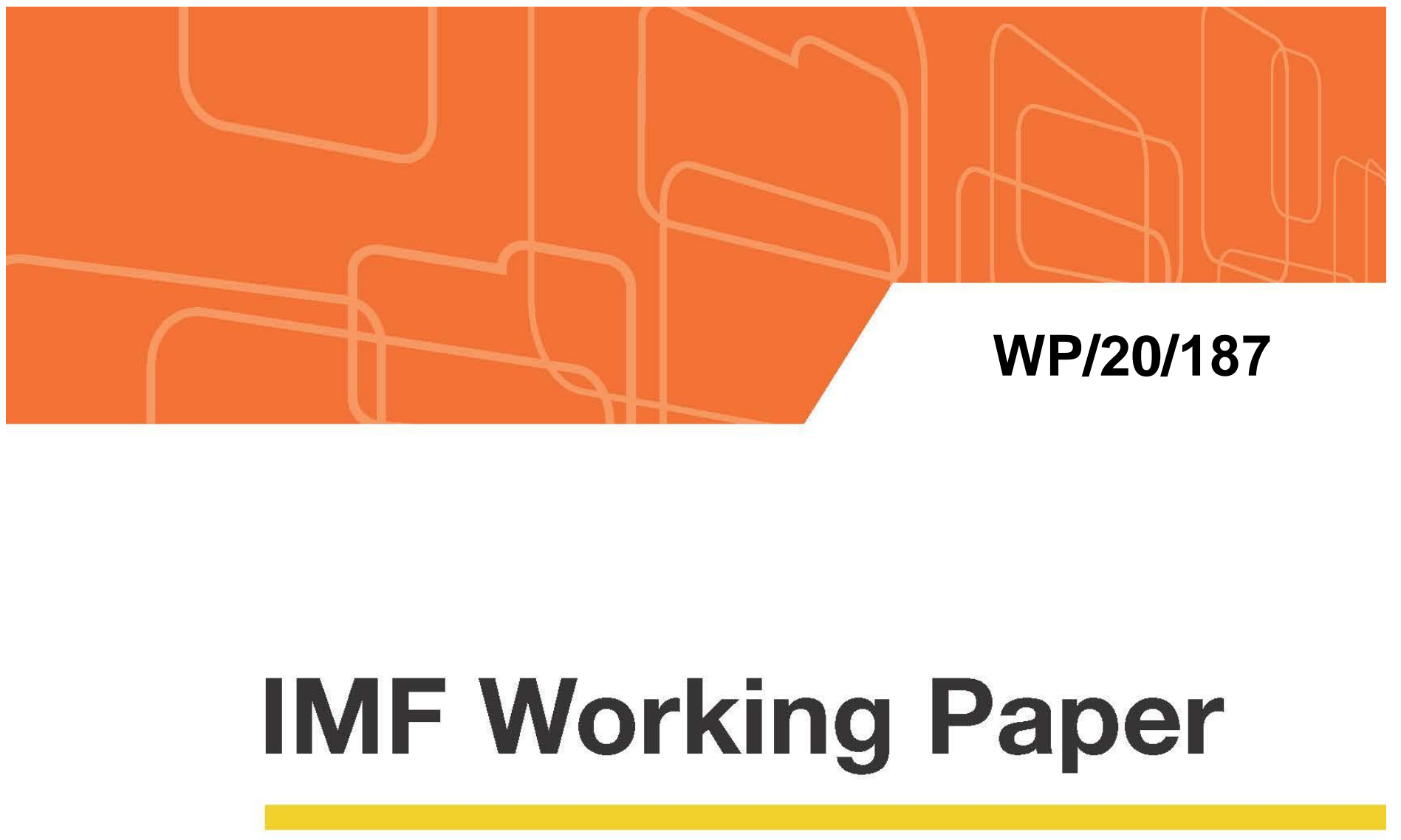

\title{
Exchange Rates and Domestic Credit- Can Macroprudential Policy Reduce the Link?
}

by Erlend Walter Nier, Thorvardur Tjoervi Olafsson, and Yuan Gao Rollinson

IMF Working Papers describe research in progress by the author(s) and are published to elicit comments and to encourage debate. The views expressed in IMF Working Papers are those of the author(s) and do not necessarily represent the views of the IMF, its Executive Board, or IMF management. 


\title{
IMF Working Paper
}

Monetary and Capital Markets Department

Exchange Rates and Domestic Credit—Can Macroprudential Policy Reduce the Link?

Prepared by Erlend Walter Nier, Thorvardur Tjoervi Olafsson, and Yuan Gao Rollinson

Authorized for distribution by Gaston Gelos

September 2020

IMF Working Papers describe research in progress by the author(s) and are published to elicit comments and to encourage debate. The views expressed in IMF Working Papers are those of the author(s) and do not necessarily represent the views of the IMF, its Executive Board, or IMF management.

\begin{abstract}
This paper examines empirically the role of macroprudential policy in addressing the effects of external shocks on financial stability. In a sample of 62 economies over the period of 2000: Q1-2016: Q4, our dynamic panel regressions show that an appreciation of the local exchange rate is associated with a subsequent increase in the domestic credit gap, while a prior tightening of macroprudential policies dampens this effect. These results are strong for small open economies, and robust when we explicitly account for potential simultaneity and reverse causality biases. We also examine a feedback effect where strong domestic credit pulls in additional cross-border funding, potentially further increasing systemic risk, and find that targeted capital controls can play a complementary role in alleviating this effect.
\end{abstract}

JEL Classification Numbers: E58, F32, F34, G28

Keywords: Macroprudential Policies, Capital Flows, Systemic Risk

Author's E-Mail Address: ENier@IMF.org, TOlafsson@IMF.org, monicagr@uw.edu 


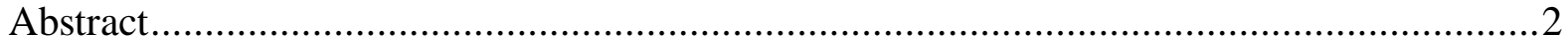

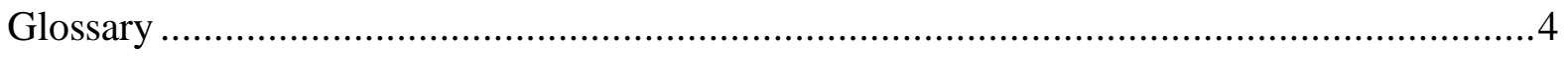

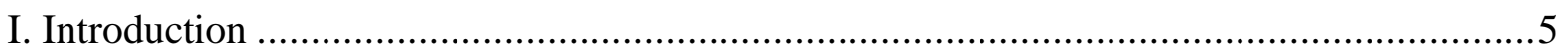

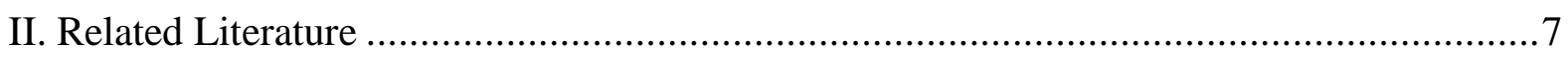

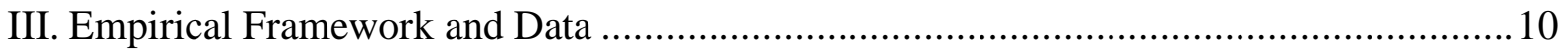

3.1 Baseline Setup and Methodology ....................................................10

3.2 Data and Variables .......................................................................... 12

3.3 Endogeneity of Macroprudential Policy ...............................................14

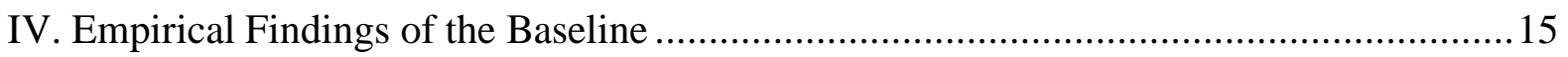

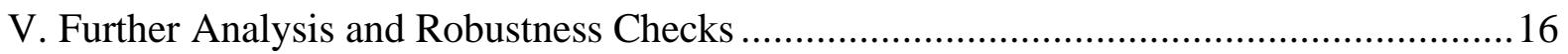

5.1 Using Actual Rather than Forecasted GDP Growth ...............................16

5.2 Distilling Exchange Rate Shocks....................................................... 17

5.3 Using Macroprudential Policy Shocks.................................................. 19

5.4 Effects of Macroprudential Policies by Country Characteristics ...........20

5.5 Alternative Measure of Domestic Credit Developments .......................21

VI. Extension: The Feedback Effect from Credit to Capital Inflows....................................22

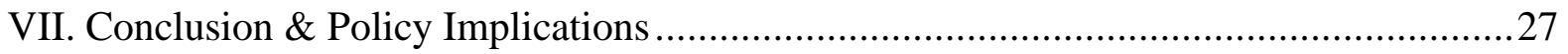

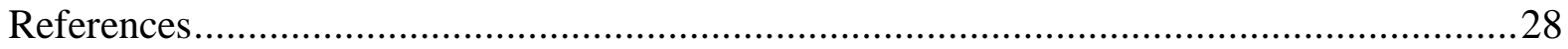

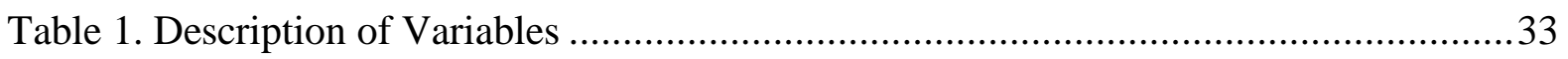

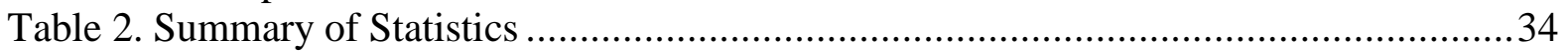

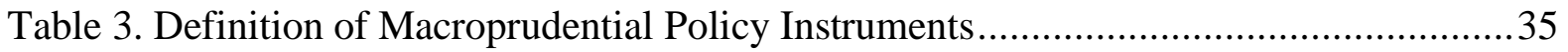

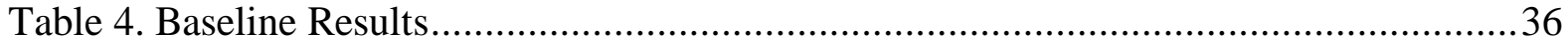

Table 5. Robustness - Results with Actual GDP Growth Rates.............................................3

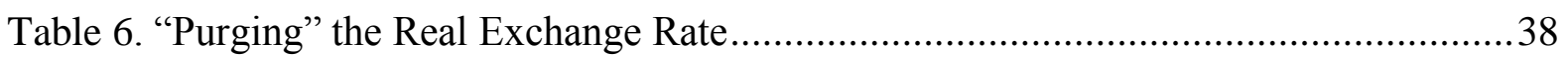

Table 7. Robustness - Results with "Purged" Exchange Rate Shocks ...................................39

Table 8. Results from Ordered Probit Regression ...................................................................39

Table 9. Robustness - Results with Macroprudential Policy Shocks .....................................39

Table 10. Effectiveness of Macroprudential Policies by Country Characteristics ..................42

Table 11. Robustness Check-Alternative and Simpler Measure of Credit Developments ...43

Table 12. Effectiveness of Macroprudential Policies by Individual Instrument .....................44

Table 13. Leakages and Capital Controls - the Random Effect Model .................................45

Table 14. Leakages and the "Gates" Effect of Capital Controls.............................................48

Figure 1. Exchange Rates, Credit, and Capital Flows ..............Error! Bookmark not defined. Figure 2. Credit-to-GDP Gap and Usage of iMaPP Actions ..............................................51

Figure 3. Numbers of Tightening and Loosening Macroprudential Policy Actions................52 


\section{GLOSSARY}

AE

BCBS

BIS

CPI

EME

FARI

FFA

FSB

FX

GDP

GMM

IFS

LSDV

MaPP

MaPP_Br

MaPP_FI

MPS

RER

RGDP

U.K.

U.S.

USD

$\mathrm{T} \& \mathrm{~L}$

WEO
Advanced Economy

Basel Committee on Banking Supervision

Bank for International Settlements

Consumer Price Index

Emerging Market Economy

Financial Accounts Restrictiveness Index

Financial Flows Analytics

Financial Stability Board

Foreign exchange

Gross Domestic Product

Generalized Method of Moments

International Financial Statistics

Least Square Dummy Variables

Macroprudential Policy Stance

Stance of Borrower-based Tools

Stance of Financial Institutions-based

Tools

Monetary Policy Stance

Real Exchange Rate

Real Gross Domestic Product

United Kingdom

United States

U.S. dollar

Tightening Actions Net of Loosening

Actions

World Economic Outlook 


\section{INTRODUCTION}

As is well-known, exchange rate movements are difficult to predict or even to explain ex post, and their interactions with other economic and financial variables continue to be subject to debate. A recently growing literature explores how movements in exchange rates not only affect macroeconomic outcomes, but can also affect financial conditions and credit developments (Blanchard et al., 2015, Shin 2018, Ghosh et al. 2018, Hofmann et al. 2019, Bank for International Settlements (BIS), 2019, Carstens, 2019), which may in turn feed back into the macroeconomic outlook. The main idea is that a currency appreciation would tend to ease domestic financial conditions, and this would boost the demand and supply of domestic credit. In this way, an appreciation may potentially be expansionary, in contrast to the standard notion in the earlier literature where an appreciation is held to be contractionary, by reducing net exports. Moreover, when an appreciation leads the domestic provision of credit to expand, this can contribute to systemic risk, and potentially require a policy response on the part of the macroprudential policymaker.

An appreciation of the local exchange rate can drive up domestic credit through a number of channels that may be at work at the same time and reinforce each other (see, e.g., Carstens, 2019). An exchange rate appreciation raises collateral values and net worth of domestic market participants and can then both increase borrowers' capacity to accumulate debt and ease lenders' constraints to provide it (Krugman, 1999; Céspedes et al., 2004; and Bruno and

Shin, 2015b). Currency appreciation can also lead to a lower perception of risk on the part of lenders, and an enhanced sense of prosperity on the part of borrowers (e.g., due to cheaper imported goods and services), thereby again increasing the demand and supply of credit. When increased credit in turn affects local asset prices, or is funded through borrowing from across the border, this can strengthen the ultimate effects of increases in exchange rates, potentially giving rise to a build-up of systemic risk (Gertler et al. 2007; Borio, 2014; Bruno and Shin 2015a,b; IMF 2017; and Baskaya et al. 2017).

In this paper we study the link between exchange rate movements and domestic credit in a panel of 62 countries over the period 2000 to 2016, and ask to what extent macroprudential policy can attenuate the effects of currency movements on domestic credit cycles (left-hand side of Figure 1). We also evaluate a complementary role of targeted controls on inflows, when strong developments in credit in turn lead to increases in cross-border borrowing by banks and corporate firms (right-hand side of Figure 1).

In this context, this paper makes three main contributions to the literature. First, we contribute to the recent empirical literature on the link between currency appreciation and domestic credit developments (Hofman and others 2019, Bruno and Shin, 2015a,b; Hahm et al., 2013; and Shin, 2018), by using the credit-to-GDP gap as a continuous indicator of the build-up of systemic risk. 


\section{Figure 1. Exchange Rates, Credit, and Capital Flows}

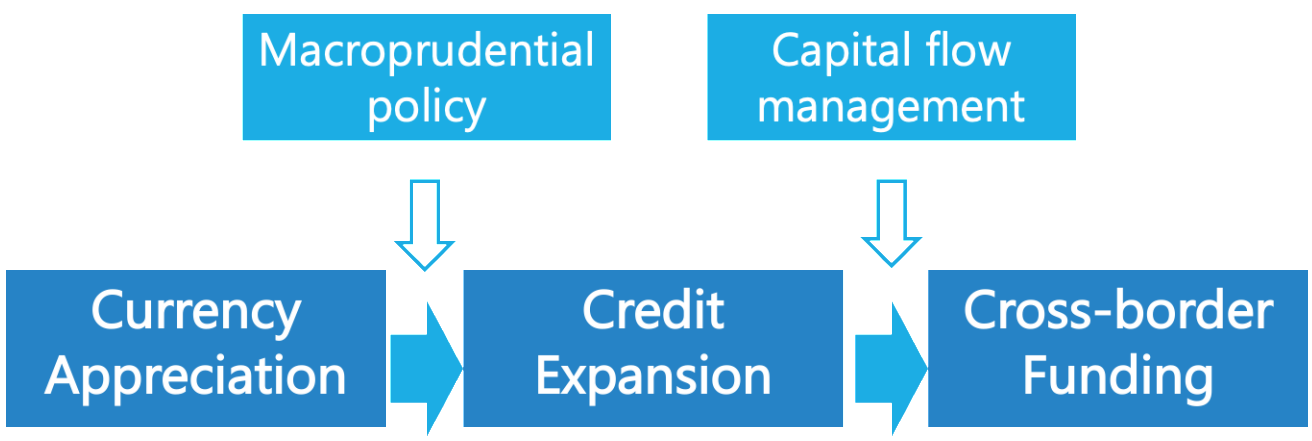

Source: Author's descriptions.

Second, we expand the literature on the effectiveness of macroprudential policy (Cerutti et al., 2017; Galati and Moessner, 2018, Alam et al., 2019), by examining the interaction effect of macroprudential policy in mitigating the impact of the exchange rate on domestic credit. This is important both from a policy perspective and from the point of view of improving the identification of the causal effects of macroprudential measures.

Finally, with regard to the literature on the relationship between capital flows and credit (Caballero, 2016, Mendoza and Terrones, 2012; Igan and Tan, 2017, Merrouche and Nier, 2017), and the effectiveness of capital controls (Ostry et al., 2011; Ghosh et al., 2018), we examine the complementary role of targeted capital controls when strong domestic credit pulls in cross-border funding and macroprudential policy faces leakages.

The empirical analysis in the main part of the paper examines the relationship between changes in real exchange rates and movements in the credit-to-GDP gap for 62 advanced and emerging market economies (AEs and EMEs, respectively) over the period 2000: Q12016: Q4. The main results are the following:

- $\quad$ First, exchange rate movements are associated with subsequent changes in domestic credit relative to GDP. In particular, an appreciation of the local exchange rate vis-àvis the United States (U.S.) dollar is followed by an increase in the credit-to-GDP gap in the next quarter.

- $\quad$ Second, macroprudential policy is found to have a direct effect on domestic credit developments. Where macroprudential policy is tightened, it leads to a reduction in the credit-to-GDP gap in the next quarter.

- $\quad$ Third, macroprudential policy weakens the extent to which exchange rate movements affect credit developments. When we interact changes to the exchange rate with changes in the macroprudential policy stance, we find that for a given appreciation of the real exchange rate, the subsequent increase in the credit-to-GDP gap is weaker where macroprudential policies had been tightened in the previous quarter. 
We find that our results are robust to a number of changes in the specification. First, we address potential simultaneity concerns that arise when some economic fundamentals might be driving both the exchange rate and credit developments. For this we apply a two-step procedure that involves "purging" the impact of domestic fundamentals on the real exchange rate and distilling more "exogenous" exchange rate shocks for use in our analysis. We find that our results continue to hold. Second, in order to address potential endogeneity of the macroprudential policy variable, we construct macropurdential policy shocks as the difference between the actual reading on the macroprudential indicator variable, and its expected value, based on prior developments in the credit gap and the exchange rate. Third, we find that results continue to hold when we move away from the credit gap and use an alternative and simpler measure of domestic credit developments.

In an extension, we proceed to examine a feedback effect from domestic credit developments to "other investment flows", which mainly capture cross-border loans and deposits received by financial institutions and the nonfinancial corporate sector. Controlling for global push factors, as well as other domestic pull factors, we find that increases in domestic credit are associated with increases in such flows. Moreover, where macroprudetial policy is tightened this leads to further increases in cross-border flows. We interpret this as evidence of policy leakage, where domestic corporates respond to macroprudential tightening by directly borrowing from abroad. On the other hand, targeted capital controls that aim to limit these types of flows appear to be effective. We find that where these controls are in place, this reduces the effect of credit developments in stimulating other investment flows, thereby limiting the further build-up of systmic risk from direct cross-border borrowing.

The remainder of this paper is organized as follows: Section II discusses how this research is related to the existing literature. Section III presents the empirical framework and the details of variables and data. Section IV discusses the baseline empirical findings. Section V reports on various further analyses and robustness checks. Section VI presents the extension on how domestic credit may fuel capital inflows. Section VII concludes and discusses some policy implications.

\section{RELATED LiteratuRE}

This paper links up four main strands of the literature: The first analyzes the linkage between currency appreciations and systemic risk, the second the effectiveness of macroprudential policies, the third the relation between capital flows and credit, and the fourth the effectiveness of capital controls.

An emerging literature has documented the link between currency appreciation and domestic credit (Blanchard et al, 2015, Bruno and Shin 2015a,b; Hahm et al., 2013; IMF 2017, Baskaya et al., 2017, Shin, 2018, Hofmann et al., 2019; and Carstens 2019). Building on a considerable body of earlier literature that had examined sudden stops (e.g., among many, 
Caballero and Krishnamurthy, 2004), these studies examine how a currency appreciation in the run-up to such events raises collateral values and net worth, and is also associated with a reduction in credit spreads, thereby encouraging market participants to take greater risks and allowing for an expansion in credit volumes (see, e.g., Hofmann et al., 2019). Indeed, parts of the literature have referred to these mechanisms as the "risk-taking channel" of currency appreciation in the context of cross-border spillovers of monetary policy (Bruno and Shin 2015a; Borio and Zhu 2012; and Hofmann, Shim, and Shin, 2019). Moreover, Gourinchas and Obstfeld (2012) find that a rapid increase in leverage and a sharp real appreciation of currency emerge consistently as the two most robust and significant predictors of financial crises. Our paper builds on this literature by documenting empirically a link between exchange rate movements and the credit-to-GDP gap, which is widely understood to be an early-warning indicator of a future financial crisis, in a large cross-country panel of 62 advanced and emerging economies. ${ }^{1}$

A second strand of literature that this paper relates to examines the effectiveness of macroprudential policies. These papers typically consider the effect of macroprudential policies on financial indicators that measure "excessive" financial risk, such as the growth in credit or asset prices. Lim et al. (2011) find that macroprudential policies are effective in reducing the procyclicality of credit and leverage in the banking sector. Vandenbussche et al. (2015) report a significant impact of macroprudential policies in reducing housing price inflation in 16 countries in the Central, Eastern, and Southeastern Europe region. A large number of studies find that macroprudential policy reduces the growth of credit (Claessens et al., 2013; Akinci and Olmstead-Rumsey 2018; Cerutti et al. 2017, and Alam et al 2019), while some studies also find evidence that such policies can reduce the incidence of credit booms (Mendoza and Terrones 2012), and lower the credit-to-GDP gap (Fendoğlu 2017, Lang and Welz 2018). Most studies find evidence supporting the notion that macroprudential policies can be effective in reducing systemic risks, with the evidence overall strongest for borrower-based macroprudential tools (such as caps on loan-to-value or debt-service to income) (Cerutti et al., 2017; Claessens et al., 2013; Fendoğlu 2017, Alam et al. 2019).

We build on this literature by examining the effectiveness of macroprudential policy in a large cross-country panel and focusing on the effects on the credit-to-GDP gap, which we take to be continuous indicator of the build-up of systemic risk. Our analysis of effectiveness deploys a novel database of macroprudential policy actions, the iMaPP database compiled by IMF staff from the Monetary and Capital Markets Department (Alam et al. 2019), which integrates a number of existing databases and is the most comprehensive of such databases to date, covering 17 instruments for a total of 138 countries since 1999. Moreover, our study differs from the existing literature in that we focus on the coefficients of the interaction terms of macroprudential policies and real exchange rate movement, so as to evaluate the effects of

\footnotetext{
${ }^{1}$ The credit-GDP gap was proposed by the Basel Committee as an early-warning indicator of financial crises (Basel Committee on Banking Supervision (BCBS) 2010; IMF-Financial Stability Board (FSB)-BIS 2016).
} 
macroprudential policies in mitigating the impact of real exchange rate on domestic credit developments. ${ }^{2}$

Third, this paper relates to the literature that has examined the relation between capital flows and credit. A large number of papers has found a positive association between "surges" of capital inflows and credit booms (e.g., Mendoza and Terrones, 2012, Elekdag and Wu, 2011), as well as between surges of capital inflows and subsequent banking crises (Caballero, 2016). Some studies highlight a tighter relation between particular types of inflows and credit developments (Bruno and Shin 2015b; Bruno and Shin 2015a; Hahm et al., 2013; IMF 2017; Igan and Tan, 2017, and Baskaya et al., 2017), and commonly find that "other investment inflows" (which is mainly deposits and loans received by banks and corporates) have the most robust positive correlation with domestic credit growth (IMF, 2017; Igan and Tan, 2017).

Most discussions focus on a causal link that runs from capital inflows to credit, where capital inflows lead to an increase in loanable funds for the domestic banking system, and thereby "push up" the supply of domestic credit. However, many studies acknowledge that there is likely to be a two-way relationship, where strong domestic credit can also "pull-in" additional capital from abroad (Igan and Tan, 2017, Amri, Richey and Willet, 2016, Lane and McQuade, 2014). For instance, a domestic (demand or supply) shock may generate rapid credit growth, which in turn fuels sentiment, boosts asset prices and pulls in international capital (Igan and Tan, 2017, Caballero, 2016).

A feedback effect running from credit demand to capital inflows may be strong in particular for "other investment flows," including direct-cross border borrowing by corporates and cross-border funding of the banking system (Borio, McCauley and McGuire, 2011, Avdjiev, Mc Cauley and McGuire, 2012, and Hahm et al., 2013). When the growth in credit outruns the growth in domestic deposits, this can lead corporates to borrow directly from abroad (increasing direct cross-border credit), and lead banks to tap international markets to complement domestic deposit funding by wholesale funding (indirect cross-border credit).

This feedback effect is closely linked to the phenomenon of the cross-border leakage of macroprudential policy, where if policymakers put constraints on domestic lending, this may lead to increased provision of credit from abroad (e.g., Ahnert et al. 2018, Reinhardt and Sowerbutts 2015). We therefore embed our analysis of leakages of macroprudential measures in an empirical framework that focuses on the feedback effect from credit to increases in "other investment inflows."

\footnotetext{
${ }^{2}$ This complements a study by Fendoğlu (2017), which examines the effectiveness of macroprudential policy (including capital flow management-related macroprudential measures) in mitigating the impact of capital inflows on the credit-toGDP gap.
} 
Our paper relates finally to a growing literature that investigates the effectiveness of capital flow management measures and other policies in managing risks from capital inflows (e.g., Cerutti and Zhou, 2018, Ostry et al. 2011, Forbes et al. 2014). Bruno et al. (2017) find that capital flow management policies in the banking sector and bond market are effective in slowing down banking inflows and bond inflows, respectively. Klein (2012) examines the association of capital inflows controls on financial variables and distinguishes between the effect of long-standing controls and episodic controls, reporting findings that suggest longstanding controls ("walls") may be more effective than episodic controls ("gates"). In our extension we examine the effect of both macroprudential policy and targeted capital controls on "other investment flows," and explore whether these policies can affect the degree to which strong domestic credit pulls in cross-border funding.

\section{EMPIRICAL FRAMEWORK AND DATA}

\subsection{Baseline Setup and Methodology}

In the main part of the paper we use a dynamic panel framework to investigate the determinants of the credit gap. Our baseline set-up, which we expand on in further analysis, relates the credit gap (denoted $Y$ ) to changes in the real exchange rate, macroprudential policy actions, their interactions, as well as controls:

$$
\begin{aligned}
& \boldsymbol{Y}_{i, t}=\rho \boldsymbol{Y}_{i, t-1}+\beta_{1} \Delta^{4} \boldsymbol{R E} \boldsymbol{R}_{i, t-1}+\beta_{2} \boldsymbol{M a P P}_{i, t-1}+\beta_{3} \boldsymbol{M a P P}_{i, t-1} \times \Delta^{4} \boldsymbol{R E} \boldsymbol{R}_{i, t-1}+\theta \boldsymbol{Z}_{i, t-1}+\mu_{i}+v_{i, t} \\
& \text { where } E\left[\mu_{i}\right]=E\left[v_{i, t}\right]=E\left[\mu_{i} v_{i, t}\right]=0 \\
& \text { control variables } Z_{i, t-1}=\left[M P S_{i, t-1}, \Delta^{4} F_{-} R G D P_{i, t-1}\right]
\end{aligned}
$$

The subscripts $i$ and $t$ represent country and time (quarter) respectively; $\mu_{i}$ is a fixed effect that captures time-invariant country characteristics, and $v_{i, t}$ is the error term. ${ }^{3} \Delta^{4} R E R_{i, t-1}$ is the year-over-year log change of real exchange rate, which is lagged by one quarter.

$M a P P_{i, t-1}$ is an ordinal indicator variable representing the number of macroprudential policy actions by direction (tightening actions net of loosening actions) that are taken during period $\mathrm{t}-1$ in country $i$. In addition to this measure, we analyze the effects of tightening ( $T_{-} M a P P$ ) and loosening (L_MaPP) actions separately.

$Z_{i, t-1}$ is a vector of control variables, which includes the monetary policy stance (MPS) and forecasted year-over-year real GDP growth $\left(\Delta^{4} F_{-} R G D P\right)$, both again lagged by one quarter.

\footnotetext{
${ }^{3}$ The quarterly time-fixed effect, a proxy of the exogenous global push factor, is not considered here. First, potential collinearity arises when the global push factor also affects the domestic drivers of credit developments. Indeed, the inclusion of time-fixed effect makes most coefficients of the domestic drivers statistically insignificant. Second, its inclusion violates the assumption of first order serial correlation in residuals for the dynamic panel model (e.g., p-values of AR(1) test range from 0.35 to 0.9 ).
} 
In contrast to the approach in the existing literature (e.g., Claessens et al., 2013; Akinci and Olmstead-Rumsey 2018; Cerutti et al. 2017, and Alam et al 2019), we use the forecasted GDP growth rates rather than the more widely used actual GDP growth rates to mitigate a potential simultaneity concerns stemming from both credit and the exchange rate being driven by good news about the economy. By including the growth forecast, we measure the effect of the residual variation in the exchange rate that is orthogonal to these effects.

The aggregate measure $M a P P_{i, t-1}$ is a lagged ordinal indicator variable representing the number of macroprudential policy actions by direction (tightening actions net of loosening actions) which are taken during period $t-1$ in country $i$. For example, a value of $+3(-3)$ represents three policy actions being taken to tighten (loosen) the macroprudential policy stance within the quarter, and a value of 0 represents no action is taken within the quarter.

If macroprudential action has the effect of reducing the credit gap, we would expect $\beta_{2}<0$ in the equation above. Moreover, by construction, a negative change in $\Delta^{4} R E R$ represents a real exchange rate appreciation. If an appreciation is associated with an increase in the credit gap, we would therefore expect $\beta_{1}<0$.

A key focus of our investigation is the interaction between macroprudential action and the change in the real exchange rate $M a P P_{i, t-1} \times \Delta^{4} R E R_{i, t-1}$. If macroprudential action is effective in containing the impact of the real exchange rate appreciation on the credit gap, we expect $\beta_{3}>0$, with this effect thereby attenuating the negative coefficient on the real exchange rate.

We estimate the above equation using the Generalized Method of Moments (GMM) estimator developed by Arellano and Bond (1991), to address endogeneity concerns and avoid the Nickell bias ${ }^{4}$ arising in the presence of the lagged dependent variable. In addition, we verify that the Arellano-Bond approach is suitable for our purposes since all further conditions on its use are found to hold. ${ }^{5}$

\footnotetext{
${ }^{4}$ The bias of the Least Square Dummy Variables (LSDV) estimator in a dynamic model is generally known as dynamic panel bias or Nickell's bias (Nickell, 1981). If the lagged dependent variable appears as an independent variable, strict exogeneity of the regressors no longer holds. The LSDV is no longer consistent when $\mathrm{N}$ tends to infinity and $\mathrm{T}$ is fixed. Given our sample period $\mathrm{T}=68$, the theoretical semi-asymptotic bias (assuming $\mathrm{N} \rightarrow \infty$ ) is -0.0391 in the baseline for an autoregressive coefficient of 0.98 . The actual bias is supposed to be slightly larger for the $\mathrm{N}=62$ in our sample. Moreover, a smearing effect arises from the endogeneity (the inconsistency of other independent variables due to the endogeneity of the one variable is smeared across all of the least squares estimators), and a large degree of autocorrelation further magnifies the inconsistency (Kiviet 1995).

${ }^{5}$ In addition to the Nickell bias arising in the presence of the lagged dependent variable $Y_{t-1}$, these are that the independent variables are not strictly exogenous and are correlated with past errors; a statistically significant linear functional relationship holds, which is confirmed by our baseline result; there is unobserved crosssectional heterogeneity in the credit gap (denoted as $\mu_{i}$ ); there is autocorrelation within individual panel's error terms $\vartheta_{i, t}$, which is verified by a AR(1) test in the baseline result (Roodman, 2009).
} 
We lag the MaPP variable by one-quarter, which is consistent with the approach in the previous literature (Akinci and Olmstead-Rumsey 2018; Cerutti et al., 2017; Fendoğlu 2017). We finally lag the real exchange rate, as well as all other independent and control variables to mitigate endogeneity concerns.

In our estimation, the first-differenced lagged dependent variable is instrumented with its 1-3 lags of its level. All independent and control variables are treated as predetermined rather than strictly exogenous. ${ }^{6}$ We use the forward orthogonal deviation transformation (Arellano and Bover 1995) to mitigate data gap issues in unbalanced panels. We also use two-step covariance estimates to obtain robust standard errors and to correct their downward bias (Windmeijer 2005).

\subsection{Data and Variables}

Our sample includes 62 economies ( 35 AEs plus 27 EMEs) as shown in Figure 2. These economies have sufficiently good data at quarterly frequency, not just on macroprudential policy measures, but also on credit and GDP. The sample covers economies that have taken frequent macroprudential policy actions (e.g., India, Korea, and Russia) and those that have rarely done so (e.g., Chile, Germany, and the United States). The sample period spans from 2000: Q1 to 2016: Q4, as macroprudential policy has been increasingly used across countries since the early 2000. To remove the effect of outliers, we winsorize the top and bottom 1 percent observations of each variable except the dependent variable and the ordinal variable MaPP. See Table 1 for description of variables, and Table 2 for summary of statistics.

Dependent variable $(Y)$ : Our domestic credit measure is the credit-to-GDP gap, which is the quarterly credit-to-GDP ratio relative to its long-run trend. Following the method proposed by the BCBS (2010), we calculate the gap from a one-sided HP filter using a long-run smoothing parameter $\lambda=400,000^{7}$. Credit is broadly defined in this paper as total claims on the private non-financial sector from both banks and non-bank financial institutions to capture all domestic sources of debt funds for the private sector. ${ }^{8}$ We use the financial corporations' domestic claims on private sector from the IMF's International Financial Statistics (IFS) database where available, otherwise, we use depository corporations` (or monetary) domestic claims on the private sector from the same source. For brevity, we refer

\footnotetext{
${ }^{6}$ Predetermined is a weaker restriction than strict exogeneity. The underlying assumption is the current period error term is uncorrelated with current and lagged values of the predetermined variable but maybe correlated with future values.

${ }^{7}$ Initially taking the first 24 quarters, then computing the trend and cyclical components recursively (adding one quarter at a time).

${ }^{8}$ The credit data are not fully harmonized across countries as sometimes they are from surveys reported by different entities within a country. For instance, the credit data for Iceland and Taiwan POC are from the central banks. Allowing this heterogeneity is the only way to provide a sufficient sample coverage across country and time for our study.
} 
the credit-to-GDP gap as "credit gap" in the rest of this paper. We consider the simpler 4-quarter change of the credit-to-GDP ratio in a robustness check.

Forecasted YoY growth of real GDP $\left(\Delta^{4} F_{-} R G D P\right)$ : We include the consensus forecast of future GDP growth as a control, since this serves to mitigate a potential simultaneity problem, when "good news" about the economy leads the exchange rate to appreciate and at the same time stimulates credit. We construct the forecasted quarterly year-over-year real GDP growth by taking a weighted average of the current year's and next year's forecasted growth rates from the Consensus Forecast. ${ }^{9}$ For five countries (Iceland, Lebanon, Luxembourg, Malta, and Mongolia) for which consensus forecasts are not available, we apply the same weighted average method but use the realized forward growth rates instead as a "perfect foresight" measure. Optimism with respect to short-run economic outcomes is expected to drive up both credit demand and supply, so a positive coefficient is expected. We use the actual GDP growth rates in a robustness check.

Monetary policy stance (MPS): We use (lagged) central bank policy rates to capture the monetary policy stance. For countries that have implemented unconventional monetary policies during the sample period (Euro Area, U.S., U.K., and Japan), we use the so-called shadow policy rates estimated by Krippner (2016). As a monetary policy tightening is generally found to reduce aggregate demand and increase the cost of borrowing, we expect a negative coefficient.

YoY change of real exchange rate $\left(\Delta^{4} R E R\right)$ : We use the (lagged) year-over-year log change of the weighted average of the bilateral nominal exchange rate prevailing over the past four quarters $^{10}$, which is denoted in national currency relative to the USD, and deflated by the U.S. consumer price index (CPI) against domestic CPI. An appreciating real exchange rate can fuel the build-up in credit through multiple channels as described in section I. By convention, a negative change in $\Delta^{4} R E R$ represents a real exchange rate appreciation, so we expect a negative coefficient.

Macroprudential policy stance (MaPP): The data source for macroprudential policy actions is the IMF's iMaPP database (Alam et al., 2019), which is, to the best of our knowledge, the most comprehensive database of macroprudential policies to date (covering 17 instruments for a total of 138 counties over the period 1999-2016 at a monthly frequency). We consider an aggregate measure of the macroprudential policy stance ( $M a P P)$ as well as two

\footnotetext{
${ }^{9}$ The first quarter carries full weight of the forecasted real GDP growth of current year, based on the forecast in January; the second quarter gives $3 / 4$ weight to the current year and $1 / 4$ weight to the next year, based on the forecast in April; the third quarter gives equal weights to the current year and next year, based on the forecast in July; the fourth quarter carries full weight of the next year, based on the forecast in October.

${ }^{10}$ The weighted average of variable $\mathrm{X}$ is calculated as $\mathrm{X} \_\mathrm{WA}=0.4 * \mathrm{X}+0.3 * \mathrm{~L} 1 . \mathrm{X}+0.2 * \mathrm{~L} 2 . \mathrm{X}+0.1 * \mathrm{~L} 4 . \mathrm{X}$. We also use the simple average and the true year-over-year log change of real exchange rate, and found results to be consistent with using the weighted average (while the significance level and size of coefficients slightly dropped).
} 
subgroups: borrower-based tools $\left(\mathrm{MaPP} \_\mathrm{Br}\right)$ and financial institutions-based tools $\left(M a P P_{-} F I\right)$. Moreover, the iMaPP database allows us to distinguish policy adjustments that amount to a tightening and those that lead to a loosening of macroprudential constraints. Details of the individual macroprudential instruments covered in each subgroup are available in Table 3 and Figure 3.

\subsection{Endogeneity of Macroprudential Policy}

A common challenge faced by the literature on the effects of macroprudential policy is the problem of endogeneity, and more specifically that of potential reverse causality (Galati and Moessner, 2018; Alam et al., 2019). Macroprudential policy actions are not taken in a vacuum, but may be taken in response to macroeconomic and financial developments, which may be the same variables used to assess their effects. In our context, when we want to assess the effect of the policy action on the credit gap, but the credit gap is used as a signal for policy actions by policymakers, this can result in reverse causality. When high values of the credit gap are likely to result in tightening, this could induce a positive correlation that would bias the estimates on the impact, which are expected negative, up towards zero (attenuation bias).

We mitigate the risk of biased estimates due to endogeneity in four ways (with the first two ways being commonly applied in the literature (e.g., Claessens et al. 2013, Cerutti et al., 2017)):

- In our baseline set up, we lag the macroprudential indicator and control variables by one-quarter and also include the lagged dependent variable;

- We use the Arellano-Bond difference GMM methodology, which is suitable for independent variables that are not strictly exogenous;

- We focus on the interaction term of $M a P P_{i, t-1} \times \Delta^{4} R E R_{i, t-1}$. This should suffer less from an endogeneity bias, on the assumption that changes to exchange rates are not commonly taken into consideration when setting macroprudential policy. The change in the exchange rate then functions as exogenous shifter of the effect of prior macroprudential action, reducing the potential endogeneity problem; ${ }^{11}$ and

- $\quad$ Finally, in further analysis (presented in section V), we construct macroprudential policy shocks, by taking the difference between the actual macroprudential indicator and its expectation, conditional on development in the credit gap, as well as the exchange rate. The advantage of this approach is that, by construction, these shocks are orthogonal both to the credit gap and the change in the exchange rate.

\footnotetext{
11 This reasoning is in line with recent econometric theory developed by Bun and Harrison (2019). These authors study inference in models in which there is both an endogenous (x) and an exogenous explanatory variable $(\mathrm{w})$. Their analysis shows that, under fairly general conditions, the interaction term between $\mathrm{x}$ and $\mathrm{w}$ can be identified consistently using OLS, even if it is difficult to find valid instruments for the base effect of $x$ on $\mathrm{y}$, and the OLS estimator of this effect is inconsistent.
} 


\section{EMPIRICAL FINDINGS OF THE BASELINE}

Table 4 presents the baseline regression results on the effects of the exchange rate and macroprudential policy on the credit gap.

We show results for the aggregated index of macroprudential policy action, which includes all measures $(i M a P P)$ and two subgroups of macroprudential policy tools, the borrowerbased tools, $M a P P_{-} B r$, and the financial institutions-based tools, $M a P P_{-} F I$. The first two columns shown for each group are based on a measure of net tightening (tightening actions net of loosening actions); and the last two columns of each group separate the tightening (T) and loosening actions (L). We emphasize four results:

First, exchange rate movements have a measurable effect on domestic credit developments (column 1). In particular, a 10 percent real exchange rate appreciation is associated with a subsequent increase in the credit gap of 0.5 percentage points of GDP. This is on the same order of magnitude as the median credit gap in the sample ( 0.33 percent of GDP) and therefore economically meaningful. The size of the effect turns out to be robust across different specifications (with the size of the effect measured as between 0.5-0.6 percentage points) and statistically highly significant (typically at the 1 per cent level).

Second, macroprudential policy has a direct effect on domestic credit developments. In particular, a net tightening of macroprudential policy is estimated to decrease the credit gap by 0.875 percentage points of GDP in the next quarter, which again exceeds the median and is roughly 0.08 of the standard deviation of the credit gap. Looking at different groups of macroprudential policy, the effect is stronger for borrower-based than financial institutionsbased tools (columns 5 and 9), in line with prior literature. Considering tightening and loosening actions separately (column 3), the effect is strong and significant for tightening actions (1.168 percentage points of GDP) but insignificant for loosing actions.

Third, in addition to having a direct impact on the credit gap, macroprudential policy has the effect of weakening the extent to which exchange rate movements impact credit developments. This effect is reflected in the coefficient of the interactions term $M a P P_{i, t-1} \times \Delta^{4} R E R_{i, t-1}$ which shows a strong and statistically significant effect of macroprudential policy in mitigating the effect of the exchange rate on the credit gap. This mitigating effect holds for both the aggregated and the two subgroups of macroprudential policy, that is for both borrower-based and financial institutions-based policies. In economic terms, a one standard deviation increase in $i M a P P$ is estimated to reduce the sensitivity of the credit gap to real exchange rate movements by 0.82 percentage points of GDP. This effect is again stronger for the borrower-based tools, with a one standard deviation increase in such tools being estimated to reduce the sensitivity of the credit gap to the real exchange rate by 1.4 percentage points of GDP, compared with 0.9 percentage points of GDP for the financial institutions-based tools. 
Fourth, we find evidence that a prior relaxation of macroprudential policy can have a strong and significant effect in increasing the extent to which an exchange rate shock affects the credit gap. This is evident from looking at the interaction terms for tightening and loosing actions separately (column 4). Columns 8 and 12 reveal that this effects appears to be driven by loosening of financial institutions-based tools rather than borrower-based ones.

As for the control variables, the estimated coefficients have the expected sign and are highly significant: A one percentage point tightening of monetary policy is estimated to reduce the credit gap by about $0.24-0.29$ percentage points of GDP, while expectations of improved macroeconomic conditions increase the credit gap, with a one percent improvement in annual forecasted real GDP growth leading to an increase of the credit gap by about $0.45-0.5$ percentage points of GDP.

The coefficients of the lagged dependent variable appear close to unity, but the Fisher-type panel unit root test confirms that the credit gap variable is stationary (in at least one panel). ${ }^{12}$ Also, the large autoregressive coefficient is partially due to the setting of forward orthogonal deviation transformation in the GMM estimation.

Furthermore, the instrument lag choice is validated by the p-value of $\operatorname{AR}(1)$ and $\operatorname{AR}(2)$ at the bottom of Table 4. Result yields small p-values of AR(1) about 2 percent, so the null hypothesis of no first order autocorrelation in first differences is rejected as expected. The instrument lag choice yields all AR(2) p-values above the 10 percent threshold (ranging from 23-37 percent ), so the null hypothesis of no first order autocorrelation in levels $(\operatorname{AR}(2))$ is not rejected, suggesting the second lags are appropriate instruments for their current values.

\section{FURTHER ANALYSIS AND RobUSTnESS CHECKS}

We perform a number of further analysis and tests in order to examine more deeply the relationships identified in the main results and to assess their robustness. These findings are presented in Tables 5-12.

\subsection{Using Actual Rather than Forecasted GDP Growth}

In the baseline result of Table 4, we control for the impact of the forecasted real GDP growth on domestic credit development. In this section, we replace the forecasted growth rates with the realized growth rates, i.e., the (lagged) year-over-year log change of quarterly real GDP from the IMF World Economic Outlook (WEO) database $\left(\Delta^{4} R G D P\right)$. Actual GDP growth rates are more commonly used in the existing literature (Fendoğlu 2017; Cerutti, Claessens, and Laeven 2017). However, they may, in the context of our exercises, be inferior as a

\footnotetext{
${ }^{12}$ See Phillips and Moon (2000) for their review of recent econometric methods of panel unit root tests and their discussion on the inadequacy of those tests.
} 
control for potential simultaneity issues that arise when both credit and the exchange rate changes are being driven by economic expectations, e.g., related to good news about economic prospects.

Overall, results presented in Table 5 are consistent with Table 4. However, they also suggest that GDP forecasts are a much stronger control than past realizations of GDP. While the coefficient of $\Delta^{4} R G D P$ is positive and statistically significant, as was found in other studies, the size of the coefficient is only about a half of that for the GDP forecast: a one percent increase in the actual real GDP growth rates leads to an increase of the credit gap by about 0.24-0.29 percentage points of GDP, compared with about $0.45-0.5$ percentage points of GDP for the forecasted real GDP growth. This suggests that the evolution of credit gaps is more closely related to the expectation of future growth than to past growth in GDP. Moreover, and by contrast, the coefficient on the real exchange rate movement is somewhat larger when we use actual GDP compared to when we use the growth forecast, consistent with the idea that the larger coefficient is capturing some of the "good" news effects we control for when using forecast GDP. The coefficient of the interactions term $M a P P_{i, t-1} \times \Delta^{4} R E R_{i, t-1}$, on the other hand, roughly remain with the same magnitudes and levels of significance.

\subsection{Distilling Exchange Rate Shocks}

We take our examination of potential simultaneity one step further by accounting more fully for economic fundamentals that may simultaneously be driving both the real exchange rate and credit developments. For instance, it is conceivable that, in addition to growth expectations, inflation and current account developments affect the exchange rate, and these might also affect the credit gap. This would result in a simultaneity bias in that the coefficient on the exchange rate would reflect both the causal effect and the correlation induced through this simultaneity, thereby overstating the former. While this need not be the case, this bias could conceivably then also affect the interaction term between the exchange rate and macroprudential policy.

To address this concern, we attempt to distill more "exogenous" exchange rate shocks for use in our main regressions. The proposed two-stage procedure we use here is similar in spirit to those used in Auerbach and Gorodnichenko (2013) for fiscal policy, Furceri et al. (2016) for monetary policy, and Ahnert et al. (2018) for macroprudential policy: First, we "purge" the impact of domestic fundamental factors on the real exchange rate by running a fixed-effect regression of the exchange rate on those domestic fundamentals ${ }^{13}$, and in the second stage we use the residuals from this regression to replace $\Delta^{4} R E R_{i, t-1}$ in our baseline dynamic panel

\footnotetext{
${ }^{13}$ Results of the second stage regressions are robust given different combination of domestic fundamental variables considered in the first stage (we have also tried the quarterly change of domestic demand), and they all yield very low explanatory power in the first stage fixed-effect regression (overall R-square less than 0.05).
} 
regression with those (lagged) "purged shocks". The first stage regressions have the following forms:

$$
\Delta^{4} \boldsymbol{R E R} \boldsymbol{R}_{i, t}=\beta_{1} \Delta^{4} \text { Inflation }_{i, t}+\beta_{2} \Delta^{4} \boldsymbol{F}_{-} \boldsymbol{R G D P}_{i, t}+\beta_{3} \Delta^{4} \boldsymbol{C A}_{-} \text {Deficit }_{i, t}+\eta_{i}+e_{i, t}
$$

Where $\Delta^{4}$ inflation is the year-over-year change of the CPI, $\Delta^{4} F \_R G D P$ is the forecasted real GDP growth, and $\Delta^{\mathbf{4}} C A_{-}$Deficit is the year-over-year change in the current account deficit (positive values entail a greater deficit while negative values a move towards surplus). Data availability means that the size of the sample is slightly reduced from 62 to 60 economies when the current account variable is included in the first-stage regression.

Table 6 shows the results of the first stage. Unsurprisingly, while individual coefficients on some of the fundamentals come out significant, the overall explanatory power of the firststage regressions is low (R-square is about 0.04), in line with the well-known notion that exchange rate movements are difficult to explain, and are therefore to a considerable extent "random" (Rossi, 2013). On the other hand we find that both growth forecasts and inflation developments individually are significant in explaining movements in exchange rates, with the effect of the GDP forecast overall the strongest.

Table 7 shows the results of the second stage, using the residuals obtained from the firststage regressions. This shows that, while there is a very slight drop in the size of the coefficient on the exchange rate, relative to the baseline, the results on this effect continue to hold strongly. Moreover, the ability of macroprudential policy to affect the credit gap directly and indirectly, by reducing the impact of the exchange rate shocks on credit, continues to hold. Finally, we when we include inflation and changes in the current account in the main regressions these variables are not significant in affecting the credit gap, and the results on other variables are mainly unchanged (results not shown).

In addition, we have attempted to instrument the domestic real exchange rate fluctuations in the baseline regression using a standard instrumental variable approach, with potential instruments in the first stage regression including time fixed effects, average changes in real exchange rates against the dollar in countries within the same region, as well as changes in commodity prices from Gruss and Kebhaj (2019). However, the results throughout suffer from a "weak instruments" problem, in that the correlation of the predicted values with the actual change in real exchange rates is low, then reducing also the correlation with credit developments that we investigate in the second stage. We take away from these exercises that idiosyncratic variation in exchange rate movements account for an important part of the comovement between exchange rates and the credit gap.

Overall, we conclude that it is important to control for potential simultaneity in our context, and that including GDP forecasts in the specification is already a quite powerful way of doing so. Constructing more explicit exchange rate shocks can also be useful, but does not 
lead to major changes in the estimates when comparted to a baseline that already controls for growth expectations. Finally, we find that idiosyncratic variation in exchange rate movements account for an important part of the co-movement between exchange rates and the credit gap.

\subsection{Using Macroprudential Policy Shocks}

As set out above, a common concern when estimating the effects of macroprudential policy on credit is the reverse causality that arises when macroprudential policy is not random, but reacts to credit developments. When we want to measure the effects of policy action on credit developments, this can lead the estimated coefficients to be biased towards zero the so-called attenuation bias (see also Alam and others, 2019). While our baseline regression already attempts to mitigate this bias, by using the lag of the macroprudential indicator, we here go a step further, by using macroprudential policy "shocks."

Specifically, the identification of macroprudential policy shocks follows a three-step method closely following Brandao-Marques and others (2020), and related again also to the literature that computes policy shocks for monetary (Furceri et al., 2016) and fiscal policy (Auerbach and Gorodnichenko, 2013):

- $\quad$ Step 1: we estimate an ordered probit model of the macroprudential policy indicator variable $^{14}$ conditional on observables. As independent variables we use the year-overyear change of the quarterly credit-to-GDP gap, the change of the real exchange rate ( $\Delta^{4} R E R$ as used in the baseline), the quarterly change of net capital inflows (as percent of GDP), an indicator of lagged policy actions (the sum of lags one to four of the quarterly macroprudential policy indicator), and a country indicator to capture cross-sectional heterogeneity. The ordered-probit (first stage regression) is shown in Table 8.

- Step 2: we compute the "expected" macroprudential policy stance using the probabilities obtained from the ordered probit regression conditional on the independent variables.

- $\quad$ Step 3: we compute the macroprudential policy shocks as the actual macroprudential indicators minus their expected values. Thus, positive values represent tightening shocks and negative values represent loosening shocks.

By construction, the shocks are orthogonal to credit developments, as measured by the past changes in the credit gap, helping to reduce endogeneity. In addition, importantly, they are orthogonal to exchange rate changes, thereby mitigating concerns that macroprudential policy might respond to exchange rate movements.

\footnotetext{
${ }^{14}$ For this exercise we recategorize the macroprudential indicator into five outcomes: tightening by two or more actions (+2), tightening by one action (+1), no change (0), loosening by one action $(-1)$, or loosening by two or more actions $(-2)$. We then use an ordered probit that accounts for these five buckets.
} 
When we replace the variable $M a P P_{i, t-1}$ in the baseline regression with the macroprudential policy shocks identified above $\left(M P_{P} P_{-} S_{h o c k} k_{i, t-1}\right)$, the estimation result, shown in Table 9, is roughly consistent with the baseline. In particular, all interaction terms are essentially the same. However, at the margin we find that the base effects of macroprudential action are measured larger and more significant compared to the baseline. This holds in particular for the coefficients on the aggregate indicator and the financial institutions-based indicator, suggesting that these coefficients are measured with less bias when using the shocks.

When inspecting the first-step regressions (Table 8), consistent with this, we find that the coefficient on the change in the credit gap is sizable and statistically significant at the five and one per cent levels in the regressions explaining the overall and financial-institutionsbased indicators, respectively, while the credit gap is not significant in the regressions explaining the use of borrower-based tools. This suggests that the former actions respond more strongly to credit developments, relative to the borrower-based tools, creating a greater potential for attenuation bias in the measurement of policy effects. As regards the first-step results, it is worth noting also that the change in the exchange rate does not enter statistically significant in any of the regressions, in line with our prior that macroprudential policy does not tend to react to movements in the exchange rate.

Overall, we find that when using macroprudential policy shocks, the attenuation bias from reserve causality is reduced. This affects mainly the base effect of macroprudential policy, and in particular the financial-institutions-based tools while interactions of all types of tools with the change in the exchange rate are not affected substantially when using macroprudential policy shocks in place of the indicator we have in the baseline.

\subsection{Effects of Macroprudential Policies by Country Characteristics}

We next examine whether the effects vary by country characteristics (Table 10). We initially divide the country sample into two groups: the G7 countries, which are considered to be the source countries of global capital flows, and the non-G7 group, which tend to receive these flows.

We first present results for specifications that use both macroprudential policy shocks and exchange rate shocks, as introduced separately in the sections just above, for the full sample of countries. The results, shown in columns $1-4$, document once again that macroprudential policy shocks have significant effects in reducing credit, and that there is an interaction, where in the presence of a shock to the domestic real exchange rate, a macroprudential tightening reduces the expansionary effect of the appreciation on the credit gap.

The results for different sample splits are shown in columns 5-12. Overall, the effects are strong for the non-G7 group, but not for the G7. In particular, the base effect of the exchange rate on credit developments is significant and strong for the non-G7 group while it is insignificant for $\mathrm{G} 7$ countries (as indicated by the coefficients of $\Delta^{4} R E R_{i, t-1}$ in 
columns 9-12). The same holds for the extent to which tightening macroprudential policy can weaken the interactions between currency and credit movements, being strong and significant for non-G7 but insignificant for G7 countries.

We further divide the non-G7 group into more and less financially open economies ${ }^{15}$ and find that the interaction effects between macroprudential policy and exchange rate shocks remain strong and significant in the more financially open group, despite the reduction in the sample size to 27 countries, while both base and interaction effects are measured statistically insignificant for the group of relative more financially closed economies (columns 13-21). This leads us to conclude that the effects are strongest for small open economies, and less relevant statistically for either advanced economies or relatively closed EMDEs.

\subsection{Alternative Measure of Domestic Credit Developments}

We finally consider an alternative and simpler measure of domestic credit developments. Although the credit gap is a well-established broad-based indicator of systemic risk in the time dimension (Drehmann, 2013), it relies on a statistical filtering of the aggregate credit series that is subject to well-known issues regarding end-date biases, structural breaks, and the parameters driving the filtering. To side-step these criticisms, we employ an alternative and simpler measure, which is the four-quarter change of the credit-to-GDP ratio. As does the credit gap, this measure continues to relate credit aggregates to the size of the economy. It does not however, rely on any filtering method.

When using this alternative outcome variable, our specification continues to employ exchange rate shocks, macroprudential shocks, as well as monetary policy and GDP forecasts as controls. The results, shown in Table 11, document that currency appreciations are associated with increases in credit also using this alternative measure, with results for increases in the ratio of credit to GDP as statistically significant as those for the credit gap. The direct effects of macroprudential policy on the alternative measure of credit appear somewhat weaker, even as the effect remains statistically highly significant for the borrowerbased tools. The strength of the interaction effects, on the other hand, is quite similar to the results using the credit gap, and economically if anything somewhat larger. For example, the coefficient of $M a P P_{i, t-1} \times \Delta^{4} R E R_{i, t-1}$ in column 2 is 0.446 in the bottom panel, compared with 0.256 when using the credit gap (upper panel).

Looking at different groups and specifications of macroprudential policies, the detailed results line up slightly differently. For instance, relaxations of macroprudential policy continue to strengthen the effect of appreciation on credit and this now applies to both

\footnotetext{
${ }^{15}$ We use the de facto financial account openness index developed by Lane and Milesi-Ferretti (2007). We take the average index for each country over the sample period (we take 2015 value for the index in 2016). The more financially open (closed) non-G7 economies are categorized as those having an average index above (below or equal to) the sample median.
} 
borrower-based and financial institution-based tools. Overall, however, the headline results on the link between exchange rates and credit and the interaction effects of macroprudential policy in reducing this link carry over to this alternative measure of credit.

We finally return to the credit gap as the outcome variable and report the results for individual policy tools. Table 12 indicates strong and significant interaction effects for caps on loan-to-value (LTVs) in particular. Those results should be interpreted with caution, however, since when it comes to individual tools, the number of macroprudential actions recorded in the database is in general quite small.

\section{EXTENSION: ThE FEEDBACK EFFECT FROM CREDIT To CAPITAL INFLOWS}

Up until now, we have focused on the role of exchange rate shocks in driving domestic credit developments and the ability of macroprudential policy to attenuate these effects. In this section, we extend our analysis to examine feedback effects from credit developments to specific types of capital inflows and the extent to which these are influenced by domestic policy settings (right-hand side of Figure 1).

More specifically, we examine whether strong domestic credit (as measured by a high lagged credit-to-GDP gap) leads to increases in the so-called "gross other investment inflows" that capture cross-border borrowing by domestic financial institutions and non-financial corporates, and how different types of policies (including monetary policy, macroprudential policy, and capital controls) affect these flows.

As noted already, there is likely to be a two-way causation between capital flows and credit. On the one hand, strong credit demand may cause domestic financial institutions and corporates to "pull in" capital from abroad, as domestic funding sources are exhausted or constrained (Avdjiev, McCauley and McGuire, 2012, Hahm et al., 2013). On the other hand, where capital inflows are strong for other reasons, this may reduce the cost of domestic credit and thereby "push up" domestic credit supply (Mendoza and Terrones, 2012). In general equilibrium, both these effects would lead us to observe a positive correlation between measures of credit and measures of capital inflows.

In our analysis we regress gross other inflows on the lagged credit gap as one way of controlling for reserve causality. In addition, and importantly, we include quarter time-fixed effects to account separately for all global push factors. Inclusion of these quarter fixed effects should render the variation in "other capital flows" that is left to be explained by the credit gap (and other domestic variables) orthogonal to global push factors that might be 
driving an impact running from capital flows to increases in domestic credit. ${ }^{16}$ Despite this, it is difficult to rule out that the coefficient on the credit gap still captures the "push" effect that runs from inflows to credit to some extent. ${ }^{17} \mathrm{We}$ therefore prefer to interpret the coefficient on the credit gap in the analysis below as measuring a conditional correlation that is consistent with a feedback relationship, rather than measuring a causal effect.

This analysis is embedded in otherwise standard "push-and-pull" capital flow regressions with domestic factors that have been identified in the existing literature as driving capital inflows, including monetary policy and growth expectations, as well as the 'catch-all' push factor discussed above. We consider three policy levers, macroprudential and monetary policy, as well as capital controls. The main variables we use are the following:

Capital inflows (CFLOW): As our dependent variable we consider gross other investment inflows ${ }^{18}$ because it is these types of flows that have been found to exhibit the most robust positive association with domestic credit (IMF 2017; Igan and Tan 2017). The capital inflows data are expressed in terms of gross other investment inflows within quarter $t$ as a percent of GDP in the previous quarter t-1. The data source is the Financial Flows Analytics (FFA) database consolidated by the IMF Research Department.

Push factors: As discussed above, we include quarterly time-fixed effects $\left(\mu_{t}\right)$, following Ahnert et al. (2018), in order to account for global "push" factors that affect all countries equally to the fullest possible extent. The benefit of these time fixed effects is that they control for all global factors that are common across countries in each period. This can include changes in global risk aversion, the monetary policy stance in advanced economies, and other variables that may be difficult to observe. Time-fixed effects can help control for all these push factors in a parsimonious way.

Pull factors: In line with the existing literature, we include monetary policy and (forecasted) real GDP growth as domestic pull factors (with variable definitions and data sources as before). These variables are meant to capture to what extent tight monetary policy and a positive GDP growth outlook attract cross-border flows.

\footnotetext{
${ }^{16}$ An alternative way to understand this point is to imagine that we were to run a two-step estimation, where other capital inflows are first regressed on a set of time-fixed effects, in order to purge the outcome variable of the effects of global push factors, and where the residual would be used in a second step regression on domestic pull factors, including the credit gap. Basic econometric theory, known as the "Frisch-Waugh-Lovell Theorem" implies that the coefficients of the second step regression would be the same as those shown in our results. See further Davidson and McKinnon (1993, page 19).

${ }^{17}$ For instance, it is possible, that different countries have different sensitivity to global push factors. Our regression set-up cannot control for that, since our data are at the country level, and therefore do not offer sufficient degrees of freedom to include interactions between time- and country-fixed effects.

${ }^{18}$ Gross inflows are net purchases of domestic assets by foreign agents while net flows subtract net purchases of foreign assets by domestic agents. Other investment inflows capture all other investments flows than direct investment, portfolio equity and debt, financial derivatives, and reserves. It includes currency and deposits, loans, insurance and pensions, trade credit and advances, other accounts payable, and SDR allocations.
} 
Capital controls (FARI): Different from the majority of previous studies that consider broadbased measures of capital controls and apply indicators on in- and outflow restrictions of all types of flows, we use an index of controls that are targeted at the type of "other investment (banking and corporate) inflows" we examine in the analysis. The relevant "Financial Accounts Restrictiveness Index" (FARI) is compiled by the IMF's Monetary and Capital Markets Department, based on source data from the IMF's Annual Report on Exchange Arrangements and Exchange Restrictions (AREAER). Following Klein (2012), we distinguish between long-standing capital controls ("walls"), measured as the level of the index on "other investment inflows" for each country in a given quarter, and temporary adjustments ("gates"), measured as incremental changes (+1 for net tightening and -1 for net loosening actions) in such controls.

Our regressions are based on the two equations given below, where we regress gross other capital flows on the credit gap (Y), lagged by one quarter, and we also include lagged policy variables, with separate regressions for long-standing controls and episodic controls. As explained further just below, our main interest is on the interaction effect between measures of capital controls (i.e., the walls and the gates), and the credit gap: do such controls reduce the extent to which high domestic credit stimulates direct borrowing from abroad?

- The "Walls" Effect of Capital Controls (levels, F ARI) + MaPP

$$
\begin{gathered}
\boldsymbol{C F L O W}_{i, t}=\rho \boldsymbol{C F L O W}_{i, t-1}+\beta_{1} \boldsymbol{Y}_{i, t-1}+\beta_{2} \boldsymbol{F A R I}_{i, t-1}+\beta_{3} \boldsymbol{Y}_{i, t-1} \times \boldsymbol{F A R I}_{i, t-1} \\
+\beta_{4} \mathbf{M a P P}_{i, t-1}+\beta_{5} \boldsymbol{Y}_{i, t-1} \times \boldsymbol{M a P P}_{i, t-1}++\beta_{6} \boldsymbol{M P S}_{i, t-1}+\beta_{7} \boldsymbol{Y}_{i, t-1} \times \boldsymbol{M P S}_{i, t-1} \\
+\theta_{i} \Delta^{4} F_{-} R G D P_{i, t-1}+\theta_{t} \boldsymbol{\mu}_{\boldsymbol{t}}+\theta_{i} \boldsymbol{\alpha}_{\boldsymbol{i}}+v_{i, t}
\end{gathered}
$$

- The "Gates" Effect of Capital Controls (1-quarter change, $\triangle \boldsymbol{F}$ ARI $)+$ MaPP

$$
\begin{gathered}
\boldsymbol{C F L O W}_{i, t}=\rho \boldsymbol{C F L O W}_{i, t-1}+\beta_{1} \boldsymbol{Y}_{i, t-1}+\beta_{2} \Delta \boldsymbol{F A R I}_{i, t-1}+\beta_{3} \boldsymbol{Y}_{i, t-1} \times \Delta F A R I_{i, t-1} \\
+\beta_{4} \boldsymbol{M a P P}_{i, t-1}+\beta_{5} \boldsymbol{Y}_{i, t-1} \times \boldsymbol{M a P P}_{i, t-1}++\beta_{6} \boldsymbol{M P S}_{i, t-1}+\beta_{7} \boldsymbol{Y}_{i, t-1} \times \boldsymbol{M P S}_{i, t-1} \\
+\theta_{i} \Delta^{4} F_{-} R G D P_{i, t-1}+\theta_{t} \boldsymbol{\mu}_{t}+\theta_{i} \boldsymbol{\alpha}_{\boldsymbol{i}}+v_{i, t}
\end{gathered}
$$

Cerdeiro and Komaromi (2019) point out the difficulty of identifying the effects of capital controls. On the one hand, these controls do not vary much over time, reducing the power of standard fixed effects regressions. On the other hand, their level could be correlated with a number of country-specific factors, exposing a random effects regression to potential omitted variables. They argue in favor of an identification through interaction effects, by showing in a simple model that capital controls not only affect the unconditional mean of flows, but importantly the sensitivity of flows to various push and pull factors; a point that is usually not exploited in regressions that neglect interactions and assume an additive linear effect of capital controls on the level of capital flows. 
Following Cerdeiro and Komaromi (2019), we include country-fixed effects, in addition to the time-fixed effects, in order to control as tightly as possible for time-invariant omitted variables at the country level. ${ }^{19}$ In addition, and in order to achieve identification of the effects of policies, including capital controls, we include interaction terms to analyze how policies interact with the credit gap (the domestic pull factor of interest) in affecting the level of other investment flows.

The estimation here does not use the previously applied dynamic panel (GMM) model, in the main since the assumption of autocorrelation within individual panel's error terms $v_{i, t}$ is not satisfied in the estimated equation of the feedback effect. The p-value of AR(1) test ranges from 0.62 to 0.8 , implying strong evidence against the first order serial correlation of residuals in differences, and thus would invalidate the moment conditions used in the dynamic panel estimation (Roodman, 2009). ${ }^{20}$

Estimation results for the "Walls" effects of capital controls are presented in Table 13. Throughout, we include macroprudential and monetary policy variables in addition. Panel (a) reports the findings when we use the macroprudential indicators; panel (b) shows results for macroprudential policy shocks that account for reverse causality (as above in section 5.3); and panel (c) reports the finding of a robustness check applying the random effects approach. There are four noteworthy findings:

First, we find evidence that supports the idea that there is a feedback effect from credit to other investment inflows, which arises when a strong domestic credit cycle leads to greater cross-border borrowing by banks and corporates. As indicated by the coefficients of $Y_{t-1}$, a 10 percentage points of GDP increase in the domestic credit gap (close to a one-standard deviation change) is associated with an increase of cross-border capital inflows in the subsequent quarter, ranging from 0.9 to 1.3 percentage points of GDP.

Second, we find that a tight monetary policy stance also leads to a higher level of crossborder capital inflows in the subsequent quarter. A 1 percentage point increase in the policy rate is found to be associated with an increase of about 1.7 percentage points in the ratio of other investment inflows to GDP. The effects are somewhat larger when the macroprudential

\footnotetext{
${ }^{19}$ The random effect regression is considered in a robustness check (see panel c in Tables 13 and 14). It is based on the de-meaned variables (of capital inflows and monetary policy stance) and shock variables (of macroprudential policy shocks, and the shock of capital inflow control for the "gate" effect only). The average credit-to-GDP ratio over sample period by country is considered as an additional country-specific "pull" factor in the random effects regressions.

20 The trade-off is that we may not fully account for the Nickell bias in the estimation of the effect on the lagged dependent variable. The semi-asymptotic bias (assuming $\mathrm{N} \rightarrow \infty$ ) for our sample $\mathrm{T}=68$ is -0.0262 for an autoregressive coefficient equals to 0.72 in the extension section, compared with the bias of -0.0391 in the baseline given its autoregressive coefficient of 0.98 . Although we are not able to quantitatively assess the degree of smearing effect arises from the endogeneity for the two cases, it is reasonable to assume that the smearing effect in the feedback regression is smaller and may not be a major concern.
} 
policy shocks are included. The coefficients on interactions between monetary policy and credit are not significantly different from zero (coefficients are very close to zero and with relatively large standard errors). This implies that the effect of monetary policy on inflows does not appear to depend on whether the level of the domestic credit gap is high or low.

Third, we find that macroprudential policy tightening is also associated with increases in other investment flows, at the margin, with the result being significant for borrower-based tools and in particular when using macroprudential policy shocks. This is in line with the idea that domestic macroprudential policy tightening is associated with cross-border leakages, that is, tends to further increase borrowing from abroad. An average tightening action of borrower-based tools is found to lead to an increase in cross-border borrowing on the order of 1.3-1.5 percentage points of GDP. This is intuitive as the borrower-based tools restrict borrowing from domestic banks, which can be circumvented by borrowing directly from abroad. On the other hand, financial institution-based tools do not tend to have such strong effects on the provision of domestic credit, and they may therefore not give rise to such strong incentives for circumvention. This might explain why we find them to have an insignificant role in affecting other investment flows.

Fourth, and in contrast, targeted long-standing capital controls ("walls") can have sizeable effects in reducing cross-border funding, in particular by affecting the interactions between credit and these other capital inflows. The coefficients of the direct impact of long-standing controls already is negative and significant (at the 10 percent significance level), and these controls also have a significant indirect effect in mitigating the impact of a high credit gap in increasing cross-border funding (again significant at the 10 and sometimes 5 per cent level). ${ }^{21}$ Hence, this suggests that these long-standing targeted controls are indeed acting as a "wall" when the credit "tide" is up and risks pulling in additional capital from abroad.

As for the episodic controls (Table 14), both the direct effect and indirect effect of capital controls have the expected negative coefficients, although they are not always statistically significant. When we use "shocks" to capital controls, the statistical significance of the base effect improves in some regressions, pointing to the presence of a reverse causality bias that needs to be addressed. ${ }^{22}$ However, the interaction effects between episodic controls and the credit gap remain insignificant throughout. The associated standardized coefficients of episodic controls (added in blue) are also much smaller than those of the long-standing controls. These findings are in line with prior evidence suggesting that the effects of

\footnotetext{
${ }^{21}$ These results broadly hold for the random effect model (panel c), although the direct effects of capital controls are smaller and less significant.

${ }^{22}$ Shocks to capital controls are computed in a manner analogous to the way we construct macroprudential policy shocks, by first running an ordered probit of the gates measure of controls on the same set of variables used to compute macroprudential shocks, including the credit gap, the change in the real exchange rate and the net capital inflow, and then using the difference between the actual value on the indicator and its conditional expectation.
} 
incremental changes in capital controls are weaker, relative to the effect of long-standing controls.

Overall, this evidence suggests that macroprudential policy and capital controls have a complementary role in mitigating systemic risk, with long-standing and targeted capital controls useful when strong domestic credit pulls in additional capital inflows and this cannot be controlled by macroprudential measures and would be exacerbated by monetary tightening. Our comparison of "walls" and "gates" also suggests that when targeted controls are applied to specific types of flows to complement domestic macroprudential measures, these controls may be more effectively deployed in a precautionary manner, ahead of the occurrence of a surge in such flows.

\section{Conclusion \& Policy Implications}

This paper examines the effectiveness of macroprudential policies in attenuating the impact of real exchange rate movements on domestic credit cycles, as well as the roles of macroprudential policies and capital inflow controls in alleviating the feedback effect when a domestic credit boom pulls in cross-border capital inflows, potentially further increasing systemic risk.

Using dynamic panel regression and a novel dataset of macroprudential policy measures that covers a large sample of 62 economies over 2000: Q1-2016: Q4 period, we find robust evidence that exchange rate appreciation is associated with subsequent increases in the credit-to-GDP gap-a well-known early warning indicator of future financial crises. Importantly, we find that tighter macroprudential policies can mitigate this effect.

We also find evidence supporting the effectiveness of targeted capital inflow controls, especially long-standing ones, in dampening a feedback effect that arises when strong domestic credit leads to increases in borrowing from abroad, and macroprudential policies are insufficient or themselves associated with cross-border spillovers.

Therefore, if the feedback effect from credit to direct cross-border borrowing is expected to be strong, policymakers may consider a complementary use of macroprudential policies and capital inflow controls, even as alternatives and tradeoffs should be considered carefully. 


\section{REFERENCES}

Ahnert, T., K. Forbes, C. Friedrich, and D. Reinhardt. 2018. "Macroprudential FX Regulations: Shifting the Snowbanks of FX Vulnerability?” Bank of England Working Paper No. 758.

Akinci, O., and J. Omstead-Rumsey. 2018. "How Effective Are Macroprudential Policies? An Empirical Investigation." Journal of Financial Intermediation 33: 33-57. https://doi.org/10.1016/j.jfi.2017.04.001.

Alam, Z., A. Alter, J. Eiseman, G. Gelos, H. Kang, M. Narita, E. Nier, and N. Wang. 2019. "Digging Deeper-Evidence on the Effects of Macroprudential Policies from a New Database." IMF Working Paper WP/19/66.

Amri, P. D., G. M. Richey, and T. D. Willett. 2016. "Capital Surges and Credit Booms: How Tight is the Relationship?" Open Economies Review, Springer, vol. 27(4), pp. 637-670, September.

Arellano, M. and O. Bover. 1995. "Another Look at the Instrumental Variable Estimation of Error-Components Models.” Journal of Econometrics Vol. 68 (1): pp. 29-51.

Arellano, M., and S. Bond. 1991. "Some Tests of Specification for Panel Data: Monte Carlo Evidence and an Application to Employment Equations." Review of Economic Studies 58: pp. 277-97.

Auerbach, A. J. and Y. Gorodnichenko. 2013. "Output Spillovers from Fiscal Policy." American Economic Review, American Economic Association, vol. 103(3), pages 141-146, May.

Avdjiev, S, R McCauley, and P McGuire. 2012. "Rapid Credit Growth and International Credit: Challenges for Asia.” BIS Working Papers, No 377, April.

Bank for International Settlements. 2019. BIS Annual Economic Report 2019. June 2019.

Basel Committee on Banking Supervision (BCBS). 2010. Guidance for National Authorities Operating the Countercyclical Capital Buffer. Basel Commitee on Banking Supervision. Vol. December.

Baskaya, Y.S., J. Di Giovanni, S. Kalemli-Özcan, J. L. Peydró, and M.F. Ulu. 2017. “Capital Flows and the International Credit Channel.” Journal of International Economics, 108, pp. S15-S22.

Blanchard, O., J. D. Ostry, A. R. Gosh, and M. Chamon. 2015. “Are Capital Inflows Expansionary or Contractionary? Theory, Policy Implications, and Some Evidence.” IMF Working Paper WP/15/226.

Borio, C. 2014. “The Financial Cycle and Macroeconomics: What have we Learnt?" Journal of Banking \& Finance, Elsevier, Vol. 45(C), pp. 182-198. 
Borio, C., R. McCauley and P. McGuire. 2011. "Global Credit and Domestic Credit Booms" Bank for International Settlements BIS Quarterly Review, September 2011, pp. 43-57

Borio, C., and H. Zhu. 2012. "Capital Regulation, Risk-Taking and Monetary Policy: A Missing Link in the Transmission Mechanism?” Journal of Financial Stability 8 (4): 236-51. https://doi.org/10.1016/j.jfs.2011.12.003.

Brandao-Marques, L., R. G. Gelos, M. Narita, and E. 2020. "Leaning Against the Wind: A Cost-Benefit Analysis for an Integrated Policy Framework.” IMF Working Papers 20/123, International Monetary Fund.

Bruno, V., I. Shim, and H. S. Shin. 2017. "Comparative Assessment of Macroprudential Policies." Journal of Financial Stability 28: 183-202. https://doi.org/10.1016/j.jfs.2016.04.001.

Bruno, V., and H. S. Shin. 2015a. "Capital Flows and the Risk-Taking Channel of Monetary Policy.” Journal of Monetary Economics 71: 119-32. https://doi.org/10.1016/j.jmoneco.2014.11.011.

. 2015b. "Cross-Border Banking and Global Liquidity." Review of Economic Studies 82 (2): 535-64. https://doi.org/10.1093/restud/rdu042.

Bun, M. J.G. and T. D. Harrison. 2019. "OLS and IV Estimation of Regression Models Including Endogenous Interaction Terms." Econometric Reviews 38:7, 814-827.

Caballero, J. A. 2016. "Do Surges in International Capital Inflows Influence the Likelihood of Banking Crises?” The Economic Journal, Volume 126, Issue 591, March. pp. 281-316.

Caballero, R., and A. Krisnamurthy. 2004. "Exchange Rate Volatility and the Credit Channel in Emerging Markets: A Vertical Perpective." NBER Working Paper No. 10517

Carstens, A., 2019, "Exchange Rates and Monetary Frameworks in Emerging Market Economies," Lecture at the London School of Economics, London, May 2, 2019.

Cerdeiro, D. A. and A. Komaromi. 2019. "Financial Openness and Capital Inflows to Emerging Markets: In Search of Robust Evidence," IMF Working Papers 19/194, International Monetary Fund.

Cerutti, E., S. Claessens, and L. Laeven. 2017. "The Use and Effectiveness of Macroprudential Policies: New Evidence.” Journal of Financial Stability 28: 203-24. https://doi.org/10.1016/j.jfs.2015.10.004.

Cerutti, E., S. Claessens, A. K. Rose. 2017. "How Important Is the Global Financial Cycle? Evidence from Capital Flows.” Bank for International Settlements Working Paper No. 661

Cerutti, E. and H. Zhou, 2018. "Cross-border Banking and the Circumvention of 
Macroprudential and Capital Control Measures.” IMF Working Papers 18/217, International Monetary Fund.

Cespedes, L. F., R. Chang, and A. Velasco. 2004. "Balance Sheets and Exchange Rate Policy.” American Economic Review 94 (4), pp. 1183-1193.

Claessens, S., S. R. Ghosh, and R. Mihet. 2013. "Macro-Prudential Policies to Mitigate Financial System Vulnerabilities." Journal of International Money and Finance 39: 153-85. https://doi.org/10.1016/j.jimonfin.2013.06.023.

Davidson, R. and J. G. MacKinnon. 1993. "Estimation and Inference in Econometrics." OUP Catalogue, Oxford University Press.

Drehmann, M. 2013. “Total Credit as an Early Warning Indicator for Systemic Banking Crises.” BIS Quarterly Review, Bank for International Settlements. June.

Elekdag, S. and Y. Wu. 2011. "Rapid Credit Growth; Boon or Boom-Bust?” IMF Working Papers 11/241, International Monetary Fund.

Fendoğlu, S.. 2017. "Credit Cycles and Capital Flows: Effectiveness of the Macroprudential Policy Framework in Emerging Market Economies." Journal of Banking and Finance 79: 110-28. https://doi.org/10.1016/j.jbankfin.2017.03.008.

Forbes, K., M. Fratzscher, and R. Straub. 2015. "Capital Flow Management Measures: What Are They Good For?” NBER Working Paper No. 20860, January.

Furceri D., P. Loungani, and A. Zdzienicka, 2016. "The Effects of Monetary Policy Shocks on Inequality.” IMF Working Papers 16/245, International Monetary Fund.

Galati, G. and R. Moessner. 2018. "What Do We Know About the Effects of Macroprudential Policy?” Economica, Vol. 85: pp. 735-70.

Gertler, M., S. Gilchrist and F. M. Natalucci. 2007. "External Constraints on Monetary Policy and the Financial Accelerator." Journal of Money, Credit and Banking, Blackwell Publishing, Vol. 39(2-3), pp. 295-330, March.

Ghosh, A.R., Ostry, J.D. and Qureshi, M.S., 2018. "Taming the Tide of Capital Flows: A Policy Guide." MIT Press Books, 1.

Gourinchas, P. O., and M. Obstfeld. 2012. "Stories of the Twentieth Century for the TwentyFirst." American Economic Journal: Macroeconomics 4 (1): 226-65. https://doi.org/10.1257/mac.4.1.226.

Gruss, B. and K. Suhaib. 2019. "Commodity Terms of Trade: A New Database.” IMF Working Paper WP/19/21.

Hahm, J., H. S. Shin, and K. Shin. 2013. "Non-Core Bank Liabilities and Financial Vulnerability." Journal Of Money, Credit and Banking 45 (1): 1-40. 
https://doi.org/10.1161/JAHA.115.001851.

Hofmann, B., I. Shim, and H. S. Shin. 2019. "Bond Risk Premia and the Exchange Rate." BIS Working Paper No. 775 (775).

Igan, D., and Z. Tan. 2017. "Capital Inflows, Credit Growth, and Financial Systems." Emerging Markets Finance and Trade 53 (12): 2649-71. https://doi.org/10.1080/1540496X.2017.1339186.

IMF-FSB-BIS. 2016. "Elements of Effective Macroprudential Policies," no. August: 1-22. https://doi.org/10.1177/0018726713492349.

IMF. 2017. "Increasing Resilience to Large and Volatile Capital Flows : The Role of Macroprudential." IMF Policy Paper 17/260. Washington, D.C.

Kiviet, J.F., 1995. “On Bias, Inconsistency, and Efficiency of Various Estimators in Dynamic Panel Data Models." Journal of Econometrics, 68(1): 53-78.

Klein, M. W. 2012. “Capital Controls: Gates versus Walls.” NBER Working Paper 18526. Cambridge, MA.

Krippner, L., 2016. "Documentation for Measures of Monetary Policy.” Reserve Bank of New Zealand. Wellington, New Zealand.

Krugman P. 1999. "Balance Sheets, the Transfer Problem, and Financial Crises." In: Isard P., Razin A., Rose A.K. (eds) International Finance and Financial Crises. Springer, Dordrecht. pp. 31-55.

Lane, P and P. McQuade. 2014. "Domestic Credit Growth and International Capital Flows." Scandinavian Journal of Economics, vol 116, issue 1, January, pp 218-52.

Lane, P. and G. M. Milesi-Ferretti. 2007. "The External Wealth of Nations Mark II: Revised and Extended Estimates of Foreign Assets and Liabilities," Journal of International Economics, Vol. 73, No. 2, pp. 223-50.

Lang, J. H., and P. Welz. 2018. "Semi-Structural Credit Gap Estimation.” ECB Working Paper 2194. https://doi.org/10.2866/817670.

Lim, C. H., F. Columba, A. Costa, P. Kongsamut, A. Otani, M. Saiyid, T. Wezel, and X. Wu. 2011. "Macroprudential Policy: What Instruments and How to Use Them? Lessons from Country Experiences." IMF Working Paper Series WP/11/238: 1-85. https://doi.org/10.1080/1350293X.2011.623511.

Mendoza, E. G., and M. E. Terrones. 2012. "An Anatomy of Credit Booms and their Demis." NBER Working Paper 18379. Cambridge, MA 02138.

Merrouche, O., and E. Nier. 2017. "Capital Inflows, Monetary Policy, and Financial Imbalances." Journal of International Money and Finance 77: 117-42. 
https://doi.org/10.1016/j.jimonfin.2017.05.004.

Ostry, J. D., A. R. Ghosh, K. Habermeier, M. Chamon, M. S. Qureshi, L. Laeven, and A. Kokenyne. 2011, "Managing Capital Inflows: What Tools to Use?" IMF Staff Discussion Note 11/06.

Phillips, P. C. B., and H. R. Moon. 2000. "Nonstationary Panel Data Analysis : An Overview of Some Recent Developments" Econometric Review 19 (3): 263-286.

Reinhardt, D. and R. Sowerbutts. 2015. "Regulatory Arbitrage in Action: Evidence from Banking Flows and Macroprudential Policy." Bank of England Working Paper No. 546,

Roodman, D.. 2009. "How to do xtabond2: An introduction to difference and system GMM in Stata." The Stata Journal 9(1): 86-136.

Rossi, B.. 2013. "Exchange Rate Predictability.” Journal of Economic Literature 51 (514): pp. 1063-1119.

Shin, H. S. 2018. "Bank Capital and Monetary Policy Transmission." in Hartmann, P., Huang, H., and Schoenmaker, D. (eds) The Changing Fortunes of Central Banking. Cambridge: Cambridge University Press, pp. 80-100.

Vandenbussche, J., U. Vogel, and E. Detragiache. 2015. "Macroprudential Policies and Housing Prices: A New Database and Empirical Evidence for Central, Eastern, and Southeastern Europe." Journal of Money, Credit and Banking 47 (S1): 343-77.

Windmeijer, F. 2005. "A Finite Sample Correction for the Variance of Linear Efficient Twostep GMM Estimators." Journal of Econometrics 126(1): pp. 25-51. 
Table 1. Description of Variables

\begin{tabular}{|c|c|c|c|}
\hline Variable & Symbol & Description & Sources \\
\hline $\begin{array}{l}\text { Dependent variab } \\
\text { Credit-to-GDP } \\
\text { gap }\end{array}$ & $\frac{e:}{Y}$ & $\begin{array}{l}\text { Calculated by one-sided HP filter using } \\
\text { smoothing parameter }=400,000 \text {. (a) (b) }\end{array}$ & $\begin{array}{l}\text { IMF IFS; BIS; } \\
\text { central banks }\end{array}$ \\
\hline $\begin{array}{l}\text { Independent varia } \\
\text { Macroprudential } \\
\text { policy stance }\end{array}$ & $\begin{array}{l}\text { bles: } \\
\text { MaPP } \\
T \_M a P P \\
L \_M a P P\end{array}$ & $\begin{array}{l}+1 \text { represents a tightening action is taken within } \\
\text { the quarter; }-1 \text { represents a loosening action is } \\
\text { taken within the quarter; } 0 \text { represents no policy } \\
\text { action is taken within the quarter. } i M a P P \text { is the } \\
\text { aggregated measure, } M a P P B B r \text { is the borrower- } \\
\text { based measure, and } M a P P \text { F } \\
\text { institutions-based measure. }\end{array}$ & $\begin{array}{l}\text { IMF iMaPP } \\
\text { Database }\end{array}$ \\
\hline $\begin{array}{l}\text { YoY change of } \\
\text { real exchange } \\
\text { rate }\end{array}$ & $\Delta^{4} R E R$ & $\begin{array}{l}\text { Year-over-year log change of weighted average } \\
\text { (c) of quarterly bilateral nominal exchange rate in } \\
\text { NC per USD, deflated by U.S. CPI against } \\
\text { domestic CPI. Positive value = depreciation } \\
\text { against USD. }\end{array}$ & IMF IFS \\
\hline $\begin{array}{l}\text { Control variables: } \\
\text { Monetary policy } \\
\text { stance }\end{array}$ & $M P S$ & $\begin{array}{l}\text { Central bank policy rates. Use shadow policy } \\
\text { rates for Euro Area, U.S., U.K., and Japan. }\end{array}$ & $\begin{array}{l}\text { IMF IFS, BIS, } \\
\text { and Krippner } \\
\text { (2016) }\end{array}$ \\
\hline $\begin{array}{l}\text { Forecasted YoY } \\
\text { real GDP growth }\end{array}$ & $\Delta^{4} F_{-} R G D P$ & $\begin{array}{l}\text { Year-over-year quarterly log change of } \\
\text { forecasted real GDP growth. It is a weighted } \\
\text { average of current year's and next year's } \\
\text { forecasted growth rates. See details in footnote } \\
10\end{array}$ & $\begin{array}{l}\text { Consensus } \\
\text { Forecast, } \\
\text { IMF WEO }\end{array}$ \\
\hline $\begin{array}{l}\text { Other variables: } \\
\text { YoY real GDP } \\
\text { growth }\end{array}$ & $\Delta^{4} R G D P$ & $\begin{array}{l}\text { Year-over-year log change of quarterly real } \\
\text { GDP. }\end{array}$ & IMF WEO \\
\hline Capital inflows & CFLOW & $\begin{array}{l}\text { Gross other investment inflows within quarter } t \\
\text { (as percent of GDP in } t-1 \text { ). }\end{array}$ & IMF FFA \\
\hline Capital control & $F A R I$ & $\begin{array}{l}\text { Financial account restriction index on gross } \\
\text { other investment inflows, range } 0-1 \text { (higher } \\
\text { values indicate more restrictive system). }\end{array}$ & IMF AREAER \\
\hline
\end{tabular}

Note: (a) Initially take the first 24 quarters, then compute the trend and cyclical components recursively (add one quarter at a time).

(b) We use the financial corporations' domestic claims on private sector from IMF IFS where available, otherwise, we use depository corporations (or monetary) domestic claims on private sector from IMF IFS. The credit data of Iceland and Taiwan POC are from the central banks.

(c) The weighted average of variable $X$ is calculated as $X$ $W A=0.4^{*} X+0.3^{*} L 1 . X+0.2^{*} L 2 . X+0.1^{*} L 4 . X$ 
Table 2. Summary of Statistics

\begin{tabular}{lrrrrrrrr}
\hline Variable & Mean & Median & St. Dev & Min & P25 & P75 & Max & Obs \\
\hline$Y$ & -1.227 & 0.330 & 11.785 & -99.806 & -2.970 & 3.572 & 63.642 & 4,112 \\
$\Delta^{4} R E R$ & -0.502 & -0.675 & 9.198 & -23.474 & -6.246 & 4.844 & 25.934 & 4,152 \\
$M P S$ & 4.172 & 3.301 & 5.159 & -5.728 & 1.000 & 6.000 & 26.000 & 4,083 \\
$\Delta^{4} R G D P$ & 3.256 & 3.199 & 3.676 & -8.781 & 1.319 & 5.504 & 12.296 & 4,212 \\
$\Delta^{4} F \_R G D P$ & 3.169 & 3.071 & 2.292 & -3.517 & 1.776 & 4.613 & 9.225 & 4,216 \\
CFLOW & 5.514 & 1.502 & 25.824 & -60.800 & -1.702 & 6.632 & 169.592 & 4,120 \\
$F A R I$ & 0.181 & 0.167 & 0.166 & 0 & 0.083 & 0.250 & 0.750 & 3,904 \\
$\Delta F A R I$ & -0.001 & 0.000 & 0.025 & -0.333 & -0.250 & 0.250 & 0.500 & 3,903 \\
iMaPP & 0.095 & 0.000 & 0.626 & -4 & 0 & 0 & 6 & 4,216 \\
$M a P P \_B r$ & 0.020 & 0.000 & 0.229 & -2 & 0 & 0 & 3 & 4,216 \\
$M a P P \_F I$ & 0.070 & 0.000 & 0.543 & -4 & 0 & 0 & 5 & 4,216 \\
\hline
\end{tabular}

Source: Authors' calculations.

Note: We winsorize the top and bottom 1 percent observations of each variable except the dependent variable $\mathrm{Y}$ and the ordinal variable MaPP. 


\section{Table 3. Definition of Macroprudential Policy Instruments}

\begin{tabular}{|c|c|c|}
\hline & Instrument & Definition \\
\hline 1 & CCB & $\begin{array}{l}\text { A requirement for banks to maintain a countercyclical capital buffer. } \\
\text { Implementations at } 0 \% \text { are not considered as a tightening in dummy-type } \\
\text { indicators. }\end{array}$ \\
\hline 2 & LVR & $\begin{array}{l}\text { A limit on leverage of banks, calculated by dividing a measure of capital by the } \\
\text { bank's non-risk-weighted exposures. }\end{array}$ \\
\hline 3 & ШP & $\begin{array}{l}\text { Loan loss provision requirements, which include dynamic provisioning and } \\
\text { sectoral provisions (e.g. for impaired or housing loans). }\end{array}$ \\
\hline 4 & Capital & $\begin{array}{l}\text { Capital requirements for banks, which include risk weights, systemic risk buffers, } \\
\text { and minimum capital requirements. Countercyclical capital buffers and capital } \\
\text { conservation buffers are captured in their sheets respectively and thus not } \\
\text { included here. }\end{array}$ \\
\hline 5 & LTV & $\begin{array}{l}\text { Limits to the loan-to-value ratios, mostly targeted at housing loans, but also } \\
\text { includes those targeted at automobile loans. }\end{array}$ \\
\hline 6 & DSTI & $\begin{array}{l}\text { Limits to the debt-service-to-income ratio and the loan-to-income ratio, which } \\
\text { restrict the size of debt services or debt relative to income. }\end{array}$ \\
\hline 7 & LFC & $\begin{array}{l}\text { Limits on foreign currency (FC) lending, and rules or recommendations on FC } \\
\text { loans. }\end{array}$ \\
\hline 8 & $\mathrm{RR}$ & $\begin{array}{l}\text { Reserve requirements (on domestic or foreign currency) for macroprudential } \\
\text { purposes. }\end{array}$ \\
\hline 9 & Tax & $\begin{array}{l}\text { Taxes and levies applied to specified transactions, assets, or liabilities, which } \\
\text { include stamp duties, capital gain taxes, and levies on banks' noncore funding. }\end{array}$ \\
\hline 10 & SIF & $\begin{array}{l}\text { Identification of and additional buffer requirements for global and domestic } \\
\text { systemically important financial institutions. }\end{array}$ \\
\hline 11 & Liquidity & $\begin{array}{l}\text { Regulations for liquidity and funding risks, including minimum requirements for } \\
\text { liquidity coverage ratios, liquid asset ratios, net stable funding ratios, and core } \\
\text { funding ratios. }\end{array}$ \\
\hline 12 & LTD & Limits to the loan-to-deposit (LTD) ratio and penalties for high LTD ratios. \\
\hline 13 & LFX & $\begin{array}{l}\text { Limits on net or gross open foreign exchange (FX) positions, limits on FX } \\
\text { exposures and FX funding, and currency mismatch regulations. }\end{array}$ \\
\hline 14 & LCG & $\begin{array}{l}\text { Limits on growth or the volume of aggregate credit, the household-sector } \\
\text { credit, or the corporate-sector credit by banks, and penalties for high credit } \\
\text { growth. }\end{array}$ \\
\hline 15 & Conservation & Requirements for banks' capital conservation buffers. \\
\hline 16 & LoanR & $\begin{array}{l}\text { Loan restrictions, that are more tailored than those captured in "14.LCG". They } \\
\text { include loan limits and prohibitions, which may be targeted at loan } \\
\text { characteristics (e.g., the maturity, the size, the LTV ratio and the type of interest } \\
\text { rate of loans), bank characteristics (e.g., mortgage banks), and other factors. } \\
\text { Restrictions on foreign currency lending are captured in "7.LFC". External debt } \\
\text { restrictions for banks are captured in "13. LFX". }\end{array}$ \\
\hline 17 & Other & $\begin{array}{l}\text { Explicitly macroprudential regulation not included elsewhere, such as stress } \\
\text { testing, restrictions on profit distribution and limits on foreign investment. }\end{array}$ \\
\hline
\end{tabular}

Source: Alam et al. (2019). We exclude SIFI from the original database to construct the aggregated macroprudential policy measure because this paper focuses on the time dimension of systemic risk. 
Table 4. Baseline Results

\begin{tabular}{|c|c|c|c|c|c|c|c|c|c|c|c|c|}
\hline \multirow[b]{2}{*}{ Variables } & \multicolumn{4}{|c|}{ iMaPP } & \multicolumn{4}{|c|}{ Borrower-based tools } & \multicolumn{4}{|c|}{ Financial institutions-based tools } \\
\hline & (1) & (2) & (3) & (4) & (5) & (6) & (7) & (8) & (9) & (10) & (11) & (12) \\
\hline$Y_{t-1}$ & $\begin{array}{c}0.982^{\star \star *} \\
(0.020)\end{array}$ & $\begin{array}{c}0.989^{\star \star *} \\
(0.018)\end{array}$ & $\begin{array}{c}0.986^{\star \star *} \\
(0.020)\end{array}$ & $\begin{array}{c}0.991^{\star * *} \\
(0.018)\end{array}$ & $\begin{array}{c}0.988^{\star \star *} \\
(0.020)\end{array}$ & $\begin{array}{c}0.988^{\star \star *} \\
(0.019)\end{array}$ & $\begin{array}{c}0.987^{\star \star *} \\
(0.019)\end{array}$ & $\begin{array}{c}0.988^{\star * *} \\
(0.017)\end{array}$ & $\begin{array}{c}0.983^{\star \star \star} \\
(0.021)\end{array}$ & $\begin{array}{c}0.989^{\star \star \star} \\
(0.019)\end{array}$ & $\begin{array}{c}0.987^{\star * \star} \\
(0.021)\end{array}$ & $\begin{array}{c}0.991^{\star * *} \\
(0.020)\end{array}$ \\
\hline$\Delta^{4} R E R_{t-1}$ & $\begin{array}{c}-0.050^{\star *} \\
(0.021)\end{array}$ & $\begin{array}{c}-0.054^{\star \star \star} \\
(0.018)\end{array}$ & $\begin{array}{c}-0.053^{\star \star} \\
(0.022)\end{array}$ & $\begin{array}{c}-0.052^{\star * *} \\
(0.019)\end{array}$ & $\begin{array}{c}-0.053^{\star *} \\
(0.021)\end{array}$ & $\begin{array}{c}-0.060^{\star \star *} \\
(0.018)\end{array}$ & $\begin{array}{c}-0.054^{\star \star} \\
(0.021)\end{array}$ & $\begin{array}{c}-0.056^{\star \star *} \\
(0.019)\end{array}$ & $\begin{array}{c}-0.051^{\star *} \\
(0.021)\end{array}$ & $\begin{array}{c}-0.053^{\star \star \star} \\
(0.020)\end{array}$ & $\begin{array}{c}-0.054^{\star \star} \\
(0.021)\end{array}$ & $\begin{array}{c}-0.050^{\star \star \star} \\
(0.019)\end{array}$ \\
\hline$a P P_{t-1}$ & $\begin{array}{l}-0.875^{*} \\
(0.463)\end{array}$ & $\begin{array}{l}-0.737 \\
(0.461)\end{array}$ & & & $\begin{array}{c}-2.231^{\star *} \\
(1.016)\end{array}$ & $\begin{array}{l}-1.990^{*} \\
(1.087)\end{array}$ & & & $\begin{array}{l}-0.416 \\
(0.502)\end{array}$ & $\begin{array}{l}-0.365 \\
(0.397)\end{array}$ & & \\
\hline${ }_{t} P_{t-1} \times \Delta^{4} R E R_{t-1}$ & & $\begin{array}{c}\mathbf{0 . 1 4 4} \\
(0.048)\end{array}$ & & & & $\begin{array}{l}\mathbf{0 . 2 5 3 ^ { * }} \\
(0.151)\end{array}$ & & & & $\begin{array}{c}\mathbf{0 . 1 4 8}^{* * *} \\
(0.049)\end{array}$ & & \\
\hline$T_{-} M a P P_{t-1}$ & & & $\begin{array}{c}-1.168^{* *} \\
(0.524)\end{array}$ & $\begin{array}{l}-0.852^{\star} \\
(0.503)\end{array}$ & & & $\begin{array}{l}-2.000 \\
(1.395)\end{array}$ & $\begin{array}{l}-1.620 \\
(1.597)\end{array}$ & & & $\begin{array}{l}-1.149 \\
(0.728)\end{array}$ & $\begin{array}{l}-0.810 \\
(0.624)\end{array}$ \\
\hline$M a P P_{t-1} \times \Delta^{4} R E R_{t-1}$ & & & & $\begin{array}{c}\mathbf{0 . 1 3 0 * *} \\
(0.061)\end{array}$ & & & & $\begin{array}{c}\mathbf{0 . 2 7 0}^{* *} \\
(0.135)\end{array}$ & & & & $\begin{array}{l}\mathbf{0 . 1 1 2}^{*} \\
(0.067)\end{array}$ \\
\hline$L_{-} M a P P_{t-1}$ & & & $\begin{array}{l}0.027 \\
(0.754)\end{array}$ & $\begin{array}{l}-0.630 \\
(0.709)\end{array}$ & & & $\begin{array}{c}-3.034^{\star *} \\
(1.535)\end{array}$ & $\begin{array}{l}-2.886 \\
(1.878)\end{array}$ & & & $\begin{array}{c}0.504 \\
(1.184)\end{array}$ & $\begin{array}{l}-0.028 \\
(0.934)\end{array}$ \\
\hline$L_{-} M a P P_{t-1} \times \Delta^{4} R E R_{t-1}$ & & & & $\begin{array}{c}\mathbf{0 . 1 5 9 * * *} \\
(0.042)\end{array}$ & & & & $\begin{array}{c}0.224 \\
(0.201)\end{array}$ & & & & $\begin{array}{c}\mathbf{0 . 1 6 0 * * *} \\
(0.052)\end{array}$ \\
\hline$M P S_{t-1}$ & $\begin{array}{c}-0.269^{\star \star \star} \\
(0.074)\end{array}$ & $\begin{array}{c}-0.246^{\star \star \star} \\
(0.069)\end{array}$ & $\begin{array}{c}-0.264^{\star \star \star} \\
(0.073)\end{array}$ & $\begin{array}{c}-0.245^{\star \star \star} \\
(0.073)\end{array}$ & $\begin{array}{c}-0.290^{* \star *} \\
(0.073)\end{array}$ & $\begin{array}{c}-0.273^{\star * *} \\
(0.072)\end{array}$ & $\begin{array}{c}-0.285^{\star \star \star} \\
(0.073)\end{array}$ & $\begin{array}{c}-0.290^{\star \star *} \\
(0.074)\end{array}$ & $\begin{array}{c}-0.262^{\star \star \star} \\
(0.069)\end{array}$ & $\begin{array}{c}-0.240^{\star \star \star} \\
(0.072)\end{array}$ & $\begin{array}{c}-0.263^{\star \star \star} \\
(0.071)\end{array}$ & $\begin{array}{c}-0.249^{\star \star \star} \\
(0.072)\end{array}$ \\
\hline$\Delta^{4} F_{-} R G D P_{t-1}$ & $\begin{array}{c}0.504^{\star \star \star} \\
(0.077)\end{array}$ & $\begin{array}{c}0.462^{\star \star \star} \\
(0.085)\end{array}$ & $\begin{array}{c}0.503^{\star \star *} \\
(0.080)\end{array}$ & $\begin{array}{c}0.453^{\star * \star} \\
(0.089)\end{array}$ & $\begin{array}{c}0.496^{\star \star *} \\
(0.074)\end{array}$ & $\begin{array}{c}0.453^{\star * \star} \\
(0.079)\end{array}$ & $\begin{array}{c}0.492^{* \star *} \\
(0.073)\end{array}$ & $\begin{array}{c}0.473^{\star * *} \\
(0.076)\end{array}$ & $\begin{array}{c}0.465^{\star \star \star} \\
(0.077)\end{array}$ & $\begin{array}{c}0.447^{\star \star \star} \\
(0.078)\end{array}$ & $\begin{array}{c}0.473^{* * *} \\
(0.082)\end{array}$ & $\begin{array}{c}0.457^{\star \star \star} \\
(0.083)\end{array}$ \\
\hline Observations & 3,842 & 3,842 & 3,842 & 3,842 & 3,842 & 3,842 & 3,842 & 3,842 & 3,842 & 3,842 & 3,842 & 3,842 \\
\hline \# of Economies & 62 & 62 & 62 & 62 & 62 & 62 & 62 & 62 & 62 & 62 & 62 & 62 \\
\hline$A B A R(1)$ test $-p$ value & 0.00183 & 0.000741 & 0.00157 & 0.000754 & 0.00180 & 0.000833 & 0.00160 & 0.000735 & 0.00279 & 0.00133 & 0.00184 & 0.00121 \\
\hline$A B A R(2)$ test - $p$ value & 0.394 & 0.257 & 0.264 & 0.250 & 0.350 & 0.255 & 0.373 & 0.278 & 0.390 & 0.297 & 0.281 & 0.253 \\
\hline Hansen test - $p$ value & 1 & 1 & 1 & 1 & 1 & 1 & 1 & 1 & 1 & 1 & 1 & 1 \\
\hline
\end{tabular}

Note: Standard errors in parentheses. ${ }^{* *} p<0.01,{ }^{* *} p<0.05,{ }^{*} p<0$. 
Table 5. Robustness-Results with Actual GDP Growth Rates

\begin{tabular}{|c|c|c|c|c|c|c|c|c|c|c|c|c|}
\hline \multirow[b]{2}{*}{ Variables } & \multicolumn{4}{|c|}{ iMaPP } & \multicolumn{4}{|c|}{ Borrower-based tools } & \multicolumn{4}{|c|}{ Financial institutions-based tools } \\
\hline & (1) & (2) & (3) & (4) & (5) & (6) & (7) & (8) & (9) & (10) & (11) & (12) \\
\hline$Y_{t-1}$ & $\begin{array}{c}0.983^{\star \star \star} \\
(0.017)\end{array}$ & $\begin{array}{c}0.990^{\star \star \star} \\
(0.016)\end{array}$ & $\begin{array}{c}0.984^{\star \star \star} \\
(0.018)\end{array}$ & $\begin{array}{c}0.988^{\star \star \star} \\
(0.017)\end{array}$ & $\begin{array}{c}0.987^{\star \star \star} \\
(0.017)\end{array}$ & $\begin{array}{c}0.987^{\star \star \star} \\
(0.016)\end{array}$ & $\begin{array}{c}0.988^{\star \star *} \\
(0.017)\end{array}$ & $\begin{array}{c}0.987^{\star \star \star} \\
(0.016)\end{array}$ & $\begin{array}{c}0.986^{\star \star *} \\
(0.019)\end{array}$ & $\begin{array}{c}0.990^{\star \star \star} \\
(0.017)\end{array}$ & $\begin{array}{c}0.984^{\star \star \star} \\
(0.017)\end{array}$ & $\begin{array}{r}0.990^{\star \star \star} \\
(0.017)\end{array}$ \\
\hline$\Delta^{4} R E R_{t-1}$ & $\begin{array}{c}-0.056^{\star \star \star} \\
(0.021)\end{array}$ & $\begin{array}{c}-0.056^{\star * *} \\
(0.018)\end{array}$ & $\begin{array}{c}-0.052^{\star *} \\
(0.022)\end{array}$ & $\begin{array}{c}-0.049^{\star * *} \\
(0.019)\end{array}$ & $\begin{array}{c}-0.058^{\star \star *} \\
(0.020)\end{array}$ & $\begin{array}{c}-0.061^{\star * *} \\
(0.017)\end{array}$ & $\begin{array}{c}-0.057^{\star \star *} \\
(0.020)\end{array}$ & $\begin{array}{c}-0.058^{\star \star *} \\
(0.018)\end{array}$ & $\begin{array}{c}-0.058^{\star \star *} \\
(0.020)\end{array}$ & $\begin{array}{c}-0.057^{\star \star \star} \\
(0.019)\end{array}$ & $\begin{array}{c}-0.057^{\star \star \star} \\
(0.020)\end{array}$ & $\begin{array}{r}-0.047^{\text {** }} \\
(0.022)\end{array}$ \\
\hline$M a P P_{t-1}$ & $\begin{array}{c}-0.894^{\star *} \\
(0.404)\end{array}$ & $\begin{array}{c}-0.745^{\star \star} \\
(0.350)\end{array}$ & & & $\begin{array}{c}-2.269^{\star *} \\
(0.965)\end{array}$ & $\begin{array}{c}-1.955^{\star \star} \\
(0.996)\end{array}$ & & & $\begin{array}{l}-0.483 \\
(0.515)\end{array}$ & $\begin{array}{l}-0.392 \\
(0.477)\end{array}$ & & \\
\hline $\operatorname{MaPP}_{t-1} \times \Delta^{4} R E R_{t-1}$ & & $\begin{array}{c}0.158^{\star \star \star} \\
(0.050)\end{array}$ & & & & $\begin{array}{l}0.264^{\star} \\
(0.145)\end{array}$ & & & & $\begin{array}{c}0.171^{\star \star \star} \\
(0.049)\end{array}$ & & \\
\hline$T_{-} M a P P_{t-1}$ & & & $\begin{array}{c}-1.030^{\star *} \\
(0.437)\end{array}$ & $\begin{array}{l}-0.752 \\
(0.487)\end{array}$ & & & $\begin{array}{l}-2.097 \\
(1.381)\end{array}$ & $\begin{array}{l}-1.640 \\
(1.381)\end{array}$ & & & $\begin{array}{l}-0.890 \\
(0.707)\end{array}$ & $\begin{array}{l}-0.721 \\
(0.872)\end{array}$ \\
\hline$T_{-} M a P P_{t-1} \times \Delta^{4} R E R_{t-1}$ & & & & $\begin{array}{l}0.128^{\star} \\
(0.067)\end{array}$ & & & & $\begin{array}{l}0.303^{* *} \\
(0.154)\end{array}$ & & & & $\begin{array}{c}0.094 \\
(0.081)\end{array}$ \\
\hline$L_{-} M a P P_{t-1}$ & & & $\begin{array}{l}-0.331 \\
(0.747)\end{array}$ & $\begin{array}{l}-1.155 \\
(0.739)\end{array}$ & & & $\begin{array}{c}-3.156^{\star \star} \\
(1.582)\end{array}$ & $\begin{array}{l}-2.664 \\
(1.834)\end{array}$ & & & $\begin{array}{c}0.231 \\
(1.155)\end{array}$ & $\begin{array}{l}-0.468 \\
(0.690)\end{array}$ \\
\hline$L_{-} M a P P_{t-1} \times \Delta^{4} R E R_{t-1}$ & & & & $\begin{array}{c}0.191^{\star \star \star} \\
(0.060)\end{array}$ & & & & $\begin{array}{c}0.093 \\
(0.264)\end{array}$ & & & & $\begin{array}{c}0.201^{\star \star \star} \\
(0.046)\end{array}$ \\
\hline$M P S_{t-1}$ & $\begin{array}{c}-0.220^{\star * \star} \\
(0.067)\end{array}$ & $\begin{array}{c}-0.186^{\star \star \star} \\
(0.061)\end{array}$ & $\begin{array}{c}-0.206^{* * *} \\
(0.069)\end{array}$ & $\begin{array}{c}-0.180^{* *} \\
(0.080)\end{array}$ & $\begin{array}{c}-0.241^{* * *} \\
(0.062)\end{array}$ & $\begin{array}{c}-0.209^{\star * \star} \\
(0.063)\end{array}$ & $\begin{array}{c}-0.248^{\star * *} \\
(0.064)\end{array}$ & $\begin{array}{c}-0.235^{\star * \star} \\
(0.064)\end{array}$ & $\begin{array}{c}-0.208^{* * \star} \\
(0.066)\end{array}$ & $\begin{array}{c}-0.183^{* * *} \\
(0.063)\end{array}$ & $\begin{array}{c}-0.197^{\star * \star} \\
(0.063)\end{array}$ & $\begin{array}{c}-0.197^{\text {** }} \\
(0.077)\end{array}$ \\
\hline$\Delta^{4} R G D P_{t-1}$ & $\begin{array}{c}0.290 \star \star \star \\
(0.052)\end{array}$ & $\begin{array}{c}0.264^{\star * *} \\
(0.047)\end{array}$ & $\begin{array}{c}0.277^{\star \star *} \\
(0.049)\end{array}$ & $\begin{array}{c}0.269 * * * \\
(0.050)\end{array}$ & $\begin{array}{c}0.262^{\star \star \star} \\
(0.053)\end{array}$ & $\begin{array}{c}0.239 * \star * \\
(0.049)\end{array}$ & $\begin{array}{c}0.256^{\star \star \star} \\
(0.050)\end{array}$ & $\begin{array}{c}0.252^{\star \star \star} \\
(0.045)\end{array}$ & $\begin{array}{c}0.267^{\star \star \star} \\
(0.057)\end{array}$ & $\begin{array}{c}0.255^{\star \star \star} \\
(0.055)\end{array}$ & $\begin{array}{c}0.252^{\star \star \star} \\
(0.048)\end{array}$ & $\begin{array}{r}0.257^{\star \star \star} \\
(0.053)\end{array}$ \\
\hline Observations & 3,842 & 3,842 & 3,842 & 3,842 & 3,842 & 3,842 & 3,842 & 3,842 & 3,842 & 3,842 & 3,842 & 3,842 \\
\hline \# of Economies & 62 & 62 & 62 & 62 & 62 & 62 & 62 & 62 & 62 & 62 & 62 & 62 \\
\hline$A B A R(1)$ test - $p$ value & 0.002 & 0.001 & 0.002 & 0.001 & 0.002 & 0.001 & 0.002 & 0.001 & 0.003 & 0.001 & 0.003 & 0.002 \\
\hline$A B A R(2)$ test - $p$ value & 0.356 & 0.226 & 0.290 & 0.311 & 0.328 & 0.242 & 0.347 & 0.280 & 0.365 & 0.252 & 0.298 & 0.285 \\
\hline Hansen test - $p$ value & 1 & 1 & 1 & 1 & 1 & 1 & 1 & 1 & 1 & 1 & 1 & 1 \\
\hline
\end{tabular}

Source: Authors' calculations.

Note: Standard errors in parentheses. ${ }^{* * *} p<0.01,{ }^{* *} p<0.05,{ }^{*} p<0.1$ 
Table 6. "Purging" the Real Exchange Rate

\begin{tabular}{|c|c|c|}
\hline & (1) & (2) \\
\hline & FE & FE \\
\hline \multirow[t]{2}{*}{$\Delta^{4}$ Inflation $_{t}$} & $0.252^{\star \star \star}$ & $0.260^{\star \star \star \star}$ \\
\hline & $(0.061)$ & (0.069) \\
\hline \multirow[t]{2}{*}{$\Delta^{4} F_{-} R G D P_{t}$} & $-2.111^{\star \star \star *}$ & $-2.215^{\star \star \star}$ \\
\hline & $(0.166)$ & (0.182) \\
\hline \multirow[t]{2}{*}{$\Delta^{4} C A \_D e f i c i t_{t}$} & & -0.000 \\
\hline & & $(0.000)$ \\
\hline \multirow[t]{2}{*}{ Constant } & $5.259^{\star \star \star}$ & $5.211^{\star \star *}$ \\
\hline & $(0.612)$ & $(0.650)$ \\
\hline Observations & 4,151 & 3,804 \\
\hline R-squared & 0.041 & 0.040 \\
\hline \# of Economies & 62 & 60 \\
\hline
\end{tabular}

Source: Authors' calculations.

Note: (a) Standard errors in parentheses. ${ }^{* * *} p<0.01,{ }^{* *} p<0.05,{ }^{*} p<0.1$

(b) FE Regression (1): $\Delta^{4} \boldsymbol{R} \boldsymbol{E} \boldsymbol{R}_{i, t}=\beta_{1} \Delta^{4}$ Inflation $_{i, t}+\beta_{2} \Delta^{4} \boldsymbol{F}_{-} \boldsymbol{R} \boldsymbol{G D} \boldsymbol{P}_{i, t}+\eta_{i}+e_{i, t}$

(c) FE Regression (2): $\Delta^{4} \boldsymbol{R} E \boldsymbol{R}_{i, t}=\beta_{1} \Delta^{4}$ Inflation $_{i, t}+\beta_{2} \Delta^{4} \boldsymbol{F}_{-} \boldsymbol{R} \boldsymbol{G} \boldsymbol{D} \boldsymbol{P}_{i, t}+\beta_{3} \Delta^{4} \boldsymbol{C A}_{-}$Deficit $_{i, t}+\eta_{i}+e_{i, t}$ 
Table 7. Robustness-Results with "Purged” Exchange Rate Shocks

\begin{tabular}{|c|c|c|c|c|c|c|c|c|c|c|c|c|}
\hline \multirow[b]{3}{*}{ Variables } & \multirow{2}{*}{\multicolumn{4}{|c|}{ Baseline }} & \multicolumn{4}{|c|}{$\begin{array}{c}\Delta^{4} R E R=\text { Residuals from FE } \\
\text { Regression (1) }\end{array}$} & \multicolumn{4}{|c|}{$\begin{array}{c}\Delta^{4} R E R=\text { Residuals from FE } \\
\text { Regression (2) }\end{array}$} \\
\hline & & & & & & $\mathrm{iMc}$ & & & & & & \\
\hline & (1) & (2) & (3) & $(4)$ & (5) & $(6)$ & $(7)$ & (8) & $(9)$ & $(10)$ & (11) & (12) \\
\hline$\Delta^{4} R E R_{t-1}$ & $\begin{array}{l}-0.050^{\star \star} \\
(0.021)\end{array}$ & $\begin{array}{c}-0.054^{\star \star *} \\
(0.018)\end{array}$ & $\begin{array}{l}-0.053^{\star \star} \\
(0.022)\end{array}$ & $\begin{array}{c}-0.052^{\star \star \star} \\
(0.019)\end{array}$ & $\begin{array}{l}-0.044^{\star \star} \\
(0.022)\end{array}$ & $\begin{array}{c}-0.054^{\star \star *} \\
(0.021)\end{array}$ & $\begin{array}{l}-0.044^{\star *} \\
(0.022)\end{array}$ & $\begin{array}{l}-0.046^{\star *} \\
(0.020)\end{array}$ & $\begin{array}{l}-0.033^{*} \\
(0.020)\end{array}$ & $\begin{array}{l}-0.043^{\star *} \\
(0.019)\end{array}$ & $\begin{array}{l}-0.033^{*} \\
(0.019)\end{array}$ & $\begin{array}{l}-0.039^{* *} \\
(0.018)\end{array}$ \\
\hline $\operatorname{MaPP}_{t-1}$ & $\begin{array}{l}-0.875^{\star} \\
(0.463)\end{array}$ & $\begin{array}{l}-0.737 \\
(0.461)\end{array}$ & & & $\begin{array}{l}-0.866^{\star *} \\
(0.414)\end{array}$ & $\begin{array}{c}-1.351^{\star * *} \\
(0.512)\end{array}$ & & & $\begin{array}{l}-0.940 * \\
(0.481)\end{array}$ & $\begin{array}{c}-1.461^{\star \star \star} \\
(0.424)\end{array}$ & & \\
\hline $\operatorname{MaPP}_{t-1} \times \Delta^{4} R E R_{t-1}$ & & $\begin{array}{c}0.144^{\star \star *} \\
(0.048)\end{array}$ & & & & $\begin{array}{l}0.206^{* *} \\
(0.085)\end{array}$ & & & & $\begin{array}{l}0.188^{\star \star} \\
(0.078)\end{array}$ & & \\
\hline$T_{-} M a P P_{t-1}$ & & & $\begin{array}{l}-1.168^{\star \star} \\
(0.524)\end{array}$ & $\begin{array}{l}-0.852^{*} \\
(0.503)\end{array}$ & & & $\begin{array}{l}-1.161^{\star *} \\
(0.471)\end{array}$ & $\begin{array}{c}-1.566^{\star \star \star} \\
(0.592)\end{array}$ & & & $\begin{array}{c}-1.476^{\star \star \star} \\
(0.515)\end{array}$ & $\begin{array}{c}-2.034^{\star * \star} \\
(0.618)\end{array}$ \\
\hline$T_{-} M a P P_{t-1} \times \Delta^{4} R E R_{t-1}$ & & & & $\begin{array}{l}0.130^{\star *} \\
(0.061)\end{array}$ & & & & $\begin{array}{l}0.168^{\star \star} \\
(0.067)\end{array}$ & & & & $\begin{array}{l}0.157^{\star *} \\
(0.071)\end{array}$ \\
\hline$L_{-} M a P P_{t-1}$ & & & $\begin{array}{l}0.027 \\
(0.754)\end{array}$ & $\begin{array}{l}-0.630 \\
(0.709)\end{array}$ & & & $\begin{array}{l}0.009 \\
(0.832)\end{array}$ & $\begin{array}{l}-0.711 \\
(0.927)\end{array}$ & & & $\begin{array}{c}0.293 \\
(0.898)\end{array}$ & $\begin{array}{l}-0.570 \\
(0.786)\end{array}$ \\
\hline$L_{-} M a P P_{t-1} \times \Delta^{4} R E R_{t-1}$ & & & & $\begin{array}{c}0.159^{\star \star \star} \\
(0.042)\end{array}$ & & & & $\begin{array}{c}0.257 \\
(0.159)\end{array}$ & & & & $\begin{array}{l}0.281^{\star} \\
(0.149)\end{array}$ \\
\hline Observations & 3,842 & 3,842 & 3,842 & 3,842 & 3,841 & 3,841 & 3,841 & 3,841 & 3,544 & 3,544 & 3,544 & 3,544 \\
\hline \# of Economies & 62 & 62 & 62 & 62 & 62 & 62 & 62 & 62 & 60 & 60 & 60 & 60 \\
\hline
\end{tabular}

Source: Authors' calculations.

Note: (a) Standard errors in parentheses. ${ }^{* *} p<0.01,{ }^{* *} p<0.05,{ }^{*} p<0.1$

(b) FE Regression (1): $\Delta^{\mathbf{4}} \boldsymbol{R} \boldsymbol{E} \boldsymbol{R}_{\boldsymbol{i}, \boldsymbol{t}}=\beta_{1} \Delta^{\mathbf{4}}$ Inflation $_{\boldsymbol{i}, \boldsymbol{t}}+\beta_{2} \Delta^{\mathbf{4}} \boldsymbol{F}_{-} \boldsymbol{R} \boldsymbol{G D P} \boldsymbol{P}_{\boldsymbol{i}, \boldsymbol{t}}+\eta_{i}+e_{i, t}$

(c) FE Regression (2): $\Delta^{4} \boldsymbol{R} \boldsymbol{E} \boldsymbol{R}_{i, \boldsymbol{t}}=\beta_{1} \Delta^{4}$ Inflation $_{i, \boldsymbol{t}}+\beta_{2} \Delta^{\mathbf{4}} \boldsymbol{F}_{-} \boldsymbol{R} \boldsymbol{G D P} \boldsymbol{P}_{\boldsymbol{i}, \boldsymbol{t}}+\beta_{3} \Delta^{4} \boldsymbol{C A}_{-}$Deficit $_{i, \boldsymbol{t}}+\eta_{i}+e_{i, t}$ 
Table 8. Results from Ordered Probit Regression

\begin{tabular}{|c|c|c|c|}
\hline VARIABLES & $\begin{array}{c}\text { iMaPP } \\
(1) \\
\end{array}$ & $\begin{array}{c}\text { MaPP_Br } \\
\text { (2) }\end{array}$ & $\begin{array}{c}\text { MaPP_FI } \\
(3) \\
\end{array}$ \\
\hline$\Delta^{4} Y_{t-1}$ & $\begin{array}{l}0.009^{\star \star} \\
(0.004)\end{array}$ & $\begin{array}{c}0.006 \\
(0.006)\end{array}$ & $\begin{array}{c}0.011^{\star \star \star} \\
(0.004)\end{array}$ \\
\hline$\Delta^{4} \boldsymbol{R} E \boldsymbol{R}_{t-1}$ & $\begin{array}{c}0.001 \\
(0.001)\end{array}$ & $\begin{array}{c}0.001 \\
(0.002)\end{array}$ & $\begin{array}{c}0.001 \\
(0.001)\end{array}$ \\
\hline$\Delta^{4} N C F L O W_{t-1}$ & $\begin{array}{c}0.000 \\
(0.000)\end{array}$ & $\begin{array}{c}0.000 \\
(0.001)\end{array}$ & $\begin{array}{l}0.000 \\
(0.000)\end{array}$ \\
\hline$\sum_{s=-4}^{-1} M_{a P P_{s}}$ & $\begin{array}{c}0.110^{\star \star \star} \\
(0.014)\end{array}$ & $\begin{array}{c}0.029 \\
(0.021)\end{array}$ & $\begin{array}{c}0.117^{\star \star *} \\
(0.014)\end{array}$ \\
\hline Constant cut 1 & $\begin{array}{c}-2.076^{\star \star \star} \\
(0.169)\end{array}$ & $\begin{array}{c}-2.882^{\star \star \star} \\
(0.335)\end{array}$ & $\begin{array}{c}-2.165^{\star \star \star} \\
(0.175)\end{array}$ \\
\hline Constant cut2 & $\begin{array}{c}-1.383^{\star \star \star} \\
(0.163)\end{array}$ & $\begin{array}{c}-2.167^{\star \star \star} \\
(0.308)\end{array}$ & $\begin{array}{c}-1.483^{\star \star *} \\
(0.168)\end{array}$ \\
\hline Constant cut3 & $\begin{array}{c}1.490^{\star \star \star} \\
(0.163)\end{array}$ & $\begin{array}{c}2.168^{\star \star \star} \\
(0.308)\end{array}$ & $\begin{array}{c}1.585^{\star \star \star} \\
(0.168)\end{array}$ \\
\hline Constant cut 4 & $\begin{array}{c}2.193^{\star \star \star} \\
(0.166)\end{array}$ & $\begin{array}{c}2.950 \star \star \star \\
(0.319)\end{array}$ & $\begin{array}{c}2.345^{\star \star \star} \\
(0.173)\end{array}$ \\
\hline Observations & 3,699 & 3,699 & 3,699 \\
\hline
\end{tabular}

Source: Authors' calculations.

Note: (1) Robust standard errors in parentheses. ${ }^{* *} p<0.01$, ** $p<0.05$, * $p<0.1$

(2) The constant cut points represent the thresholds of predicted cumulative normal distribution of the dependent variable corresponding to its different categorical values. 
Table 9. Robustness-Results with Macroprudential Policy Shocks

\begin{tabular}{|c|c|c|c|c|c|c|c|c|c|c|c|c|}
\hline \multirow[b]{2}{*}{ Variables } & \multicolumn{4}{|c|}{ iMaPP } & \multicolumn{4}{|c|}{ Borrower-based tools } & \multicolumn{4}{|c|}{ Financial institutions-based tools } \\
\hline & (1) & (2) & (3) & (4) & (5) & (6) & (7) & (8) & (9) & $(10)$ & $(11)$ & (12) \\
\hline$Y_{t-1}$ & $\begin{array}{c}0.988^{\star \star *} \\
(0.019)\end{array}$ & $\begin{array}{c}0.993^{* \star *} \\
(0.017)\end{array}$ & $\begin{array}{c}0.989^{\star \star \star} \\
(0.019)\end{array}$ & $\begin{array}{c}0.991 \text { *** } \\
(0.017)\end{array}$ & $\begin{array}{c}0.993^{* * *} \\
(0.018)\end{array}$ & $\begin{array}{c}0.990^{\star \star *} \\
(0.017)\end{array}$ & $\begin{array}{c}0.992^{\star \star *} \\
(0.019)\end{array}$ & $\begin{array}{c}0.991^{\star \star \star} \\
(0.018)\end{array}$ & $\begin{array}{c}0.989 * * * \\
(0.019)\end{array}$ & $\begin{array}{c}0.993^{\star \star *} \\
(0.018)\end{array}$ & $\begin{array}{c}0.988^{\star \star *} \\
(0.019)\end{array}$ & $\begin{array}{c}0.989^{\star \star *} \\
(0.015)\end{array}$ \\
\hline$\Delta^{4} R E R_{t-1}$ & $\begin{array}{c}-0.058^{\star \star \star} \\
(0.020)\end{array}$ & $\begin{array}{c}-0.055^{\star \star \star} \\
(0.019)\end{array}$ & $\begin{array}{l}-0.057^{\star \star \star} \\
(0.021)\end{array}$ & 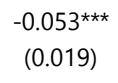 & $\begin{array}{l}-0.054^{\star *} \\
(0.022)\end{array}$ & $\begin{array}{c}-0.058^{\star \star \star} \\
(0.021)\end{array}$ & $\begin{array}{l}-0.056^{\star \star} \\
(0.023)\end{array}$ & $\begin{array}{l}-0.058^{\star \star \star} \\
(0.022)\end{array}$ & $\begin{array}{l}-0.057^{\star *} \\
(0.023)\end{array}$ & $\begin{array}{c}-0.054^{\star \star *} \\
(0.020)\end{array}$ & $\begin{array}{c}-0.060^{\star \star \star} \\
(0.020)\end{array}$ & $\begin{array}{c}-0.053^{\star \star \star} \\
(0.019)\end{array}$ \\
\hline$x P P_{\_} S_{h o c k} k_{t-1}$ & $\begin{array}{c}-1.088^{\star *} \\
(0.490)\end{array}$ & $\begin{array}{c}-1.240^{\star *} \\
(0.529)\end{array}$ & & & $\begin{array}{c}-1.988^{\star *} \\
(0.884)\end{array}$ & $\begin{array}{l}-1.891^{*} \\
(0.986)\end{array}$ & & & $\begin{array}{c}-1.157^{* *} \\
(0.562)\end{array}$ & $\begin{array}{c}-1.343^{\star *} \\
(0.576)\end{array}$ & & \\
\hline$P_{P} S_{-} h_{o c k} k_{t-1} \times \Delta^{4} R E R_{t-1}$ & & $\begin{array}{c}\mathbf{0 . 1 7 8}^{* * *} \\
(0.048)\end{array}$ & & & & $\begin{array}{l}\mathbf{0 . 2 4 0 *} \\
(0.136)\end{array}$ & & & & $\begin{array}{c}\mathbf{0 . 1 9 2}^{* * *} \\
(0.050)\end{array}$ & & \\
\hline$T_{-} M a P P \_S h o c k_{t-1}$ & & & $\begin{array}{c}-2.090^{\star * *} \\
(0.702)\end{array}$ & $\begin{array}{c}-1.979^{\star \star} \\
(0.797)\end{array}$ & & & $\begin{array}{l}-1.970 \\
(1.247)\end{array}$ & $\begin{array}{l}-1.658 \\
(1.389)\end{array}$ & & & $\begin{array}{c}-2.870^{\star \star *} \\
(0.931)\end{array}$ & $\begin{array}{c}-2.522^{\star *} \\
(1.069)\end{array}$ \\
\hline MaPP_Shock t-1 $_{-} \times \Delta^{4} R E R_{t-1}$ & & & & $\begin{array}{c}\mathbf{0 . 2 1 5 * * *} \\
(0.077)\end{array}$ & & & & $\begin{array}{l}\mathbf{0 . 3 1 7}^{*} \\
(0.181)\end{array}$ & & & & $\begin{array}{c}\mathbf{0 . 2 5 1 ^ { * * }} \\
(0.107)\end{array}$ \\
\hline$L_{-} M a P P \_S h o c k k_{t-1}$ & & & $\begin{array}{c}0.914 \\
(0.814)\end{array}$ & $\begin{array}{c}0.392 \\
(0.795)\end{array}$ & & & $\begin{array}{l}-2.371 \\
(1.455)\end{array}$ & $\begin{array}{l}-1.865 \\
(1.650)\end{array}$ & & & $\begin{array}{c}1.784 \\
(1.359)\end{array}$ & $\begin{array}{c}1.161 \\
(1.207)\end{array}$ \\
\hline$L_{-} M a P P \_S h o c k_{t-1} \times \Delta^{4} R E R_{t-1}$ & & & & $\begin{array}{c}\mathbf{0 . 1 2 6 * * *} \\
(0.044)\end{array}$ & & & & $\begin{array}{c}0.012 \\
(0.203)\end{array}$ & & & & $\begin{array}{r}\mathbf{0 . 1 1 6 * *} \\
(0.047)\end{array}$ \\
\hline$M P S_{t-1}$ & $\begin{array}{c}-0.315^{\star \star \star} \\
(0.080)\end{array}$ & $\begin{array}{c}-0.276^{\star \star \star} \\
(0.074)\end{array}$ & $\begin{array}{c}-0.269^{\star \star \star} \\
(0.081)\end{array}$ & $\begin{array}{c}-0.250^{\star \star \star} \\
(0.075)\end{array}$ & $\begin{array}{c}-0.312^{\star \star \star} \\
(0.068)\end{array}$ & $\begin{array}{c}-0.301^{\star \star \star} \\
(0.073)\end{array}$ & $\begin{array}{c}-0.315^{\star \star \star} \\
(0.078)\end{array}$ & $\begin{array}{c}-0.289^{\star \star \star} \\
(0.079)\end{array}$ & $\begin{array}{c}-0.287^{\star \star \star} \\
(0.079)\end{array}$ & $\begin{array}{c}-0.263^{\star \star *} \\
(0.076)\end{array}$ & $\begin{array}{c}-0.249^{\star \star \star} \\
(0.082)\end{array}$ & $\begin{array}{c}-0.221^{\star \star \star} \\
(0.075)\end{array}$ \\
\hline$\Delta^{4} F_{-} R G D P_{t-1}$ & $\begin{array}{c}0.469^{\star \star \star} \\
(0.084)\end{array}$ & $\begin{array}{c}0.452^{\star \star \star} \\
(0.088)\end{array}$ & $\begin{array}{c}0.450^{\star \star \star} \\
(0.091)\end{array}$ & $\begin{array}{c}0.426^{\star \star \star} \\
(0.089)\end{array}$ & $\begin{array}{c}0.443^{* * \star} \\
(0.072)\end{array}$ & $\begin{array}{c}0.459^{\star \star \star} \\
(0.077)\end{array}$ & $\begin{array}{c}0.450^{\star \star \star} \\
(0.076)\end{array}$ & $\begin{array}{c}0.470^{\star \star \star} \\
(0.079)\end{array}$ & $\begin{array}{c}0.485^{\star \star *} \\
(0.077)\end{array}$ & $\begin{array}{c}0.466^{\star \star \star} \\
(0.084)\end{array}$ & $\begin{array}{c}0.461^{\star \star \star} \\
(0.088)\end{array}$ & $\begin{array}{c}0.432^{\star \star *} \\
(0.088)\end{array}$ \\
\hline Observations & 3,505 & 3,505 & 3,505 & 3,505 & 3,505 & 3,505 & 3,505 & 3,505 & 3,505 & 3,505 & 3,505 & 3,505 \\
\hline \# of Economies & 62 & 62 & 62 & 62 & 62 & 62 & 62 & 62 & 62 & 62 & 62 & 62 \\
\hline$A B A R(1)$ test - $p$ value & 0.00341 & 0.000832 & 0.00135 & 0.000387 & 0.00422 & 0.00210 & 0.00411 & 0.00184 & 0.00348 & 0.000896 & 0.000471 & 0.000253 \\
\hline$A B A R(2)$ test - $p$ value & 0.640 & 0.439 & 0.311 & 0.203 & 0.583 & 0.434 & 0.592 & 0.506 & 0.625 & 0.424 & 0.271 & 0.162 \\
\hline Hansen test $-p$ value & 1 & 1 & 1 & 1 & 1 & 1 & 1 & 1 & 1 & 1 & 1 & 1 \\
\hline
\end{tabular}

Source: Authors' calculations.

Note: Robust standard errors in parentheses. ${ }^{* * \star} p<0.01,{ }^{* \star} p<0.05,{ }^{*} p<0.1$ 
Table 10. Effectiveness of Macroprudential Policies by Country Characteristics

\begin{tabular}{|c|c|c|c|c|c|c|c|c|c|c|c|c|c|c|c|c|c|c|c|c|}
\hline & \multicolumn{4}{|c|}{$\begin{array}{l}\text { All (baseline) } \\
\text { iMaPP }\end{array}$} & \multicolumn{4}{|c|}{$\begin{array}{c}\text { G7 } \\
\text { iMaPP }\end{array}$} & \multicolumn{4}{|c|}{$\begin{array}{l}\text { non-G7 } \\
\text { iMaPP }\end{array}$} & \multicolumn{4}{|c|}{$\begin{array}{l}\text { non-G7: Financially open } \\
\text { iMaPP }\end{array}$} & \multicolumn{4}{|c|}{$\begin{array}{l}\text { non-G7: Financially closed } \\
\text { iMaPP }\end{array}$} \\
\hline & (1) & (2) & (3) & (4) & (5) & (6) & (7) & (8) & (9) & (10) & (11) & (12) & (13) & (14) & (15) & (16) & (18) & (19) & (20) & (21) \\
\hline$\Delta^{4} R E R_{-} S_{h} \operatorname{cock}_{t-1}$ & $\begin{array}{l}-0.053^{* \star} \\
(0.021)\end{array}$ & $\begin{array}{l}-0.052^{* *} \\
(0.021)\end{array}$ & $\begin{array}{l}-0.049^{\star \star} \\
(0.020)\end{array}$ & $\begin{array}{l}-0.046^{\star \star} \\
(0.020)\end{array}$ & $\begin{array}{c}0.115 \\
(0.139)\end{array}$ & $\begin{array}{c}4.449 \\
(3.148)\end{array}$ & $\begin{array}{c}0.870 \\
(0.595)\end{array}$ & $\begin{array}{l}-1.114 \\
(1.205)\end{array}$ & $\begin{array}{l}-0.059^{\star \star} \\
(0.024)\end{array}$ & $\begin{array}{l}-0.056^{* *} \\
(0.023)\end{array}$ & $\begin{array}{l}-0.058^{* *} \\
(0.024)\end{array}$ & $\begin{array}{l}-0.060^{\star \star \star} \\
(0.020)\end{array}$ & $\begin{array}{l}-0.066^{* \star} \\
(0.032)\end{array}$ & $\begin{array}{l}-0.056^{* \star} \\
(0.025)\end{array}$ & $\begin{array}{l}-0.067^{* *} \\
(0.030)\end{array}$ & $\begin{array}{l}-0.049 \\
(0.033)\end{array}$ & $\begin{array}{l}-0.048 \\
(0.032)\end{array}$ & $\begin{array}{l}-0.040 \\
(0.032)\end{array}$ & $\begin{array}{l}-0.051 \\
(0.034)\end{array}$ & $\begin{array}{l}-0.094^{\star \star \star} \\
(0.017)\end{array}$ \\
\hline$a P P \_S h o c k_{t-1}$ & $\begin{array}{l}-1.114^{\star \star}- \\
(0.492)\end{array}$ & $\begin{array}{c}-1.794^{\star \star \star} \\
(0.600)\end{array}$ & & & $\begin{array}{c}0.570 \\
(1.171)\end{array}$ & $\begin{array}{l}-80.857 \\
(55.555)\end{array}$ & & & $\begin{array}{l}-0.741 \\
(0.533)\end{array}$ & $\begin{array}{c}-1.391^{\star *} \\
(0.620)\end{array}$ & & & $\begin{array}{c}0.201 \\
(0.607)\end{array}$ & $\begin{array}{l}-0.464 \\
(0.573)\end{array}$ & & & $\begin{array}{c}0.064 \\
(0.336)\end{array}$ & $\begin{array}{c}0.097 \\
(0.285)\end{array}$ & & \\
\hline tPP_Shock ${ }_{t-1} \times \Delta^{4} R^{2} E R_{-}$Shock $_{t-1}$ & & $\begin{array}{c}\mathbf{0 . 2 5 6 * * *} \\
(0.087)\end{array}$ & & & & $\begin{array}{l}15.358 \\
(9.654)\end{array}$ & & & & $\begin{array}{c}\mathbf{0 . 2 4 3}^{* * *} \\
(0.091)\end{array}$ & & & & $\begin{array}{c}\mathbf{0 . 3 1 4}^{* * *} \\
(0.100)\end{array}$ & & & & $\begin{array}{l}-0.014 \\
(0.053)\end{array}$ & & \\
\hline$T_{-}$MaPP_Shock $t_{t-1}$ & & & $\begin{array}{c}-2.460^{\star * \star} \\
(0.717)\end{array}$ & $\begin{array}{l}-2.944^{\star \star \star} \\
(0.758)\end{array}$ & & & $\begin{array}{l}-7.225 \\
(7.761)\end{array}$ & $\begin{array}{l}125.037 \\
(94.092)\end{array}$ & & & $\begin{array}{c}-2.095^{\star \star *} . \\
(0.689)\end{array}$ & $\begin{array}{c}\star-2.747^{\star \star \star} \\
(0.856)\end{array}$ & & & $\begin{array}{l}-1.416 \\
(1.028)\end{array}$ & $\begin{array}{l}-1.798 \\
(1.358)\end{array}$ & & & $\begin{array}{l}-0.309 \\
(0.496)\end{array}$ & $\begin{array}{l}-0.839 \\
(0.969)\end{array}$ \\
\hline MaPP_Shock $_{t-1} \times \Delta^{4} R E R_{-}$Shock $t_{t-}$ & & & & $\begin{array}{l}\mathbf{0 . 2 2 8 * *} \\
(0.096)\end{array}$ & & & & $\begin{array}{l}-31.393 \\
(27.581)\end{array}$ & & & & $\begin{array}{l}\mathbf{0 . 2 3 1 * *} \\
(0.091)\end{array}$ & & & & $\begin{array}{c}\mathbf{0 . 3 0 1} \\
(0.214)\end{array}$ & & & & $\begin{array}{c}0.113 \\
(0.102)\end{array}$ \\
\hline$L_{-} M a P P \_S h o c k_{t-1}$ & & & $\begin{array}{c}0.616 \\
(0.811)\end{array}$ & $\begin{array}{l}-0.433 \\
(1.118)\end{array}$ & & & $\begin{array}{l}22.217 \\
(22.322)\end{array}$ & $\begin{array}{c}0.000 \\
(0.000)\end{array}$ & & & $\begin{array}{c}0.761 \\
(0.788)\end{array}$ & $\begin{array}{l}-0.022 \\
(0.980)\end{array}$ & & & $\begin{array}{l}1.741^{*} \\
(0.894)\end{array}$ & $\begin{array}{c}0.887 \\
(0.994)\end{array}$ & & & $\begin{array}{c}0.676 \\
(0.720)\end{array}$ & $\begin{array}{c}1.444 \\
(0.933)\end{array}$ \\
\hline$L_{-} M a P P \_S h o c k_{t-1} \times \Delta^{4} R E R \_S h o c k$ & & & & $\begin{array}{r}0.260 \\
(0.159)\end{array}$ & & & & $\begin{array}{l}2.604 \\
(4.145)\end{array}$ & & & & $\begin{array}{c}0.231 \\
(0.166)\end{array}$ & & & & $\begin{array}{c}\mathbf{0 . 3 4 6 * * *} \\
(0.071)\end{array}$ & & & & $\begin{array}{l}-0.230 \\
(0.200)\end{array}$ \\
\hline$M P S_{t-1}$ & $\begin{array}{l}-0.303^{\star \star \star}- \\
(0.079)\end{array}$ & $\begin{array}{c}-0.265^{\star \star \star}- \\
(0.077)\end{array}$ & $\begin{array}{c}{ }^{*}-0.295^{\star \star \star} \\
(0.083)\end{array}$ & $\begin{array}{l}-0.266^{\star \star \star} \\
(0.072)\end{array}$ & $\begin{array}{l}-0.011 \\
(0.789)\end{array}$ & $\begin{array}{l}-13.593 \\
(8.843)\end{array}$ & $\begin{array}{l}-6.165 \\
(5.668)\end{array}$ & $\begin{array}{l}-14.144 \\
(10.006)\end{array}$ & $\begin{array}{c}-0.268^{\star \star \star} \\
(0.076)\end{array}$ & $\begin{array}{c}{ }^{*}-0.242^{\star \star \star} \\
(0.072)\end{array}$ & $\begin{array}{l}-0.256^{\star \star \star} \\
(0.075)\end{array}$ & $\begin{array}{c}-0.240^{\star \star \star} \\
(0.068)\end{array}$ & $\begin{array}{l}-0.184^{\star \star} \\
(0.093)\end{array}$ & $\begin{array}{l}-0.231^{*} \\
(0.124)\end{array}$ & $\begin{array}{l}-0.222^{\star *} \\
(0.097)\end{array}$ & $\begin{array}{l}-0.197^{\star} \\
(0.103)\end{array}$ & $\begin{array}{c}-0.255^{\star \star} \\
(0.108)\end{array}$ & $\begin{array}{l}-0.231^{*} \\
(0.124)\end{array}$ & $\begin{array}{l}-0.254^{\star \star} \\
(0.121)\end{array}$ & $\begin{array}{r}-0.202 \\
(0.148)\end{array}$ \\
\hline$\Delta^{4} F_{-} R G D P_{t-1}$ & $\begin{array}{c}0.595^{\star * *} \\
(0.097)\end{array}$ & $\begin{array}{l}0.570^{\star \star \star} \\
(0.103)\end{array}$ & $\begin{array}{l}0.595^{\star \star \star} \\
(0.095)\end{array}$ & $\begin{array}{l}0.564^{\star \star \star} \\
(0.094)\end{array}$ & $\begin{array}{c}0.319 \\
(3.161)\end{array}$ & $\begin{array}{c}6.393 \\
(6.350)\end{array}$ & $\begin{array}{c}2.986 \\
(2.701)\end{array}$ & $\begin{array}{l}-2.944 \\
(3.691)\end{array}$ & $\begin{array}{c}0.568^{\star \star \star} \\
(0.099)\end{array}$ & $\begin{array}{c}0.544^{\star \star \star} \\
(0.099)\end{array}$ & $\begin{array}{l}0.569^{\star \star \star} \\
(0.101)\end{array}$ & $\begin{array}{l}0.545^{\star \star \star} \\
(0.092)\end{array}$ & $\begin{array}{l}0.696^{\star \star \star} \\
(0.152)\end{array}$ & $\begin{array}{c}0.539^{\star \star \star} \\
(0.154)\end{array}$ & $\begin{array}{l}0.658^{\star \star \star} \\
(0.157)\end{array}$ & $\begin{array}{l}0.595^{\star \star \star} \\
(0.183)\end{array}$ & $\begin{array}{c}0.321^{\star \star \star} \\
(0.104)\end{array}$ & $\begin{array}{c}0.296^{\star \star \star} \\
(0.101)\end{array}$ & $\begin{array}{l}0.292^{\star \star \star} \\
(0.113)\end{array}$ & $\begin{array}{c}0.265^{\star * \star} \\
(0.093)\end{array}$ \\
\hline Observations & 3,505 & 3,505 & 3,505 & 3,505 & 406 & 406 & 406 & 406 & 3,099 & 3,099 & 3,099 & 3,099 & 1,558 & 1,558 & 1,558 & 1,558 & 1,541 & 1,541 & 1,541 & 1,541 \\
\hline \# of Economies & 62 & 62 & 62 & 62 & 7 & 7 & 7 & 7 & 55 & 55 & 55 & 55 & 27 & 27 & 27 & 27 & 28 & 28 & 28 & 28 \\
\hline$A B A R(1)$ test - $p$ value & $0.00324 \mathrm{C}$ & 0.000464 & 40.00121 & 0.000261 & 0.0955 & 0.400 & 0.180 & 0.342 & 0.0102 & 0.00196 & 0.00497 & 0.00109 & 0.0489 & 0.0222 & 0.0427 & 0.0217 & 0.0003296 & 30.000300 & 00.000281 & 10.00430 \\
\hline$A B A R(2)$ test $-p$ value & 0.652 & 0.575 & 0.305 & 0.312 & 0.877 & 0.529 & 0.265 & 0.442 & 0.661 & 0.491 & 0.404 & 0.309 & 0.491 & 0.422 & 0.397 & 0.419 & 0.702 & 0.677 & 0.813 & 0.693 \\
\hline Hansen test $-p$ value & 1 & 1 & 1 & 1 & 1 & 1 & 1 & 1 & 1 & 1 & 1 & 1 & 1 & 1 & 1 & 1 & 1 & 1 & 1 & 1 \\
\hline
\end{tabular}




\section{Table 11. Robustness-Alternative and Simpler Measure of Credit Developments}

\begin{tabular}{|c|c|c|c|c|c|c|c|c|c|c|c|c|}
\hline \multirow[b]{2}{*}{ Variables } & \multicolumn{4}{|c|}{ iMaPP } & \multicolumn{4}{|c|}{ Borrower-based tools } & \multicolumn{4}{|c|}{ Financial institutions-based tools } \\
\hline & (1) & (2) & (3) & (4) & (5) & (6) & (7) & (8) & (9) & (10) & (11) & (12) \\
\hline \multicolumn{13}{|l|}{$\underline{\mathbf{Y}=\text { Credit-to-GDP Gap (baseline) }}$} \\
\hline$\Delta^{4} R E R \_S h o c k_{t-1}$ & $\begin{array}{l}-0.053^{\star *} \\
(0.021)\end{array}$ & $\begin{array}{l}-0.052^{* *} \\
(0.021)\end{array}$ & $\begin{array}{l}-0.049^{* *} \\
(0.020)\end{array}$ & $\begin{array}{l}-0.046^{* *} \\
(0.020)\end{array}$ & $\begin{array}{l}-0.049^{* *} \\
(0.025)\end{array}$ & $\begin{array}{l}-0.054^{\star \star} \\
(0.024)\end{array}$ & $\begin{array}{l}-0.049^{* *} \\
(0.022)\end{array}$ & $\begin{array}{l}-0.035^{\star} \\
(0.018)\end{array}$ & $\begin{array}{l}-0.054^{\star *} \\
(0.022)\end{array}$ & $\begin{array}{l}-0.046^{* *} \\
(0.021)\end{array}$ & $\begin{array}{l}-0.051^{\star *} \\
(0.020)\end{array}$ & $\begin{array}{c}-0.055^{* * *} \\
(0.021)\end{array}$ \\
\hline MaPP_Shock ${ }_{t-1}$ & $\begin{array}{l}-1.114^{* *} \\
(0.492)\end{array}$ & $\begin{array}{l}-1.794^{\star \star *} \\
(0.600)\end{array}$ & & & $\begin{array}{l}-2.110^{\star *} \\
(1.021)\end{array}$ & $\begin{array}{l}-4.030^{\star \star} \\
(1.608)\end{array}$ & & & $\begin{array}{l}-1.131^{\star *} \\
(0.552)\end{array}$ & $\begin{array}{c}-1.528^{\star \star \star} \\
(0.524)\end{array}$ & & \\
\hline MaPP_Shock ${ }_{t-1} \times \Delta^{4} R E R \_S h o c k_{t-1}$ & & $\begin{array}{c}\mathbf{0 . 2 5 6 * * *} \\
(0.087)\end{array}$ & & & & $\begin{array}{l}\mathbf{0 . 5 0 6 * *} \\
(0.210)\end{array}$ & & & & $\begin{array}{l}\mathbf{0 . 1 8 5 * *} \\
(0.080)\end{array}$ & & \\
\hline$T_{-} M a P P \_S h o c k_{t-1}$ & & & $\begin{array}{l}-2.460^{\star \star \star} \\
(0.717)\end{array}$ & $\begin{array}{l}-2.944^{\star \star *} \\
(0.758)\end{array}$ & & & $\begin{array}{l}-1.932 \\
(1.646)\end{array}$ & $\begin{array}{l}-2.744^{\star} \\
(1.661)\end{array}$ & & & $\begin{array}{l}-3.358^{\star * \star} \\
(1.046)\end{array}$ & $\begin{array}{c}-3.557^{\star \star *} \\
(1.157)\end{array}$ \\
\hline${ }^{\Gamma} \_M a P P \_S h o c k_{t-1} \times \Delta^{4} R E R \_S h o c k_{t-1}$ & & & & $\begin{array}{l}\mathbf{0 . 2 2 8}^{* *} \\
(0.096)\end{array}$ & & & & $\begin{array}{l}\mathbf{0 . 2 4 5 * *} \\
(0.098)\end{array}$ & & & & $\begin{array}{l}\mathbf{0 . 2 1 4} \\
(0.104)\end{array}$ \\
\hline$L_{-} M a P P \_S h o c k_{t-1}$ & & & $\begin{array}{c}0.616 \\
(0.811)\end{array}$ & $\begin{array}{r}-0.433 \\
(1.118)\end{array}$ & & & $\begin{array}{l}-2.677^{*} \\
(1.516)\end{array}$ & $\begin{array}{l}-6.619^{*} \\
(3.438)\end{array}$ & & & $\begin{array}{c}1.451 \\
(1.216)\end{array}$ & $\begin{array}{c}1.087 \\
(1.172)\end{array}$ \\
\hline$L_{-} M a P P \_S h o c k_{t-1} \times \Delta^{4} R E R \_S h o c k_{t-1}$ & & & & $\begin{array}{r}\mathbf{0 . 2 6 0} \\
(0.159)\end{array}$ & & & & $\begin{array}{l}1.052^{\star \star *} \\
(0.353)\end{array}$ & & & & $\begin{array}{c}\mathbf{0 . 1 3 2} \\
(0.081)\end{array}$ \\
\hline $\begin{array}{l}\text { Observations } \\
\text { \# of Economies }\end{array}$ & $\begin{array}{c}3,505 \\
62\end{array}$ & $\begin{array}{c}3,505 \\
62\end{array}$ & $\begin{array}{c}3,505 \\
62\end{array}$ & $\begin{array}{c}3,505 \\
62\end{array}$ & $\begin{array}{c}3,505 \\
62\end{array}$ & $\begin{array}{c}3,505 \\
62\end{array}$ & $\begin{array}{c}3,505 \\
62\end{array}$ & $\begin{array}{c}3,505 \\
62\end{array}$ & $\begin{array}{c}3,505 \\
62\end{array}$ & $\begin{array}{c}3,505 \\
62\end{array}$ & $\begin{array}{c}3,505 \\
62\end{array}$ & $\begin{array}{c}3,505 \\
62\end{array}$ \\
\hline$\underline{Y}=4$-quarter change of credit/GDP ratio & & & & & & & & & & & & \\
\hline$\Delta^{4} R E R \_S h o c k_{t-1}$ & $\begin{array}{l}-0.105^{\star *} \\
(0.047)\end{array}$ & $\begin{array}{l}-0.114^{\star \star} \\
(0.050)\end{array}$ & $\begin{array}{l}-0.100^{* *} \\
(0.044)\end{array}$ & $\begin{array}{l}-0.012 \\
(0.056)\end{array}$ & $\begin{array}{l}-0.108^{* *} \\
(0.047)\end{array}$ & $\begin{array}{l}-0.114^{\star \star} \\
(0.053)\end{array}$ & $\begin{array}{l}-0.108^{\star *} \\
(0.050)\end{array}$ & $\begin{array}{l}-0.058 \\
(0.037)\end{array}$ & $\begin{array}{l}-0.103^{* *} \\
(0.050)\end{array}$ & $\begin{array}{l}-0.107^{* *} \\
(0.045)\end{array}$ & $\begin{array}{l}-0.099^{* *} \\
(0.047)\end{array}$ & $\begin{array}{l}-0.046 \\
(0.051)\end{array}$ \\
\hline MaPP_Shock ${ }_{t-1}$ & $\begin{array}{c}0.151 \\
(0.912)\end{array}$ & $\begin{array}{l}-0.926 \\
(0.913)\end{array}$ & & & $\begin{array}{l}-2.524^{*} \\
(1.509)\end{array}$ & $\begin{array}{c}-3.866^{\star \star \star} \\
(1.392)\end{array}$ & & & $\begin{array}{c}0.697 \\
(0.843)\end{array}$ & $\begin{array}{l}-0.257 \\
(0.825)\end{array}$ & & \\
\hline MaPP_Shock ${ }_{t-1} \times \Delta^{4} R E R \_S h o c k_{t-1}$ & & $\begin{array}{c}\mathbf{0 . 4 4 6 * *} \\
(0.222)\end{array}$ & & & & $\begin{array}{c}0.457 \\
(0.379)\end{array}$ & & & & $\begin{array}{l}\text { 0.345* } \\
(0.204)\end{array}$ & & \\
\hline$T_{-}$MaPP_Shock $k_{t-1}$ & & & $\begin{array}{l}-1.656 \\
(1.398)\end{array}$ & $\begin{array}{l}-0.954 \\
(1.205)\end{array}$ & & & $\begin{array}{l}-3.644^{\star \star} \\
(1.526)\end{array}$ & $\begin{array}{l}-1.964 \\
(2.191)\end{array}$ & & & $\begin{array}{l}-1.078 \\
(1.816)\end{array}$ & $\begin{array}{l}-0.794 \\
(1.404)\end{array}$ \\
\hline${ }^{\prime} \_$MaPP_Shock ${ }_{t-1} \times \Delta^{4} R E R \_S h o c k_{t-1}$ & & & & $\begin{array}{l}-0.034 \\
(0.223)\end{array}$ & & & & $\begin{array}{l}-0.267 \\
(0.215)\end{array}$ & & & & $\begin{array}{c}\mathbf{0 . 0 4 4} \\
(0.165)\end{array}$ \\
\hline$L_{-} M a P P \_S h o c k_{t-1}$ & & & $\begin{array}{c}2.746 \\
(2.202)\end{array}$ & $\begin{array}{l}-0.394 \\
(1.792)\end{array}$ & & & $\begin{array}{c}1.242 \\
(3.425)\end{array}$ & $\begin{array}{l}-5.159 \\
(4.213)\end{array}$ & & & $\begin{array}{c}3.310 \\
(2.806)\end{array}$ & $\begin{array}{c}0.900 \\
(1.567)\end{array}$ \\
\hline$L_{-} M a P P \_S h o c k_{t-1} \times \Delta^{4} R E R \_S h o c k_{t-1}$ & & & & $\begin{array}{c}\mathbf{0 . 8 0 7}^{* * *} \\
(0.264)\end{array}$ & & & & $\begin{array}{c}\text { 1.803*** } \\
(0.403)\end{array}$ & & & & $\begin{array}{c}\mathbf{0 . 7 1 8}^{* * *} \\
(0.205)\end{array}$ \\
\hline Observations & 3,505 & 3,505 & 3,505 & 3,505 & 3,505 & 3,505 & 3,505 & 3,505 & 3,505 & 3,505 & 3,505 & 3,505 \\
\hline \# of Economies & 62 & 62 & 62 & 62 & 62 & 62 & 62 & 62 & 62 & 62 & 62 & 62 \\
\hline
\end{tabular}

Source: Authors' calculations.

Note: Robust standard errors in parentheses. ${ }^{* * *} p<0.01,{ }^{* *} p<0.05,{ }^{*} p<0.1$ 
Table 12. Effectiveness of Macroprudential Policies by Individual Instrument

\begin{tabular}{|c|c|c|c|c|c|c|c|c|c|c|c|c|c|c|c|c|c|}
\hline & \multirow{2}{*}{$\begin{array}{l}\text { iMaPP } \\
\text { iMaPP }\end{array}$} & \multicolumn{2}{|c|}{$\begin{array}{l}\text { Borrower- } \\
\text { based tools }\end{array}$} & \multicolumn{13}{|c|}{ Financial institutions-based tools } & \multirow{3}{*}{$\begin{array}{l}\text { Other } \\
\text { От } \\
\text { (17) }\end{array}$} \\
\hline & & LTV & DSTI & CCB & LVR & Capital & $\begin{array}{c}\text { Conserv } \\
\text { ation }\end{array}$ & LLP & LFC & $\operatorname{Tax}$ & LTD & LCG & LoanR & Liquidity & RR & LFX & \\
\hline & (1) & (2) & (3) & (4) & (5) & (6) & (7) & (8) & (9) & (10) & (11) & (12) & (13) & (14) & (15) & (16) & \\
\hline \multicolumn{18}{|c|}{ Use MaPP Stance (same setup in Baseline) } \\
\hline \multirow[t]{2}{*}{$\Delta^{4} R E R_{t-1}$} & $-0.054^{\star \star *}$ & $-0.055^{\star \star \star}$ & $-0.061^{\star \star \star}$ & $-0.057^{\star \star \star}$ & $-0.058^{\star * *}$ & $-0.055^{\star \star \star}$ & $-0.056^{\star \star \star}$ & $-0.057^{\star \star \star}$ & $\star-0.049^{\star \star *}$ & $-0.056^{\star \star *}$ & $\star-0.054^{\star \star \star}$ & $-0.053^{\star * *}$ & $-0.053^{\star \star *}$ & $-0.055^{\star \star \star}$ & $-0.059^{* * \star}$ & ${ }^{\star}-0.058^{\star \star \star}$ & $-0.058^{\star \star \star}$ \\
\hline & $(0.018)$ & $(0.019)$ & $(0.021)$ & $(0.020)$ & $(0.020)$ & $(0.021)$ & $(0.022)$ & $(0.021)$ & $(0.017)$ & $(0.020)$ & $(0.021)$ & $(0.020)$ & $(0.018)$ & $(0.017)$ & $(0.022)$ & $(0.021)$ & $(0.022)$ \\
\hline \multirow[t]{2}{*}{$\operatorname{MaPP}_{t-1}$} & -0.737 & $-2.852^{\star \star}$ & -3.056 & -1.754 & -10.757 & -2.920 & -3.817 & 0.328 & -19.412 & 2.482 & -12.841 & -3.342 & 0.370 & $-7.331^{* *}$ & 1.511 & -5.319 & -2.090 \\
\hline & $(0.461)$ & (1.196) & $(2.149)$ & $(4.620)$ & $(9.850)$ & (2.278) & $(5.637)$ & $(4.414)$ & (22.121) & $(2.545)$ & (8.859) & $(4.203)$ & $(1.947)$ & $(2.876)$ & (1.322) & $(8.622)$ & (3.379) \\
\hline \multirow[t]{2}{*}{$\operatorname{MaPP}_{t-1} \times \Delta^{4} R E R_{t-1}$} & $0.144^{* * *}$ & $0.370^{* \star}$ & 0.499 & 0.416 & 1.766 & 0.291 & 0.111 & 0.943 & -2.750 & -0.327 & -0.867 & 0.207 & $0.128^{\star}$ & 0.205 & 0.122 & 1.222 & 0.406 \\
\hline & $(0.048)$ & $(0.168)$ & $(0.329)$ & $(0.409)$ & $(1.323)$ & $(0.307)$ & (0.198) & $(0.585)$ & (3.993) & $(0.394)$ & (2.655) & $(0.411)$ & $(0.069)$ & $(0.507)$ & (0.099) & $(1.213)$ & $(0.560)$ \\
\hline \multirow[t]{2}{*}{$\Delta^{4} R E R_{t-1}$} & $-0.052^{\star \star *}$ & $-0.055^{\star \star *}$ & $-0.056^{\star \star}$ & $-0.062^{\star \star *}$ & $-0.058^{\star * *}$ & $-0.063^{\star * *}$ & $-0.054^{\star *}$ & $-0.052^{* \star *}$ & ${ }^{*}-0.054^{\star * *}$ & $-0.055^{* *}$ & $-0.056^{\star \star *}$ & $-0.053^{\star * *}$ & $-0.052^{\star \star *}$ & $-0.054^{\star * *}$ & $-0.058^{\star *}$ & $-0.056^{\star \star *}$ & $-0.059^{\star \star \star}$ \\
\hline & $(0.019)$ & $(0.019)$ & $(0.023)$ & $(0.020)$ & $(0.020)$ & $(0.020)$ & $(0.021)$ & $(0.019)$ & $(0.019)$ & $(0.022)$ & $(0.020)$ & (0.019) & $(0.018)$ & $(0.016)$ & $(0.026)$ & $(0.019)$ & $(0.021)$ \\
\hline \multirow[t]{2}{*}{$T_{-} M a P P_{t-1}$} & $-0.852^{\star}$ & -2.195 & $-4.124^{*}$ & 1.585 & -10.757 & -2.022 & -3.713 & 7.282 & -27.235 & 2.957 & -19.571 & -7.095 & -2.658 & $-7.501^{*}$ & 1.547 & -6.584 & -4.685 \\
\hline & $(0.503)$ & (2.164) & $(2.275)$ & $(6.711)$ & $(9.850)$ & (2.209) & $(6.173)$ & $(5.797)$ & (31.534) & $(2.887)$ & (15.316) & (6.152) & (2.562) & (3.958) & $(1.777)$ & (9.783) & $(4.677)$ \\
\hline \multirow[t]{2}{*}{$T_{-} M a P P_{t-1} \times \Delta^{4} R E R_{t-1}$} & $0.130^{\star \star}$ & $0.420^{\star \star}$ & $0.464^{*}$ & 1.935 & 1.766 & 0.497 & 0.222 & $1.064^{\star}$ & -3.163 & -0.438 & 0.187 & -0.271 & -0.178 & 0.447 & 0.098 & 1.391 & 0.096 \\
\hline & $(0.061)$ & $(0.209)$ & $(0.275)$ & (1.398) & $(1.323)$ & $(0.390)$ & $(0.360)$ & $(0.590)$ & $(4.350)$ & $(0.478)$ & (3.231) & $(0.613)$ & $(0.251)$ & $(0.614)$ & $(0.180)$ & $(1.410)$ & $(0.630)$ \\
\hline \multirow[t]{2}{*}{$L_{-} M a P P_{t-1}$} & -0.630 & $-4.035^{\star *}$ & 12.817 & 20.394 & 0.000 & -13.453 & -18.346 & -19.544 & 7.114 & 43.257 & 0.466 & 0.440 & 4.712 & -4.985 & 1.446 & 2.674 & \\
\hline & $(0.709)$ & $(1.724)$ & (11.959) & (108.692) & $(0.000)$ & (9.666) & $(41.921)$ & $(17.403)$ & $(19.691)$ & $(48.675)$ & $(16.042)$ & $(6.333)$ & (6.912) & $(4.395)$ & $(1.723)$ & $(32.135)$ & . \\
\hline \multirow[t]{2}{*}{$L_{-} M a P P_{t-1} \times \Delta^{4} R E R_{t-1}$} & $0.159^{\star \star \star}$ & 0.200 & 0.546 & -3.848 & 0.000 & -1.051 & -2.770 & 2.506 & -0.102 & 0.554 & -5.596 & 0.203 & -0.031 & -0.211 & 0.152 & 6.953 & 4.452 \\
\hline & $(0.042)$ & $(0.250)$ & $(0.740)$ & $(10.355)$ & $(0.000)$ & $(0.867)$ & $(7.201)$ & $(1.844)$ & $(4.359)$ & $(2.267)$ & (8.985) & $(0.508)$ & $(0.271)$ & $(1.010)$ & $(0.180)$ & $(10.345)$ & $(4.733)$ \\
\hline \# of Overall MaPP Actions & 417 & 58 & 28 & 5 & 13 & 91 & 30 & 27 & 13 & 30 & 1 & 1 & 30 & 34 & 20 & 16 & 20 \\
\hline \# of Tightening Actions & 758 & 93 & 37 & 7 & 13 & 116 & 32 & 41 & 17 & 33 & 7 & 10 & 40 & 49 & 218 & 24 & 21 \\
\hline \# of Loosening Actions & 341 & 35 & 9 & 2 & 0 & 25 & 2 & 14 & 4 & 3 & 6 & 9 & 10 & 15 & 198 & 8 & 1 \\
\hline Observations & 3,842 & 3,842 & 3,842 & 3,842 & 3,842 & 3,842 & 3,842 & 3,842 & 3,842 & 3,842 & 3,842 & 3,842 & 3,842 & 3,842 & 3,842 & 3,842 & 3,842 \\
\hline \# of Economies & 62 & 62 & 62 & 62 & 62 & 62 & 62 & 62 & 62 & 62 & 62 & 62 & 62 & 62 & 62 & 62 & 62 \\
\hline
\end{tabular}

Source: Authors' calculations.

Note: (a) Standard errors in parentheses. ${ }^{* * *} p<0.01,{ }^{* *} p<0.05,{ }^{*} p<0.1$

(b) The coefficient of loosening action of "other" tools is omitted due to its insufficient action number, as indicated in the table. 


\section{Table 13. Leakages and the "Walls" Effect of Capital Controls}

\section{3(a) The Fixed Effect Model}

\begin{tabular}{|c|c|c|c|c|c|c|c|c|c|c|c|c|c|}
\hline \multirow{3}{*}{ Variables } & \multirow{3}{*}{$\begin{array}{c}\text { Baseline } \\
\begin{array}{c}\text { (1) } \\
\text { FE }\end{array}\end{array}$} & \multicolumn{4}{|c|}{ iMaPP } & \multicolumn{4}{|c|}{ Borrower-based tools } & \multicolumn{4}{|c|}{ Financial institutions-based tools } \\
\hline & & (2) & (3) & (4) & (5) & (6) & (7) & (8) & (9) & $(10)$ & (11) & (12) & (13) \\
\hline & & $\mathrm{FE}$ & $\mathrm{FE}$ & $\mathrm{FE}$ & $\mathrm{FE}$ & $\mathrm{FE}$ & $\mathrm{FE}$ & $\mathrm{FE}$ & $\mathrm{FE}$ & $\mathrm{FE}$ & $\mathrm{FE}$ & $\mathrm{FE}$ & $\mathrm{FE}$ \\
\hline \multicolumn{14}{|c|}{ The "Walls" Effect of Capital Controls + MaPP } \\
\hline \multirow[t]{3}{*}{ CFLOW $_{t-1}$} & $0.713^{* \star *}$ & $0.713^{* * *}$ & $0.711^{* \star *}$ & $0.713^{\star * *}$ & $0.713^{* \star *}$ & $0.713^{* * *}$ & $0.711^{* * *}$ & $0.713^{* * *}$ & $0.713^{* \star *}$ & $0.713^{\star * \star}$ & $0.711^{* \star *}$ & $0.713^{* * *}$ & $0.713^{* \star *}$ \\
\hline & $(0.032)$ & $(0.032)$ & $(0.032)$ & $(0.032)$ & $(0.033)$ & $(0.032)$ & $(0.032)$ & $(0.032)$ & $(0.032)$ & $(0.032)$ & $(0.032)$ & $(0.032)$ & $(0.032)$ \\
\hline & 0.713 & 0.713 & 0.711 & 0.713 & 0.713 & 0.713 & 0.711 & 0.712 & 0.712 & 0.712 & 0.711 & 0.712 & 0.712 \\
\hline \multirow[t]{3}{*}{$Y_{t-1}$} & $0.091^{\star *}$ & $0.090^{* *}$ & $0.128^{* *}$ & $0.088^{* *}$ & $0.103^{*}$ & $0.089^{* *}$ & $0.126^{\star *}$ & $0.086^{\star \star}$ & $0.102^{\star}$ & $0.091^{\star *}$ & $0.129^{\star *}$ & $0.092^{* *}$ & $0.104^{\star}$ \\
\hline & $(0.037)$ & $(0.037)$ & $(0.044)$ & $(0.037)$ & $(0.048)$ & $(0.037)$ & $(0.045)$ & $(0.036)$ & $(0.048)$ & $(0.037)$ & $(0.044)$ & $(0.038)$ & $(0.048)$ \\
\hline & 0.057 & 0.057 & 0.081 & 0.055 & 0.065 & 0.056 & 0.080 & 0.054 & 0.065 & 0.058 & 0.082 & 0.058 & 0.066 \\
\hline \multirow[t]{3}{*}{$F A R I_{t-1}$} & $-4.933^{*}$ & $-5.004^{*}$ & $-6.116^{*}$ & $-5.014^{*}$ & $-5.218^{*}$ & $-5.161^{*}$ & $-6.251^{*}$ & $-5.298^{*}$ & $-5.378^{*}$ & $-4.907^{*}$ & $-6.034^{*}$ & $-4.919^{*}$ & $-5.127^{*}$ \\
\hline & $(2.341)$ & (2.356) & (3.110) & (2.346) & (2.419) $\mathrm{h}$ & h $\quad(2.386)$ & (3.144) & (2.403) & (2.459) & (2.342) & (3.114) & $(2.362)$ & (2.409) \\
\hline & -0.045 & -0.046 & -0.056 & -0.046 & -0.048 & -0.047 & -0.057 & -0.048 & -0.049 & -0.045 & -0.055 & -0.045 & -0.047 \\
\hline \multirow[t]{3}{*}{$\operatorname{MaPP}_{t-1}$} & & 0.144 & 0.130 & 0.091 & 0.134 & $1.474^{\star \star}$ & $1.443^{\star \star}$ & 1.159 & $1.466^{\star \star}$ & -0.076 & -0.090 & -0.048 & -0.089 \\
\hline & & $(0.096)$ & $(0.089)$ & $(0.189)$ & $(0.102)$ & $(0.461)$ & $(0.466)$ & $(0.656)$ & $(0.461)$ & $(0.169)$ & $(0.160)$ & $(0.172)$ & $(0.175)$ \\
\hline & & 0.004 & 0.004 & 0.003 & 0.004 & 0.044 & 0.043 & 0.035 & 0.044 & -0.002 & -0.003 & -0.001 & -0.003 \\
\hline \multirow[t]{3}{*}{$M P S_{t-1}$} & $0.174^{\star *}$ & $0.174^{\star \star}$ & $0.170^{\star \star}$ & $0.175^{\star *}$ & $0.165^{\star \star}$ & $0.176^{\star \star}$ & $0.171^{\star *}$ & $0.176^{\star \star}$ & $0.167^{\star \star}$ & $0.174^{\star *}$ & $0.169^{\star \star}$ & $0.173^{\star *}$ & $0.165^{\star \star}$ \\
\hline & $(0.074)$ & $(0.074)$ & $(0.071)$ & $(0.074)$ & $(0.071)$ & $(0.074)$ & $(0.072)$ & $(0.075)$ & $(0.072)$ & $(0.074)$ & $(0.071)$ & $(0.073)$ & $(0.071)$ \\
\hline & 0.047 & 0.047 & 0.046 & 0.048 & 0.045 & 0.048 & 0.047 & 0.048 & 0.045 & 0.047 & 0.046 & 0.047 & 0.045 \\
\hline \multirow[t]{3}{*}{$Y_{t-1} \times F A R I_{t-1}$} & & & $-0.110^{* *}$ & & & & $-0.107^{*}$ & & & & $-0.111^{* *}$ & & \\
\hline & & & $(0.048)$ & & & & $(0.049)$ & & & & $(0.048)$ & & \\
\hline & & & -0.031 & & & & -0.030 & & & & -0.031 & & \\
\hline \multirow[t]{3}{*}{$Y_{t-1} \times M a P P_{t-1}$} & & & & 0.021 & & & & 0.104 & & & & -0.017 & \\
\hline & & & & $(0.034)$ & & & & $(0.082)$ & & & & $(0.019)$ & \\
\hline & & & & 0.006 & & & & 0.029 & & & & -0.005 & \\
\hline \multirow[t]{3}{*}{$Y_{t-1} \times M P S_{t-1}$} & & & & & -0.004 & & & & -0.004 & & & & -0.004 \\
\hline & & & & & $(0.005)$ & & & & $(0.005)$ & & & & $(0.005)$ \\
\hline & & & & & -0.013 & & & & -0.013 & & & & -0.013 \\
\hline \multirow[t]{3}{*}{$\Delta^{4} F_{-} R G D P_{t-1}$} & 0.570 & 0.568 & 0.560 & 0.566 & 0.569 & 0.561 & 0.554 & 0.556 & 0.563 & 0.571 & 0.564 & 0.572 & 0.573 \\
\hline & $(0.366)$ & $(0.365)$ & $(0.358)$ & $(0.365)$ & $(0.360)$ & $(0.364)$ & $(0.357)$ & $(0.363)$ & $(0.359)$ & $(0.366)$ & $(0.359)$ & $(0.366)$ & $(0.361)$ \\
\hline & 0.074 & 0.074 & 0.073 & 0.073 & 0.074 & 0.073 & 0.072 & 0.072 & 0.073 & 0.074 & 0.073 & 0.074 & 0.074 \\
\hline \multirow[t]{2}{*}{ Constant } & 0.567 & 0.601 & 0.906 & 0.602 & 0.727 & 0.642 & 0.941 & 0.700 & 0.769 & 0.553 & 0.862 & 0.559 & 0.682 \\
\hline & $(2.358)$ & $(2.348)$ & (2.254) & (2.346) & (2.346) & (2.363) & (2.268) & $(2.355)$ & (2.362) & $(2.347)$ & (2.252) & $(2.347)$ & (2.345) \\
\hline Time-fixed Effect & Quarter & Quarter & Quarter & Quarter & Quarter & Quarter & Quarter & Quarter & Quarter & Quarter & Quarter & Quarter & Quarter \\
\hline Observations & 3,603 & 3,603 & 3,603 & 3,603 & 3,603 & 3,603 & 3,603 & 3,603 & 3,603 & 3,603 & 3,603 & 3,603 & 3,603 \\
\hline \# of Economies & 61 & 61 & 61 & 61 & 61 & 61 & 61 & 61 & 61 & 61 & 61 & 61 & 61 \\
\hline Overall R-square & 0.725 & 0.725 & 0.726 & 0.726 & 0.725 & 0.726 & 0.726 & 0.726 & 0.726 & 0.725 & 0.726 & 0.725 & 0.725 \\
\hline Within R-square & 0.631 & 0.631 & 0.631 & 0.631 & 0.631 & 0.632 & 0.632 & 0.632 & 0.632 & 0.631 & 0.631 & 0.631 & 0.631 \\
\hline
\end{tabular}

Source: Authors' calculations.

Note: (a) Standard errors in parentheses. ${ }^{* *} p<0.01,{ }^{* *} p<0.05,{ }^{*} p<0.1$

(b) We drop Taiwan POC in the sample due to missing data of financial account restriction index.

(c) The blue italic numbers are standardized coefficients, representing the change of standard deviation in the dependent variable by one standard deviation change in corresponding independent variables.

(d) Both of the capital inflows and capital control measures are based on the gross other investment inflows. 


\section{3(b) The Fixed Effect Model with Macroprudential Policy Shocks}

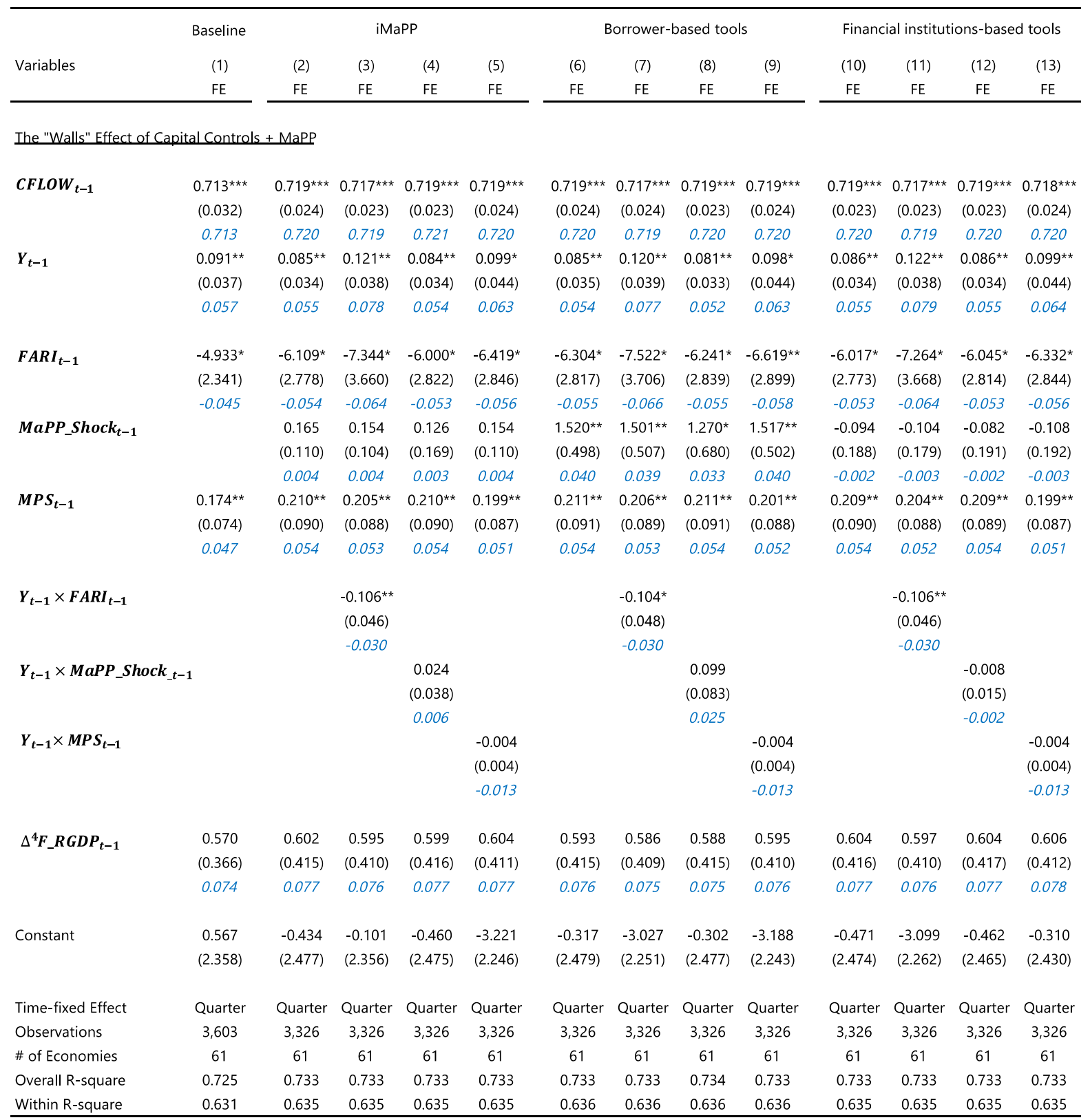

Source: Authors' calculations.

Note: (a) Standard errors in parentheses. ${ }^{* *} p<0.01,{ }^{* *} p<0.05,{ }^{*} p<0.1$

(b) We drop Taiwan POC in the sample due to missing data of financial account restriction index.

(c) The blue italic numbers are standardized coefficients, representing the change of standard deviation in the dependent variable by one standard deviation change in corresponding independent variables.

(d) Both of the capital inflows and capital control measures are based on the gross other investment inflows. 


\section{3(c) The Random Effect Model with Macroprudential Policy Shocks}

\begin{tabular}{|c|c|c|c|c|c|c|c|c|c|c|c|c|c|}
\hline \multirow{3}{*}{ Variables } & \multirow{3}{*}{$\begin{array}{c}\text { Baseline } \\
\begin{array}{c}(1) \\
\mathrm{RE} \\
\end{array}\end{array}$} & \multicolumn{4}{|c|}{ iMaPP } & \multicolumn{4}{|c|}{ Borrower-based tools } & \multicolumn{4}{|c|}{ Financial institutions-based tools } \\
\hline & & (2) & (3) & (4) & (5) & (6) & (7) & (8) & (9) & (10) & (11) & (12) & (13) \\
\hline & & RE & RE & RE & RE & RE & RE & RE & $\mathrm{RE}$ & RE & $\mathrm{RE}$ & RE & RE \\
\hline \multicolumn{14}{|c|}{ The "Walls" Effect of Capital Controls + MaPP } \\
\hline \multirow[t]{3}{*}{$C F L O W_{-} D M_{t-1}$} & $0.721^{* * *}$ & $0.729^{\star \star *}$ & $0.728^{\star \star \star *}$ & $0.729^{\star * *}$ & $0.729^{\star * \star *}$ & 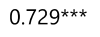 & $0.728^{\star * \star}$ & $0.729^{* \star *}$ & $0.729^{\star \star *}$ & $0.728^{\star \star *}$ & $0.727^{* \star *}$ & $0.728^{* \star \star}$ & $0.729^{* * *}$ \\
\hline & $(0.032)$ & $(0.025)$ & $(0.025)$ & $(0.025)$ & $(0.025)$ & $(0.025)$ & $(0.025)$ & $(0.025)$ & $(0.025)$ & $(0.025)$ & $(0.025)$ & $(0.025)$ & $(0.025)$ \\
\hline & 0.726 & 0.728 & 0.727 & 0.728 & 0.728 & 0.728 & 0.727 & 0.728 & 0.728 & 0.728 & 0.727 & 0.728 & 0.728 \\
\hline \multirow[t]{3}{*}{$Y_{t-1}$} & $0.069^{* * *}$ & $0.067^{* * *}$ & $0.088^{* * *}$ & $0.065^{* * *}$ & $0.066^{\star * *}$ & $0.067^{\star \star \star}$ & $0.087^{* * *}$ & $0.063^{* * *}$ & $0.065^{\star * *}$ & $0.067^{\star \star \star}$ & $0.088^{* * *}$ & $0.068^{\star \star \star}$ & $0.066^{\star \star *}$ \\
\hline & $(0.024)$ & $(0.022)$ & $(0.026)$ & $(0.022)$ & $(0.022)$ & $(0.023)$ & $(0.027)$ & $(0.022)$ & $(0.022)$ & $(0.023)$ & $(0.026)$ & $(0.022)$ & $(0.022)$ \\
\hline & 0.054 & 0.053 & 0.070 & 0.052 & 0.052 & 0.053 & 0.069 & 0.050 & 0.051 & 0.053 & 0.070 & 0.054 & 0.052 \\
\hline \multirow{3}{*}{$F A R I_{t-1}$} & $-2.723^{*}$ & -2.718 & -3.000 & -2.665 & -2.710 & -2.751 & -3.025 & -2.681 & -2.742 & -2.697 & -2.981 & -2.713 & -2.688 \\
\hline & (1.574) & $(1.748)$ & (2.028) & $(1.750)$ & $(1.763)$ & $(1.747)$ & $(2.026)$ & $(1.731)$ & $(1.760)$ & $(1.748)$ & (2.032) & (1.776) & $(1.762)$ \\
\hline & -0.031 & -0.029 & -0.032 & -0.029 & -0.029 & -0.030 & -0.033 & -0.029 & -0.030 & -0.029 & -0.032 & -0.029 & -0.029 \\
\hline \multirow{3}{*}{ MaPP_Shock t-1 $_{1}$} & & 0.138 & 0.129 & 0.101 & 0.137 & $1.487^{\star \star \star}$ & $1.471^{\star \star \star}$ & $1.241^{*}$ & $1.488^{\star \star \star}$ & -0.121 & -0.128 & -0.107 & -0.122 \\
\hline & & $(0.110)$ & $(0.107)$ & $(0.162)$ & $(0.112)$ & $(0.495)$ & $(0.500)$ & $(0.638)$ & $(0.496)$ & $(0.184)$ & $(0.179)$ & $(0.184)$ & $(0.187)$ \\
\hline & & 0.004 & 0.004 & 0.003 & 0.004 & 0.048 & 0.047 & 0.040 & 0.048 & -0.004 & -0.004 & -0.003 & -0.004 \\
\hline \multirow[t]{3}{*}{$M P S_{-} D M_{t-1}$} & $0.156^{\star \star}$ & $0.179 * *$ & $0.176^{\star \star}$ & $0.180^{* *}$ & $0.178^{* *}$ & $0.180^{* *}$ & $0.178^{* *}$ & $0.180^{* *}$ & $0.180^{* *}$ & $0.179 * *$ & $0.176^{\star *}$ & $0.178^{\star *}$ & $0.178^{\star *}$ \\
\hline & $(0.071)$ & $(0.077)$ & $(0.077)$ & $(0.077)$ & $(0.078)$ & $(0.079)$ & $(0.078)$ & $(0.079)$ & $(0.080)$ & $(0.077)$ & $(0.076)$ & $(0.077)$ & $(0.078)$ \\
\hline & 0.032 & 0.035 & 0.034 & 0.035 & 0.035 & 0.035 & 0.034 & 0.035 & 0.035 & 0.035 & 0.034 & 0.034 & 0.034 \\
\hline \multirow[t]{3}{*}{$Y_{t-1} \times F A R I_{t-1}$} & & & $-0.061^{\star}$ & & & & $-0.059 *$ & & & & $-0.062^{*}$ & & \\
\hline & & & $(0.035)$ & & & & $(0.035)$ & & & & $(0.035)$ & & \\
\hline & & & -0.021 & & & & -0.021 & & & & -0.022 & & \\
\hline \multirow[t]{3}{*}{$Y_{t-1} \times M a P P \_S h o c k_{t-1}$} & & & & 0.023 & & & & 0.096 & & & & -0.010 & \\
\hline & & & & $(0.035)$ & & & & $(0.080)$ & & & & $(0.014)$ & \\
\hline & & & & 0.007 & & & & 0.030 & & & & -0.003 & \\
\hline \multirow[t]{3}{*}{$Y_{t-1} \times M P S_{-} D M_{t-1}$} & & & & & -0.001 & & & & -0.001 & & & & -0.001 \\
\hline & & & & & $(0.005)$ & & & & $(0.005)$ & & & & $(0.005)$ \\
\hline & & & & & -0.002 & & & & -0.002 & & & & -0.002 \\
\hline \multirow[t]{3}{*}{$\Delta^{4} F_{-} R G D P_{t-1}$} & 0.354 & 0.365 & 0.362 & 0.363 & 0.365 & 0.359 & 0.356 & 0.355 & 0.360 & 0.367 & 0.363 & 0.367 & 0.367 \\
\hline & $(0.235)$ & $(0.258)$ & $(0.257)$ & $(0.259)$ & $(0.257)$ & $(0.258)$ & $(0.257)$ & $(0.259)$ & $(0.257)$ & $(0.259)$ & $(0.258)$ & $(0.260)$ & $(0.258)$ \\
\hline & 0.056 & 0.057 & 0.057 & 0.057 & 0.058 & 0.057 & 0.056 & 0.056 & 0.057 & 0.058 & 0.057 & 0.058 & 0.058 \\
\hline \multirow[t]{3}{*}{ Avg Credit/GDP } & 0.003 & 0.003 & 0.002 & 0.003 & 0.003 & 0.003 & 0.002 & 0.003 & 0.003 & 0.003 & 0.002 & 0.003 & 0.003 \\
\hline & $(0.003)$ & $(0.003)$ & $(0.002)$ & $(0.003)$ & $(0.002)$ & $(0.003)$ & $(0.002)$ & $(0.003)$ & $(0.002)$ & $(0.003)$ & $(0.002)$ & $(0.003)$ & $(0.002)$ \\
\hline & 0.009 & 0.011 & 0.008 & 0.011 & 0.011 & 0.010 & 0.008 & 0.010 & 0.011 & 0.011 & 0.008 & 0.011 & 0.011 \\
\hline \multirow[t]{2}{*}{ Constant } & 1.482 & 1.496 & 1.666 & 1.457 & 1.494 & 1.590 & 1.755 & 1.538 & 1.587 & 1.499 & 1.672 & 1.508 & 1.496 \\
\hline & $(1.617)$ & $(1.623)$ & $(1.730)$ & $(1.633)$ & $(1.626)$ & (1.637) & $(1.748)$ & (1.625) & (1.639) & (1.618) & $(1.725)$ & (1.625) & $(1.620)$ \\
\hline Time-fixed Effect & Quarter & Quarter & Quarter & Quarter & Quarter & Quarter & Quarter & Quarter & Quarter & Quarter & Quarter & Quarter & Quarter \\
\hline Observations & 3,603 & 3,326 & 3,326 & 3,326 & 3,326 & 3,326 & 3,326 & 3,326 & 3,326 & 3,326 & 3,326 & 3,326 & 3,326 \\
\hline \# of Economies & 61 & 61 & 61 & 61 & 61 & 61 & 61 & 61 & 61 & 61 & 61 & 61 & 61 \\
\hline Overall R-square & 0.629 & 0.635 & 0.635 & 0.635 & 0.635 & 0.636 & 0.636 & 0.636 & 0.636 & 0.635 & 0.635 & 0.635 & 0.635 \\
\hline
\end{tabular}

Source: Authors' calculations.

Note: (a) Standard errors in parentheses. ${ }^{* *} p<0.01,{ }^{* *} p<0.05,{ }^{*} p<0.1$

(b) We drop Taiwan POC in the sample due to missing data of financial account restriction index.

(c) The blue italic numbers are standardized coefficients, representing the change of standard deviation in the dependent variable by one standard deviation change in corresponding independent variables.

(d) Both of the capital inflows and capital control measures are based on the gross other investment inflows. 
Table 14. Leakages and the "Gates" Effect of Capital Controls

14(a) The Fixed Effect Model

\begin{tabular}{|c|c|c|c|c|c|c|c|c|c|c|c|c|c|}
\hline \multirow{3}{*}{ Variables } & \multirow{3}{*}{$\begin{array}{c}\text { Baseline } \\
\text { (1) } \\
\text { FE }\end{array}$} & \multicolumn{4}{|c|}{ iMaPP } & \multicolumn{4}{|c|}{ Borrower-based tools } & \multicolumn{4}{|c|}{ Financial institutions-based tools } \\
\hline & & (2) & (3) & (4) & (5) & (6) & (7) & (8) & (9) & (10) & (11) & (12) & (13) \\
\hline & & $\mathrm{FE}$ & $\mathrm{FE}$ & $\mathrm{FE}$ & $\mathrm{FE}$ & $\mathrm{FE}$ & $\mathrm{FE}$ & $\mathrm{FE}$ & $\mathrm{FE}$ & $\mathrm{FE}$ & $\mathrm{FE}$ & $\mathrm{FE}$ & $\mathrm{FE}$ \\
\hline \multicolumn{14}{|c|}{ The "Gates" Effect of Capital Controls + MaPP } \\
\hline \multirow[t]{3}{*}{ CFLOW $_{t-1}$} & $0.718^{\star \star \star}$ & $0.719^{\star * *}$ & $0.719^{\star * *}$ & $0.719^{\star * \star}$ & $0.718^{\star * *}$ & $0.718^{* * *}$ & $0.718^{* * *}$ & $0.718^{\star \star \star}$ & $0.718^{* * *}$ & $0.718^{* \star *}$ & $0.718^{\star \star *}$ & $0.718^{\star * *}$ & $0.718^{* * *}$ \\
\hline & $(0.035)$ & $(0.035)$ & $(0.035)$ & $(0.035)$ & $(0.036)$ & $(0.035)$ & $(0.035)$ & $(0.035)$ & $(0.036)$ & $(0.035)$ & $(0.035)$ & $(0.036)$ & $(0.036)$ \\
\hline & 0.719 & 0.719 & 0.719 & 0.719 & 0.719 & 0.719 & 0.719 & 0.718 & 0.718 & 0.719 & 0.719 & 0.718 & 0.718 \\
\hline \multirow[t]{3}{*}{$Y_{t-1}$} & $0.097^{\star *}$ & $0.096^{\star *}$ & $0.097^{\star \star}$ & $0.095^{\star \star}$ & $0.106^{\star \star}$ & $0.096^{\star \star}$ & $0.096^{\star \star}$ & $0.093^{\star *}$ & $0.105^{\star \star}$ & $0.097^{\star *}$ & $0.097^{\star *}$ & $0.099^{* *}$ & $0.107^{\star *}$ \\
\hline & $(0.033)$ & $(0.033)$ & $(0.033)$ & $(0.034)$ & $(0.041)$ & $(0.033)$ & $(0.034)$ & $(0.033)$ & $(0.041)$ & $(0.033)$ & $(0.033)$ & $(0.034)$ & $(0.041)$ \\
\hline & 0.064 & 0.064 & 0.064 & 0.063 & 0.071 & 0.064 & 0.064 & 0.062 & 0.070 & 0.065 & 0.065 & 0.066 & 0.071 \\
\hline \multirow[t]{3}{*}{$\triangle F A R I_{t-1}$} & -0.318 & $-0.352^{*}$ & -0.338 & $-0.342^{*}$ & $-0.344^{*}$ & $-0.345^{\star}$ & -0.327 & $-0.367^{*}$ & $-0.340^{*}$ & $-0.294^{*}$ & -0.278 & -0.307 & $-0.286^{*}$ \\
\hline & $(0.184)$ & $(0.180)$ & $(0.207)$ & $(0.173)$ & $(0.171)$ & $(0.175)$ & $(0.205)$ & $(0.174)$ & $(0.167)$ & $(0.159)$ & $(0.183)$ & $(0.169)$ & $(0.150)$ \\
\hline & -0.005 & -0.005 & -0.005 & -0.005 & -0.005 & -0.005 & -0.005 & -0.006 & -0.005 & -0.004 & -0.004 & -0.005 & -0.004 \\
\hline \multirow[t]{3}{*}{$M a P P_{t-1}$} & & 0.111 & 0.110 & 0.077 & 0.101 & $1.303^{* *}$ & $1.306^{\star *}$ & 0.984 & $1.294^{\star \star}$ & -0.087 & -0.088 & -0.057 & -0.099 \\
\hline & & $(0.070)$ & $(0.069)$ & $(0.129)$ & $(0.074)$ & $(0.519)$ & $(0.517)$ & $(0.590)$ & $(0.512)$ & $(0.156)$ & $(0.152)$ & $(0.147)$ & $(0.164)$ \\
\hline & & 0.003 & 0.003 & 0.002 & 0.003 & 0.039 & 0.040 & 0.030 & 0.039 & -0.003 & -0.003 & -0.002 & -0.003 \\
\hline \multirow[t]{3}{*}{$M P S_{t-1}$} & $0.161^{*}$ & $0.161^{*}$ & $0.161^{*}$ & $0.162^{*}$ & $0.150^{*}$ & $0.162^{*}$ & $0.162^{*}$ & $0.161^{\star}$ & $0.152^{*}$ & $0.161^{*}$ & $0.161^{\star}$ & $0.160^{\star}$ & $0.150^{*}$ \\
\hline & $(0.076)$ & $(0.076)$ & $(0.076)$ & $(0.076)$ & $(0.073)$ & $(0.077)$ & $(0.077)$ & $(0.077)$ & $(0.074)$ & $(0.076)$ & $(0.076)$ & $(0.075)$ & $(0.073)$ \\
\hline & 0.045 & 0.045 & 0.045 & 0.045 & 0.042 & 0.045 & 0.046 & 0.045 & 0.043 & 0.045 & 0.045 & 0.045 & 0.042 \\
\hline \multirow[t]{3}{*}{$Y_{t-1} \times \Delta F A R I_{t-1}$} & & & -0.012 & & & & -0.015 & & & & -0.013 & & \\
\hline & & & $(0.028)$ & & & & $(0.027)$ & & & & $(0.028)$ & & \\
\hline & & & -0.002 & & & & -0.002 & & & & -0.002 & & \\
\hline \multirow[t]{3}{*}{$Y_{t-1} \times M a P P_{t-1}$} & & & & 0.015 & & & & 0.105 & & & & -0.023 & \\
\hline & & & & $(0.026)$ & & & & $(0.076)$ & & & & $(0.016)$ & \\
\hline & & & & 0.004 & & & & 0.030 & & & & -0.007 & \\
\hline \multirow[t]{3}{*}{$Y_{t-1} \times M P S_{t-1}$} & & & & & -0.003 & & & & -0.003 & & & & -0.003 \\
\hline & & & & & $(0.004)$ & & & & $(0.004)$ & & & & $(0.004)$ \\
\hline & & & & & -0.010 & & & & -0.010 & & & & -0.011 \\
\hline \multirow[t]{3}{*}{$\Delta^{4} F_{-} R G D P_{t-1}$} & 0.494 & 0.491 & 0.490 & 0.490 & 0.493 & 0.485 & 0.483 & 0.478 & 0.486 & 0.495 & 0.494 & 0.495 & 0.497 \\
\hline & $(0.368)$ & $(0.367)$ & $(0.367)$ & $(0.368)$ & $(0.363)$ & $(0.367)$ & $(0.366)$ & $(0.366)$ & $(0.363)$ & $(0.368)$ & $(0.367)$ & $(0.368)$ & $(0.364)$ \\
\hline & 0.064 & 0.064 & 0.063 & 0.063 & 0.064 & 0.063 & 0.063 & 0.062 & 0.063 & 0.064 & 0.064 & 0.064 & 0.064 \\
\hline \multirow[t]{2}{*}{ Constant } & -2.554 & -2.541 & -2.539 & -2.545 & -2.454 & -2.534 & -2.532 & -2.504 & -2.448 & -2.563 & -2.561 & -2.551 & -2.474 \\
\hline & (1.815) & $(1.814)$ & $(1.815)$ & $(1.815)$ & $(1.779)$ & $(1.808)$ & $(1.808)$ & $(1.804)$ & $(1.772)$ & $(1.814)$ & $(1.814)$ & $(1.805)$ & (1.779) \\
\hline Time-fixed Effect & Quarter & Quarter & Quarter & Quarter & Quarter & Quarter & Quarter & Quarter & Quarter & Quarter & Quarter & Quarter & Quarter \\
\hline Observations & 3,783 & 3,783 & 3,783 & 3,783 & 3,783 & 3,783 & 3,783 & 3,783 & 3,783 & 3,783 & 3,783 & 3,783 & 3,783 \\
\hline \# of Economies & 61 & 61 & 61 & 61 & 61 & 61 & 61 & 61 & 61 & 61 & 61 & 61 & 61 \\
\hline Overall R-square & 0.724 & 0.724 & 0.724 & 0.724 & 0.724 & 0.725 & 0.725 & 0.725 & 0.725 & 0.724 & 0.724 & 0.724 & 0.724 \\
\hline Within R-square & 0.633 & 0.633 & 0.633 & 0.633 & 0.633 & 0.634 & 0.634 & 0.634 & 0.634 & 0.633 & 0.633 & 0.633 & 0.633 \\
\hline
\end{tabular}

Source: Authors' calculations.

Note: (a) Standard errors in parentheses. ${ }^{* * *} p<0.01,{ }^{* *} p<0.05,{ }^{*} p<0.1$

(b) We drop Taiwan POC in the sample due to missing data of financial account restriction index.

(c) The blue italic numbers are standardized coefficients, representing the change of standard deviation in the dependent variable by one standard deviation change in corresponding independent variables.

(d) Both of the capital inflows and capital control measures are based on the gross other investment inflows. 


\section{4(b) The Fixed Effect Model with Macroprudential Policy Shocks and Capital} Control Shocks

\begin{tabular}{|c|c|c|c|c|c|c|c|c|c|c|c|c|c|}
\hline \multirow{3}{*}{ Variables } & \multirow{2}{*}{$\begin{array}{c}\text { Baseline } \\
\text { (1) }\end{array}$} & \multicolumn{4}{|c|}{ iMaPP } & \multicolumn{4}{|c|}{ Borrower-based tools } & \multicolumn{4}{|c|}{ Financial institutions-based tools } \\
\hline & & (2) & (3) & (4) & (5) & (6) & $(7)$ & $(8)$ & (9) & $(10)$ & $(11)$ & $(12)$ & (13) \\
\hline & $\mathrm{FE}$ & $\mathrm{FE}$ & $\mathrm{FE}$ & $\mathrm{FE}$ & $\mathrm{FE}$ & $\mathrm{FE}$ & $\mathrm{FE}$ & $\mathrm{FE}$ & $\mathrm{FE}$ & $\mathrm{FE}$ & $\mathrm{FE}$ & $\mathrm{FE}$ & $\mathrm{FE}$ \\
\hline \multicolumn{14}{|c|}{ The "Gates" Effect of Capital Controls + MaPP } \\
\hline \multirow[t]{3}{*}{$\operatorname{CFLOW}_{t-1}$} & $0.725^{\star \star \star}$ & $0.725^{\star \star *}$ & $0.725^{\star \star \star}$ & $0.725^{\star \star \star}$ & $0.725^{\star \star \star}$ & $0.725^{\star \star \star}$ & $0.725^{\star \star \star}$ & $0.725^{\star \star \star}$ & $0.725^{\star \star \star}$ & $0.725^{\star \star \star}$ & $0.725^{\star \star \star}$ & $0.725^{\star \star \star}$ & $0.725^{\star \star \star}$ \\
\hline & $(0.028)$ & $(0.028)$ & $(0.028)$ & $(0.028)$ & $(0.028)$ & $(0.028)$ & $(0.028)$ & $(0.028)$ & $(0.028)$ & $(0.028)$ & $(0.028)$ & $(0.028)$ & $(0.028)$ \\
\hline & 0.728 & 0.728 & 0.728 & 0.728 & 0.728 & 0.728 & 0.728 & 0.728 & 0.728 & 0.727 & 0.727 & 0.727 & 0.727 \\
\hline \multirow[t]{3}{*}{$Y_{t-1}$} & $0.094^{\star *}$ & $0.094^{\star \star}$ & $0.094^{\star \star}$ & $0.092^{\star \star}$ & $0.103^{\star *}$ & $0.093^{\star *}$ & $0.094^{\star \star}$ & $0.090^{\star \star}$ & $0.102^{\star \star}$ & $0.094^{\star *}$ & $0.094^{\star \star}$ & $0.094^{\star *}$ & $0.103^{\star *}$ \\
\hline & $(0.029)$ & $(0.029)$ & $(0.029)$ & $(0.030)$ & $(0.037)$ & $(0.030)$ & $(0.030)$ & $(0.029)$ & $(0.037)$ & $(0.029)$ & $(0.029)$ & $(0.030)$ & $(0.037)$ \\
\hline & 0.063 & 0.063 & 0.064 & 0.062 & 0.069 & 0.063 & 0.063 & 0.061 & 0.069 & 0.063 & 0.064 & 0.064 & 0.070 \\
\hline \multirow{3}{*}{$\Delta F A R I$ Shock $k_{t-1}$} & -0.295 & -0.321 & -0.279 & -0.305 & $-0.313^{*}$ & $-0.336^{\star}$ & -0.286 & $-0.371^{*}$ & $-0.330^{*}$ & -0.268 & -0.222 & -0.276 & -0.260 \\
\hline & (0.191) & $(0.180)$ & $(0.227)$ & $(0.167)$ & $(0.170)$ & $(0.177)$ & $(0.229)$ & $(0.177)$ & $(0.168)$ & (0.173) & $(0.212)$ & $(0.181)$ & $(0.163)$ \\
\hline & -0.003 & -0.004 & -0.003 & -0.003 & -0.004 & -0.004 & -0.003 & -0.004 & -0.004 & -0.003 & -0.003 & -0.003 & -0.003 \\
\hline \multirow[t]{3}{*}{ MaPP_Shock ${ }_{t-1}$} & & 0.116 & 0.114 & 0.088 & 0.107 & $1.335^{\star \star}$ & $1.341^{\star \star}$ & 1.068 & $1.329^{\star \star}$ & -0.119 & -0.123 & -0.110 & -0.131 \\
\hline & & $(0.096)$ & $(0.094)$ & $(0.124)$ & $(0.093)$ & $(0.561)$ & $(0.560)$ & $(0.637)$ & $(0.556)$ & $(0.176)$ & $(0.171)$ & $(0.170)$ & $(0.180)$ \\
\hline & & 0.003 & 0.003 & 0.002 & 0.003 & 0.035 & 0.035 & 0.028 & 0.035 & -0.003 & -0.003 & -0.003 & -0.003 \\
\hline \multirow{3}{*}{$M_{P S} S_{t-1}$} & $0.188^{*}$ & $0.189 *$ & $0.190^{*}$ & $0.191^{*}$ & $0.179 *$ & $0.190^{*}$ & $0.191^{*}$ & $0.190^{*}$ & $0.179^{*}$ & $0.190^{*}$ & $0.190^{*}$ & $0.189 *$ & $0.178^{*}$ \\
\hline & $(0.088)$ & $(0.090)$ & $(0.090)$ & $(0.090)$ & $(0.087)$ & $(0.091)$ & $(0.091)$ & $(0.091)$ & $(0.088)$ & $(0.090)$ & $(0.090)$ & $(0.089)$ & $(0.087)$ \\
\hline & 0.050 & 0.051 & 0.051 & 0.051 & 0.048 & 0.051 & 0.051 & 0.051 & 0.048 & 0.051 & 0.051 & 0.050 & 0.048 \\
\hline \multirow[t]{3}{*}{$Y_{t-1} \times \Delta$ FARI_Shock t $_{t-1}$} & & & -0.019 & & & & -0.023 & & & & -0.020 & & \\
\hline & & & $(0.025)$ & & & & $(0.024)$ & & & & $(0.025)$ & & \\
\hline & & & -0.002 & & & & -0.003 & & & & -0.003 & & \\
\hline \multirow[t]{3}{*}{$Y_{t-1} \times M a P P \_S h o c k_{-t-1}$} & & & & 0.022 & & & & 0.105 & & & & -0.009 & \\
\hline & & & & $(0.025)$ & & & & $(0.073)$ & & & & $(0.012)$ & \\
\hline & & & & 0.006 & & & & 0.029 & & & & -0.002 & \\
\hline \multirow{3}{*}{$Y_{t-1} \times M P S_{t-1}$} & & & & & -0.003 & & & & -0.003 & & & & -0.003 \\
\hline & & & & & $(0.004)$ & & & & $(0.004)$ & & & & $(0.004)$ \\
\hline & & & & & -0.010 & & & & -0.009 & & & & -0.010 \\
\hline \multirow[t]{3}{*}{$\Delta^{4} F_{-} R G D P_{t-1}$} & 0.518 & 0.518 & 0.517 & 0.517 & 0.520 & 0.510 & 0.508 & 0.504 & 0.512 & 0.520 & 0.519 & 0.520 & 0.522 \\
\hline & $(0.415)$ & $(0.415)$ & $(0.414)$ & $(0.416)$ & $(0.411)$ & $(0.415)$ & $(0.414)$ & $(0.415)$ & $(0.411)$ & $(0.416)$ & $(0.415)$ & $(0.416)$ & $(0.412)$ \\
\hline & 0.067 & 0.066 & 0.066 & 0.066 & 0.067 & 0.065 & 0.065 & 0.064 & 0.065 & 0.067 & 0.066 & 0.067 & 0.067 \\
\hline \multirow[t]{2}{*}{ Constant } & -1.278 & -4.237 & -1.287 & -4.250 & -4.139 & -1.217 & -4.234 & -1.188 & -1.123 & -1.313 & -4.269 & -1.306 & -4.171 \\
\hline & (2.404) & (2.412) & $(2.437)$ & $(2.418)$ & $(2.363)$ & $(2.431)$ & (2.419) & $(2.426)$ & $(2.425)$ & (2.439) & $(2.425)$ & (2.435) & (2.373) \\
\hline Time-fixed Effect & Quarter & Quarter & Quarter & Quarter & Quarter & Quarter & Quarter & Quarter & Quarter & Quarter & Quarter & Quarter & Quarter \\
\hline Observations & 3,522 & 3,506 & 3,506 & 3,506 & 3,506 & 3,506 & 3,506 & 3,506 & 3,506 & 3,506 & 3,506 & 3,506 & 3,506 \\
\hline \# of Economies & 61 & 61 & 61 & 61 & 61 & 61 & 61 & 61 & 61 & 61 & 61 & 61 & 61 \\
\hline Overall R-square & 0.732 & 0.732 & 0.732 & 0.732 & 0.732 & 0.732 & 0.732 & 0.733 & 0.732 & 0.732 & 0.732 & 0.732 & 0.732 \\
\hline Within R-square & 0.637 & 0.637 & 0.638 & 0.638 & 0.638 & 0.638 & 0.638 & 0.638 & 0.638 & 0.637 & 0.638 & 0.638 & 0.638 \\
\hline
\end{tabular}

Source: Authors' calculations.

Note: (a) Standard errors in parentheses. ${ }^{* \star} p<0.01,{ }^{* *} p<0.05,{ }^{*} p<0.1$

(b) We drop Taiwan POC in the sample due to missing data of financial account restriction index.

(c) The blue italic numbers are standardized coefficients, representing the change of standard deviation in the dependent variable by one standard deviation change in corresponding independent variables.

(d) Both of the capital inflows and capital control measures are based on the gross other investment inflows. 


\section{4(c) The Random Effect Model with Macroprudential Policy Shocks and Capital Control Shocks}

\begin{tabular}{|c|c|c|c|c|c|c|c|c|c|c|c|c|c|}
\hline \multirow{3}{*}{ Variables } & \multirow{3}{*}{$\begin{array}{c}\text { Baseline } \\
\text { (1) } \\
\text { RE }\end{array}$} & \multicolumn{4}{|c|}{ iMaPP } & \multicolumn{4}{|c|}{ Borrower-based tools } & \multicolumn{4}{|c|}{ Financial institutions-based tools } \\
\hline & & (2) & (3) & (4) & $(5)$ & (6) & (7) & $(8)$ & (9) & (10) & (11) & (12) & (13) \\
\hline & & RE & RE & RE & RE & RE & RE & RE & RE & RE & RE & RE & RE \\
\hline \multicolumn{14}{|c|}{ The "Gates" Effect of Capital Controls + MaPP } \\
\hline \multirow[t]{3}{*}{$C F L O W \_D M_{t-1}$} & $0.732^{\star * *}$ & $0.732^{* * *}$ & $0.732^{* \star *}$ & $0.733^{* * *}$ & $0.733^{\star * \star}$ & $0.732^{* * *}$ & $0.732^{* \star *}$ & $0.732^{\star \star \star}$ & $0.733^{* * *}$ & $0.732^{\star * *}$ & $0.732^{* * *}$ & $0.732^{\star * *}$ & $0.732^{\star * *}$ \\
\hline & $(0.027)$ & $(0.027)$ & $(0.027)$ & $(0.027)$ & $(0.027)$ & $(0.027)$ & $(0.027)$ & $(0.027)$ & $(0.027)$ & $(0.027)$ & $(0.027)$ & $(0.027)$ & $(0.027)$ \\
\hline & 0.733 & 0.733 & 0.733 & 0.733 & 0.733 & 0.733 & 0.733 & 0.733 & 0.733 & 0.733 & 0.733 & 0.733 & 0.733 \\
\hline \multirow{3}{*}{$Y_{t-1}$} & $0.071^{\star * \star}$ & $0.071^{\star * *}$ & $0.071^{\star \star \star *}$ & $0.069^{\star * *}$ & $0.068^{\star \star \star}$ & $0.070^{* * *}$ & $0.071^{\star \star *}$ & $0.066^{\star \star \star}$ & $0.068^{* \star *}$ & $0.071^{\star \star *}$ & $0.071^{* * *}$ & $0.071^{\star * *}$ & $0.068^{\star * *}$ \\
\hline & $(0.020)$ & $(0.020)$ & $(0.020)$ & $(0.020)$ & $(0.022)$ & $(0.020)$ & $(0.020)$ & $(0.020)$ & $(0.022)$ & $(0.020)$ & $(0.020)$ & $(0.020)$ & $(0.022)$ \\
\hline & 0.059 & 0.059 & 0.059 & 0.057 & 0.057 & 0.058 & 0.059 & 0.055 & 0.056 & 0.059 & 0.059 & 0.059 & 0.057 \\
\hline \multirow[t]{3}{*}{$\Delta F A R I$ Shock ${ }_{t-1}$} & $-0.294^{*}$ & $-0.322^{\star *}$ & -0.286 & $-0.306^{* *}$ & $-0.319^{\star \star *}$ & $-0.337^{\star *}$ & -0.293 & $-0.369^{* *}$ & $-0.334^{* *}$ & $-0.268^{*}$ & -0.228 & $-0.279^{\star}$ & $-0.264^{*}$ \\
\hline & $(0.170)$ & $(0.160)$ & $(0.200)$ & $(0.147)$ & $(0.159)$ & $(0.161)$ & $(0.205)$ & $(0.161)$ & $(0.160)$ & $(0.159)$ & $(0.189)$ & $(0.170)$ & $(0.159)$ \\
\hline & -0.004 & -0.005 & -0.004 & -0.004 & -0.004 & -0.005 & -0.004 & -0.005 & -0.005 & -0.004 & -0.003 & -0.004 & -0.004 \\
\hline \multirow[t]{3}{*}{ MaPP_Shock $t_{t-1}$} & & 0.121 & 0.119 & 0.094 & 0.120 & $1.381^{\star \star}$ & $1.385^{\star \star}$ & $1.107^{*}$ & $1.381^{\star *}$ & -0.117 & -0.121 & -0.105 & -0.119 \\
\hline & & $(0.100)$ & $(0.098)$ & $(0.128)$ & $(0.100)$ & $(0.566)$ & $(0.564)$ & $(0.631)$ & $(0.566)$ & $(0.178)$ & $(0.173)$ & $(0.169)$ & $(0.181)$ \\
\hline & & 0.004 & 0.004 & 0.003 & 0.004 & 0.045 & 0.045 & 0.036 & 0.045 & -0.004 & -0.004 & -0.003 & -0.004 \\
\hline \multirow{3}{*}{$M P S_{-} D M_{t-1}$} & $0.164^{\star *}$ & $0.163^{* \star}$ & $0.163^{* *}$ & $0.164^{* *}$ & $0.161^{* *}$ & $0.164^{\star \star}$ & $0.164^{\star \star}$ & $0.165^{\star *}$ & $0.162^{\star *}$ & $0.163^{* *}$ & $0.163^{* *}$ & $0.162^{* *}$ & $0.161^{\star *}$ \\
\hline & $(0.071)$ & $(0.070)$ & $(0.070)$ & $(0.071)$ & $(0.071)$ & $(0.072)$ & $(0.072)$ & $(0.072)$ & $(0.073)$ & $(0.070)$ & $(0.070)$ & $(0.069)$ & $(0.071)$ \\
\hline & 0.033 & 0.033 & 0.033 & 0.033 & 0.033 & 0.033 & 0.033 & 0.033 & 0.033 & 0.033 & 0.033 & 0.033 & 0.033 \\
\hline \multirow[t]{3}{*}{$Y_{t-1} \times \Delta F A R I$ Shock $k_{t-1}$} & & & -0.017 & & & & -0.020 & & & & -0.018 & & \\
\hline & & & $(0.025)$ & & & & $(0.024)$ & & & & $(0.025)$ & & \\
\hline & & & -0.003 & & & & -0.003 & & & & -0.003 & & \\
\hline \multirow[t]{3}{*}{$Y_{t-1} \times M a P P \_S h o c k_{-t-1}$} & & & & 0.021 & & & & 0.106 & & & & -0.012 & \\
\hline & & & & $(0.024)$ & & & & $(0.072)$ & & & & $(0.012)$ & \\
\hline & & & & 0.007 & & & & 0.036 & & & & -0.004 & \\
\hline \multirow[t]{3}{*}{$Y_{t-1} \times M P S \_D M_{t-1}$} & & & & & -0.001 & & & & -0.001 & & & & -0.001 \\
\hline & & & & & $(0.003)$ & & & & $(0.003)$ & & & & $(0.003)$ \\
\hline & & & & & -0.003 & & & & -0.003 & & & & -0.003 \\
\hline \multirow[t]{3}{*}{$\Delta^{4} F_{-} R G D P_{t-1}$} & 0.250 & 0.252 & 0.251 & 0.252 & 0.252 & 0.246 & 0.245 & 0.244 & 0.247 & 0.254 & 0.253 & 0.253 & 0.255 \\
\hline & $(0.224)$ & $(0.225)$ & $(0.224)$ & $(0.225)$ & $(0.224)$ & $(0.225)$ & $(0.224)$ & $(0.226)$ & $(0.224)$ & $(0.225)$ & $(0.224)$ & $(0.225)$ & $(0.224)$ \\
\hline & 0.040 & 0.040 & 0.039 & 0.040 & 0.040 & 0.039 & 0.039 & 0.038 & 0.039 & 0.040 & 0.040 & 0.040 & 0.040 \\
\hline \multirow[t]{3}{*}{ Avg Credit/GDP } & 0.003 & 0.003 & 0.003 & 0.003 & 0.003 & 0.003 & 0.003 & 0.003 & 0.003 & 0.003 & 0.003 & 0.003 & 0.003 \\
\hline & $(0.003)$ & $(0.003)$ & $(0.003)$ & $(0.003)$ & $(0.002)$ & $(0.003)$ & $(0.003)$ & $(0.003)$ & $(0.002)$ & $(0.003)$ & $(0.003)$ & $(0.002)$ & $(0.002)$ \\
\hline & 0.012 & 0.012 & 0.012 & 0.012 & 0.012 & 0.011 & 0.011 & 0.011 & 0.012 & 0.012 & 0.012 & 0.011 & 0.012 \\
\hline \multirow[t]{2}{*}{ Constant } & -2.157 & -2.165 & -2.160 & -2.198 & -2.161 & -2.110 & -2.103 & -2.119 & -2.105 & -2.164 & -2.158 & -2.148 & -2.160 \\
\hline & (1.678) & $(1.685)$ & (1.681) & $(1.685)$ & $(1.692)$ & $(1.696)$ & $(1.692)$ & (1.699) & $(1.703)$ & (1.689) & $(1.685)$ & (1.671) & (1.696) \\
\hline Time-fixed Effect & Quarter & Quarter & Quarter & Quarter & Quarter & Quarter & Quarter & Quarter & Quarter & Quarter & Quarter & Quarter & Quarter \\
\hline Observations & 3,522 & 3,506 & 3,506 & 3,506 & 3,506 & 3,506 & 3,506 & 3,506 & 3,506 & 3,506 & 3,506 & 3,506 & 3,506 \\
\hline \# of Economies & 61 & 61 & 61 & 61 & 61 & 61 & 61 & 61 & 61 & 61 & 61 & 61 & 61 \\
\hline Overall R-square & 0.637 & 0.637 & 0.637 & 0.637 & 0.637 & 0.637 & 0.637 & 0.638 & 0.637 & 0.637 & 0.637 & 0.637 & 0.637 \\
\hline
\end{tabular}

Source: Authors' calculations.

Note: (a) Standard errors in parentheses. ${ }^{* *} p<0.01,{ }^{* *} p<0.05,{ }^{*} p<0.1$

(b) We drop Taiwan POC in the sample due to missing data of financial account restriction index.

(c) The blue italic numbers are standardized coefficients, representing the change of standard deviation in the dependent variable by one standard deviation change in corresponding independent variables.

(d) Both of the capital inflows and capital control measures are based on the gross other investment inflows. 
Figure 2. Credit-to-GDP Gap and Usage of iMaPP Actions (2000: Q1-2016: Q4, by Economy)

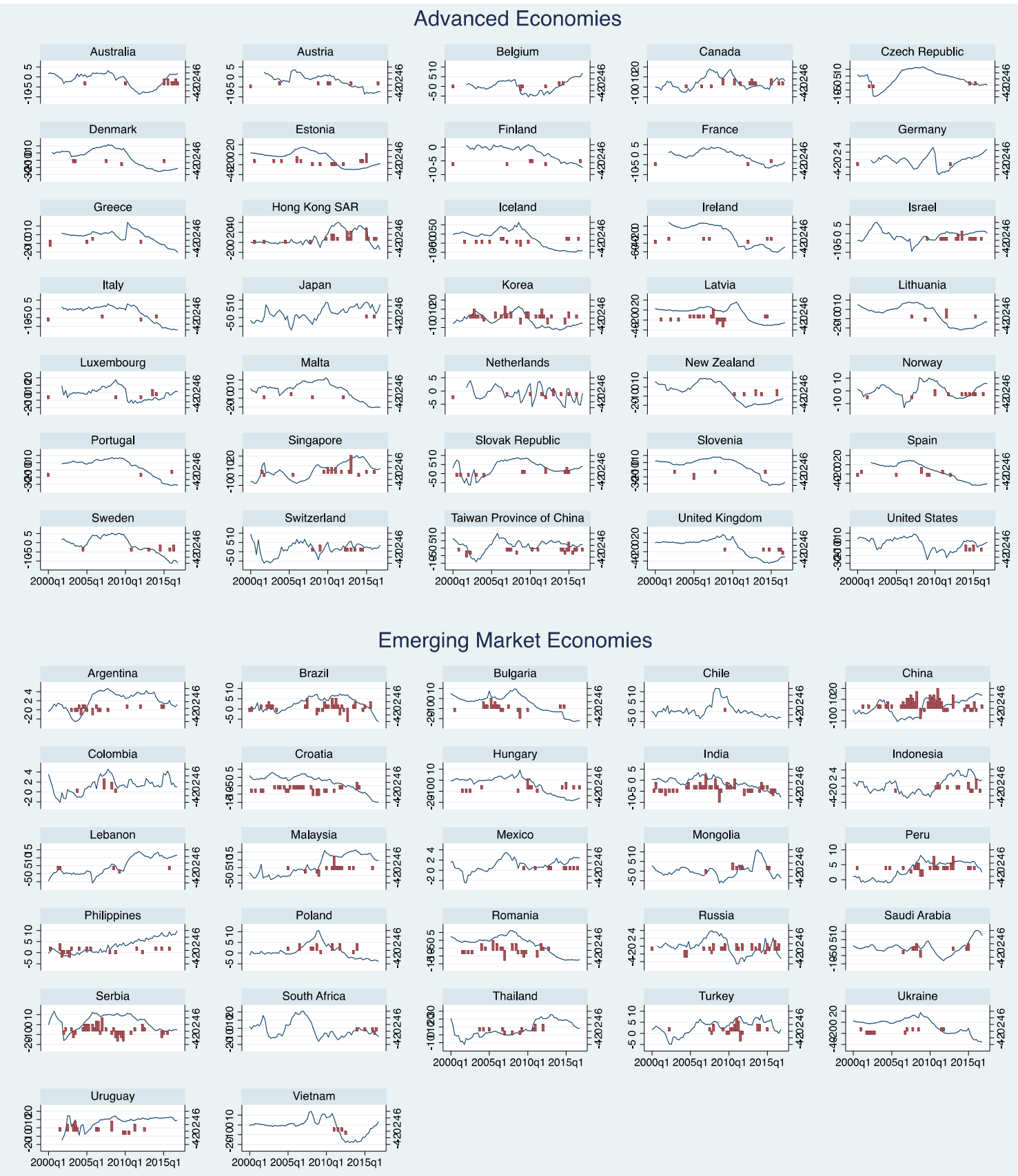

quarter

Credit-to-GDP Gap (left axis)

Usage of MaPP Actions (right axis)

Source: Authors' calculations.

Note: Country classification is based on the latest WEO. 
Figure 3. Number of Tightening and Loosening Macroprudential Policy Actions (2000: Q1-2016: Q5, All Sample Economies)

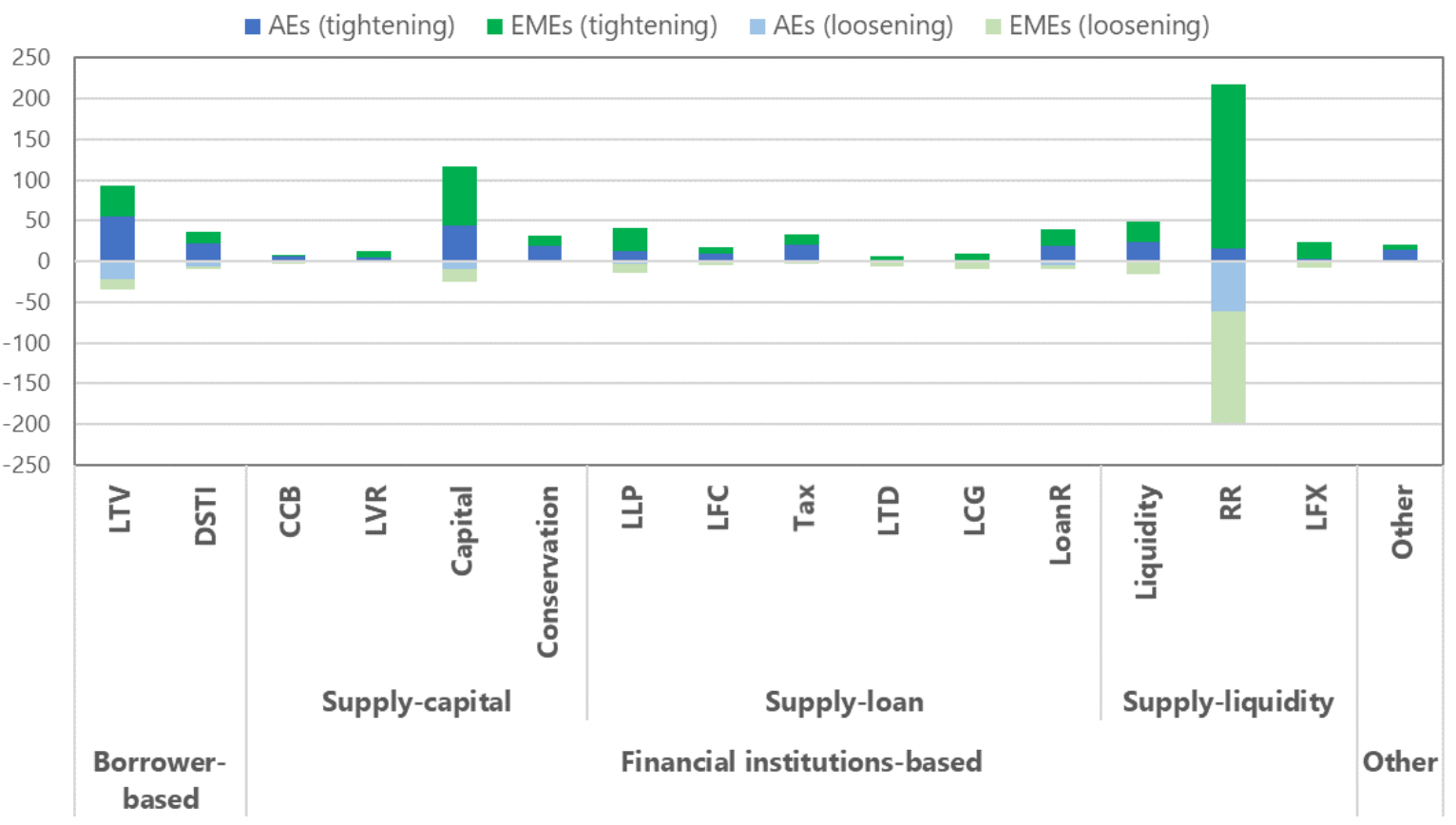

Source: IMF iMaPP Database, Alam et al. (2019), authors' calculations. Excluding SIFI from the original database.

Note: Country classification is based on the latest WEO. 